\title{
Nyéki Bence
}

\section{Denominális diminutívumképzés az orosz, német és magyar nyelvben*}

\begin{abstract}
Jelen dolgozatban az orosz, német és magyar denominális diminutívumképzést vizsgálom a morfológiai produktivitás és a szemantika szempontjából. Ez egy sajátos toldalékolás, melyet hagyományosan derivációnak szokás tekinteni. A dolgozat fő célja a három nyelv diminutívumképzése közötti hasonlóságok valamint különbségek feltárása. A kutatás részben nonszensz szavakat tartalmazó internetes kérdöíveken alapul. A diminutívumok, melyeket a válaszadók a nonszensz szavakból képeztek, nem mindig támasztják alá a szakirodalom alapján megfogalmazott hipotéziseket a deriváció szabályairól. Korpuszok tették lehetővé a produktivitás további vizsgálatát és a szubjektív-evaluatív szóképzési jelentés aktualizációinak megfigyelését. Látszólag „,a lehető legáltalánosabban vett kicsinyítés" az általános diminutívumjelentés legjobb meghatározása a három nyelv tekintetében. Az orosz képes a legtöbbféle realizációra, a német és magyar diminutívumképzés ebből a szempontból majdnem azonos szinten áll.
\end{abstract}

Kulcsszavak:

nyelvtudomány, diminutívum, szóképzés, produktivitás, szubjektív-evaluatív

\section{Denominale Diminutivbildung im Russischen, Deutschen und Ungarischen}

In der vorliegenden Arbeit wird die russische, deutsche und ungarische denominale Diminutivbildung hinsichtlich der morphologischen Produktivität und der Semantik untersucht. Es handelt sich um eine besondere Suffigierungsart, die üblicherweise als Derivation betrachtet wird. Das Hauptziel der Arbeit ist die Ermittlung der Ähnlichkeiten und Unterschiede in der Diminutivbildung der drei Sprachen. Der erste Teil der empirischen Untersuchung basiert auf Online-Fragebögen, die Kunstwörter enthalten. Die Diminutive, die von den Befragten aus den Kunstwörtern gebildet worden sind, bestätigen nicht immer die aufgrund der Fachliteratur formulierten Hypothesen über die Derivationsregeln. Die Untersuchung der Produktivität und die Beobachtung der Aktualisierung der subjektiv-evaluativen Wortbildungsbedeutung im zweiten Teil der Arbeit wurden durch Korpora ermöglicht. „Verkleinerung im allgemeinsten Sinne“ scheint die beste Bestimmung der generellen Diminutivbedeutung für die drei Sprachen zu sein. Das Russische weist die meisten Realisationsmöglichkeiten auf, während die deutsche und ungarische Diminutivbildung unter diesem Gesichtspunkt beinahe gleich sind.

Schlüsselwörter:

Sprachwissenschaft, Diminutiv, Wortbildung, Produktivität, subjektiv-evaluativ

\section{Bevezetés}

A diminutívumok kutatása az ókor óta foglalkoztatja a kutatókat. Ez nem is meglepő, tekintve, mennyire változatos jelenséggel van dolgunk. Látszólag viszonylag egyszerü körüljárni és megragadni a felmerülő problémákat, azonban a tények értelmezése rendkívül eltérő lehet. A következőkben kiválasztunk három nyelvet - az oroszt, a németet és a magyart

\footnotetext{
* Betreut wurde die Arbeit von Edit Dési und Rita Brdar-Szabó.
} 
-, melyekben a diminutívumok sok szempontból nagyon hasonló tulajdonságokkal rendelkeznek, és vizsgálatuk közben igyekszünk megállapítani, miben állnak ezek a hasonlóságok, esetleg a különbségek, elsősorban a képzés és a szemantika sajátosságaira összpontosítva. Fontos, hogy eleve produktívnak feltételezett szuffixumokat fogunk összehasonlítani (vö. Lopatyin 1982: 208-216, Fleischer/Barz 2012: 231-235, Kiefer/Ladányi 2000b: 168-170). A lexikalizálódott kicsinyítő képzős szavakkal, illetve a nem termékeny derivációs szabályokkal ${ }^{1}$ külön nem foglalkozunk.

Mi is azonban a diminutívum? Hentschel és Weydt (2013: 181) említi, hogy a terminus a latin deminuere ,csökkent, kicsinyít' igére vezethető vissza. Egyesek ettől elválasztják a görög „hypokoristikon” fogalmat, mely a nyelvre vonatkoztatva hasonló jelenséget jelöl, nevezetesen egyfajta modifikációs szóképzéssel kapcsolatos kategóriát, csak éppen szubjektív szemszögből megközelítve (Delhay 1995: 70). A magyarban a morfológiai szemléletet tükröző „kicsinyítő képző” kifejezés terjedt el. A németben egész szavakt értünk a „Diminutiv/Diminutivum” mellett használatos „Verkleinerungsform” alatt, sőt érdekes módon e terminus azt sugallhatja, hogy valójában nem önálló lexémákról, hanem szóalakokról van szó (a deriváció és inflexió problémáját röviden megemlítjük a 2. fejezetben). Az oroszban pedig a szemantikából kiindulva kicsinyítő, becéző és lenéző jelentést tartanak számon (,уменьшительное”, „ласкательное”, „уничижительное значение”). Mi a továbbiakban a „diminutívum” elnevezéshez ragaszkodunk, ami alatt derivátumokat értünk.

A dolgozat címében „denominális” diminutívumképzés szerepel. Előfordulhat olyan deverbális deriváció is, amely az alapszó által kifejezett cselekvés intenzitásának csökkenését fejezi ki, ami hasonlít a diminutívum funkciójához (pl. német lachen > lächeln), ezzel azonban nem foglalkozunk a következőkben. Az is világossá válik majd, hogy mind a bázis, mind a diminutívum az esetek döntő többségében főnév. Ezért vizsgálódásunkat a deszubsztantivális képzések körében folytatjuk, ettől eltérő jelenségekről jelen munka keretein belül elegendő lesz csak említést tenni.

A dolgozat a következőképpen épül fel: először a morfológiai leírásokat és az ezek kapcsán felmerülő problémákat érintjük, majd empirikus adatokkal (internetes korpuszok, kérdőívek) ellenőrizzük feltételezéseink helyénvalóságát. Bár munkánk alapvetően szinkrón nézőpontú, a 3. pontban rövid történeti kitekintésre vállalkozhatunk. Ennek célja olyan tényezők feltárása,

\footnotetext{
${ }^{1}$ Általában nem meghatározott affixumok, hanem szóképzési minták vagy szabályok produktivitásáról szokás beszélni (lásd pl. Dressler/Ladányi 2000, Kiefer/Ladányi 2000a, Ladányi 2007). Az, hogy pontosan miképpen használjuk a terminusokat, függhet attól, hogy milyen elméleti álláspontot foglalunk el a szóképzésről mint nyelvi jelenségről. Bár munkánk több pontján támaszkodhatunk majd a természetes morfológia elvi kereteire, nem tartjuk magunkat szigorúan a „,valamely derivációs szabály produktivitása” kifejezésmódhoz. Ennek megfelelőjeként fogjuk értelmezni valamely affixum produktivitását.
} 
melyek a tanulmányozott képzők produktivitásáról alkotott képet támaszthatják alá. Végül elérkezünk a szemantikai és pragmatikai vizsgálathoz. Kísérletet teszünk annak megértésére, milyen jelentések vagy funkciók tartoznak e két területhez, bár tökéletes elhatárolásukra nem vállalkozhatunk. Az egyes jelentéseket korpuszokból vett példamondatok támasztják alá. $\mathrm{Az}$ idegen nyelvű példamondatok és szakirodalmi idézetek fordítását lábjegyzetben közlöm. A fordítás minden esetben tőlem van.

Elöljáróban még le kell szögeznünk, hogy a három nyelv összehasonlítása során elkerülhetetlenül olyan eredményekre jutunk majd, melyek szerint az egyik nyelvben a diminutívumképzők produktívabbak, gyakoribbak, több jelentésben/szituációban stb. használatosak, mint valamely másikban. Ez azonban nem jelenti azt, hogy valamelyik nyelv kevésbé lenne képes az adott jelentés kifejezésére. Ez ugyanis történhet analitikus módon is, tehát például jelzők vagy határozók használatával. Kutatásunk tárgya azonban a szintetikus eszközök megfigyelése.

\section{A diminutívum morfológiája}

A diminutívumok az orosz, német és a magyar nyelvben egyaránt derivátumokként állíthatók elő a megfelelő szuffixumok használatával, vagyis képzésükre rendelkezésre állnak szintetikus eszközök. Mindhárom nyelvben több képző szolgálhatja ezt a célt. Ahhoz, hogy ezeknek működését megérthessük, szükségünk van a diminutívum általános jelentésének ismeretére. Ennek meghatározására a szemantikával, illetve kisebb részben pragmatikával foglalkozó fejezetben fogunk kísérletet tenni. Egyelöre elégedjünk meg annyival, hogy valamilyen szó szerinti vagy átvitt értelemben vett kicsinyítés jut kifejezésre. Ebben a fejezetben morfológiai problémákat, elsősorban a szuffixumok produktivitását tartjuk szem elött.

Elözetesen azonban meg kell jegyeznünk, hogy kutatásunk tárgyára pusztán a hagyománynak megfelelően használjuk a „képző” terminust. Zsemlyei (2011: 31-34) kifejti, hogy a diminutívumokat létrehozó toldalékok részben inflexiós jegyeket mutatnak, így átmeneti jelenséggel van dolgunk. Ez az érvelés meggyőző, de lényegében nem befolyásolja munkánkat. Zsemlyei magát a toldalékot nevezi diminutívumnak, itt ezt a kifejezést a „kicsinyítő toldalékkal” ellátott szavakra (nevezzük őket derivátumoknak vagy származékoknak) tartjuk fenn. 


\subsection{Az orosz, német és magyar diminutívumképzők}

Alaktanilag viszonylag könnyen leírhatónak tünnek a diminutívumok, azonban itt is több problémával találjuk szemben magunkat. Felmerül például az az elméleti kérdés, hogy mely morfokat tekintsük allomorfoknak. E munka keretein belül nincsen módunk kidolgozni azokat az elveket, amelyek egyértelmủen irányt mutatnának a csoportosítás során. Fogadjuk el most egyszerüen a következőket:

a) Az orosz nyelvben számos szuffixum segítségével hozható létre diminutívum, ráadásul bizonyos esetekben még az sem nyilvánvaló, diminutívumképzőről vagy más modifikációs típushoz tartozó morfémáról van-e adott esetben szó. A továbbiakban az „Orosz nyelvtan I. Főnévképzés” címü fejezetének (Lopatyin 1982: 208-216) leírásából indulunk ki, és amit ott egy képzőnek számítanak, azt tekintjük egy morfémának, pl. -ок/-ик/-чик, -к(a)/-очк(a), -к(o)/-ьıшк(o)/-ечк(o), hangsúlytalan -yuк- stb.

b) A németországi német köznyelvben két produktív diminutívumképző szuffixumot találunk: ezek a -chen és a -lein.

c) A magyarban $-k A$ morfémáról beszélhetünk -ka és -ke allomorfokkal, illetve - $(V) c s k A$ morfémáról -cska, -acska, -ocska, -cske, -ecske, -öcske allomorfokkal.

Tekintsük át röviden, melyek azok a képzési szabályok, amelyek elméletileg meghatározzák az egyes morfémák, illetve allomorfok előfordulását.

Az orosz diminutívumképzőkről részletes leírást ad a már említett „Orosz nyelvtan I.” fent említett fejezete (Lopatyin 1982: 208-216), most ennek alapján vesszük sorra a legfontosabb megállapításokat. Értékes példákat ad meg továbbá a „Rövid orosz nyelvtan” (Svedova/Lopatyin 1989: 68-70). A képzésben nagyon fontos szerepet játszik a nyelvtani nem. A diminutívumképzés során a bázis genusa többnyire változatlan marad, bár vannak kivételek, pl. тень > тенёк. Jellemzően hímnemü bázisokhoz járul az -ок(/-ек)/-ик/-чик vagy az -eu képző, nőnemüekhez a $-\kappa(a) /-о ч \kappa(a), \quad-u u(a)$, semlegesnemüekhez a $-\kappa(o) /-b \iota u \kappa(o) /-е ч \kappa(o),-u(o) /-e u(o) /-u(e) /-u u(e)$. Emellett számos más, kevésbé gyakran előforduló képző létezik, melyek közül némelyik „kétarcú”, mint az -ишк- és az -оньк-. A velük képzett derivátumok a bázistól függően hím- vagy nőnemüek. A relatív tő utolsó mássalhangzója váltakozást mutathat, különösen jellemző ez a velárisokra (pl. волк > волчок). A tő csonkítása ugyancsak elöfordulhat: плотва $>$ плотица, пальто $>$ пальтецио. Egyes képzőkhöz - különösen a nyelvtörténeti szempontból összetett szerkezetűekhez domináns (bár nem kizárólagos) jelentés vagy konnotáció kapcsolódhat, pl. az -uuкsegítségével létrehozott derivátumokra jellemző a lenézés kifejezése. Nem ritka jelenség a képzők halmozása sem, ilyenkor a szubjektív jelentés (mellyel a beszélő személyes attitűdjét 
jelzi) nyomatékosítására kell számítanunk: дуб > дубок $>$ дубочек, сестра $>$ сестрий $>$ сестричка, окно > окошко > окошечко.

Meg kell jegyeznünk, hogy a produktív deadjektivális -оньк-/-еньк- melléknévképzők funkciójukban nagyon hasonlítanak a diminutívumok szuffixumaihoz, melyek fönevekhez járulnak. Nem egyértelmű azonban, helyes-e olyan melléknévi derivátumokat diminutívumoknak nevezni, mint а молоденький, глупенький. Utóbbiakkal alapvetően szubjektívevaluatív tartalom juttatható kifejezésre (erről részletesen a 4.1. és a 4.2. pontban szólunk), míg a főnévi diminutívumok ennél változatosabb jelentésekkel rendelkeznek, ráadásul képzésükhöz számos különböző morféma közül válogathatunk. Így ha beszélhetünk is az oroszban melléknévi diminutívumokról, azokat különálló kategóriaként kell kezelnünk, amelyekre nem csak mondattanilag vonatkoznak más szabályok, mint a „kicsinyített” fönevekre.

A német két tipikus diminutívumképzője a -chen és a -lein. Hentschel és Weydt (2013: 182) említ továbbá néhány dialektushoz kötődő szuffixumot, ilyen a -le, -el, -erl, -li, - $(s) k e n$. Fleischer és Barz (2012: 234) megjegyzi, hogy az -el morf a standard írott nyelvben is előfordul (Haarbüschel, Krümel), habár csak néhány meghatározott lexémában. Azt is említik, hogy néha -elchen összetett diminutívumképzöre bukkanhatunk, pl. Büchelchen, Löchelchen, Wägelchen. A németben más módja nincs a diminutívumképzők halmozásának. További érdekesség a gyermek- és ifjúsági nyelvre korlátozódó, becéző szerepü - $i$ szuffixum (pl. Dummi); az ezzel képzett szavak szerkezetét a gyermekek sokszor nem is látják át, mintegy lexikalizálódott származékokként jelennek meg számukra (Dressler/Merlini Barbaresi 1994: 105-106). Visszatérve a -chen és -lein szuffixumokra, a bázis grammatikai neme nem korlátozza előfordulásukat, a származékok pedig mindig semlegesneműek. A diminutívumképző néha többes számú főnévhez is kapcsolódhat, ha az -er-re végződik, pl. Dingerchen, Kinderchen. A -lein délnémet, míg a -chen északi eredetü, ami származásuk szerint meg is mutatkozhat egyes írók müvein. A fonológiai környezet olykor meghatározhatja valamelyik képző használatát, de lényegében megfigyelhető a két képző konkurenciája. Szemantikai különbség nagyon ritkán adódik, mint a Frauchen (,háziállat női gazdája’) és Fräulein (,kisasszony’) esetében (Fleischer/Barz 2012: 232-233).

A magyar $-k A$ és $-(V) c s k A$ morfémákról Kiefer és Ladányi (2000b: 168-170) ír, az „Új magyar nyelvtan” (É. Kiss/Kiefer/Siptár 2003: 236-237) voltaképpen ugyanazokat az állításokat erősíti meg. Leszögezik, hogy az alacsonyka, szépecske, aprócska melléknevek létezése ellenére a szuffixumok csak fónévi alapszavakon produktívak. A $-k A$ képzőt több hangtani megkötés korlátozza, míg a $-(V) c s k A$ szabadon alkalmazható. Ennek alapján az 
utóbbit vélik termékenyebbnek. A magyarban találkozhatunk még az -i becézőnévképzővel, mely jellegzetesen csonka tövekhez járul: Peti, Zsuzsi, hasonlóképp: csoki, fagyi. Az -i megtalálható gyermeknyelvi testrészmegnevezésekben is. E képző után kapcsolható további - $k A$ morféma: Andika, csokika, lábika. Így nincs szükség önálló -ikA szuffixumot bevezetni (Kiefer/Ladányi 2000b: 170-172). Keszler (2000: 316-318) nem tesz különbséget kicsinyítő és becéző képzők között, közös csoportjukba a következőket sorolja: -cska/-cske, -ka/-ke, -i, -csi, -ca, -ci, -u, -us, -ikó, -csa/-cse, -kó, -is, -ó/-ö, -dad/-ded. Mindazonáltal csak a -cska/-cske, -ka/-ke és -i szuffixumokat tekinti termékenynek. A következőkben vizsgálatainkat az előbbi kettőre szükítjük.

\subsection{A szóképzési szabály produktivitása idegen szavakra alkalmazva}

Tömören összefoglaltuk tehát a három vizsgált nyelv legfontosabb képzési jellegzetességeit. Ahhoz, hogy többet tudjunk meg a diminutívumok morfológiájáról, érdemes kutatásokat végezni a produktivitás terén. A következőből kell kiindulnunk: „Valamely szóalkotási minta csak akkor termékeny, ha vele az adott szemantikai, szintaktikai és morfológiai feltételek mellett új szavak képezhetők" (Kiefer/Ladányi 2000a: 149). Természetesen számukban nem korlátozott és átlátható struktúrájú potenciális szavakról van szó. Ennek mérésére a természetes nyelvelmélet kidolgozott módszert kínál, ahogy azt Dressler és Ladányi (2000: 119-127) vagy Ladányi (2007: 47-51) kifejti. Ha tehát valamilyen derivációs morféma produktivitását kívánjuk meghatározni, meg kell vizsgálnunk, létrehozhatók-e a segítségükkel derivátumok a következő szinteken: 1. a nyelvbe nem illeszkedő bázisból a nyelvi rendszernek megfelelő származék képzése; 2. az átvevő nyelvi rendszerbe illeszkedő idegen szavakon való alkalmazhatóság; 3. rövidítések; 4. elmozdulás egy képzési alosztály felé (egyik affixum lassan kiszoríthatja a másikat); 5. a nyelv további szavai. Koncentráljunk most az első három kategóriára. Ha találunk megfelelő diminutívumokat, akkor az a képzők jelentős produktivitásáról fog tanúskodni.

Előfordulhat ugyan, hogy idegen diminutívum kerül be a nyelvbe (ezek leginkább szakkifejezések, pl. orosz органелла, német Organell ,sejtszervecske’), ezek azonban a beszélők számára nem érzékelhetők derivátumokként, nem kapcsolódnak tehát az 1. kritériumhoz. Megesik azonban az is, hogy egy az átvevő nyelvben már meglévő diminutívumképző segítségével illeszkedik be egy idegen szó az adott nyelvi rendszerbe. Ilyen lehet az orosz пальтецио (,kabát+DIM'), amelynek bázisa, a пальто nem ragozható fónév, ellentétben a származékkal, mely tehát jobban megfelel az orosz szavak morfológiai sajátosságainak. Ugyanez figyelhető meg a джерси > джерсишка szavaknál. Párhuzam vonható a Dressler 
és Ladányi (2000: 119) által bemutatott példával: a franciából átvett, oroszba nem jól illeszkedő шоссе (,országút') főnévből szabályos шоссейный melléknév és шоссировать ige képezhető. E felfogás alapján ide sorolhatjuk a német Restaurant $>$ Restaurantchen derivációt is, amennyiben az alapszó végén a német fonetikában idegen nazális magánhangzó áll: [restorã]. Dressler és Ladányi (2000: 120) feltevése, mely szerint minden idegen tőből képzett szó megfelel az átvevő nyelv fonológiai és fonetikai jellemzőinek, azt sugallja, hogy a fent említett Restaurantchen derivátumban az [ã] [a $+\mathrm{n}]$ hangokra bomlik.

A nyelvben már gyökeret vert, ahhoz alkalmazkodott jövevényszóhoz gyakrabban járulhat kicsinyítő képző. A vizsgált nyelvekben 100-100 idegen főnév lehetséges diminutívumainak előfordulását ellenőriztem az Orosz Nyelv Nemzeti Korpuszának (mostantól az angol elnevezés rövidítését használom: Russian National Corpus: RNC 2003-2016) alapkorpuszában, a COSMAS II (2016) rendszerében elérhető írott nyelvi archívumban (W Archiv der geschriebenen Sprache), illetve az MNSZ2 (2016) adatbázisában. ${ }^{2}$ (A termékenység 1 . és 2. szempontját ezúttal nem különítettem el; hogy részben a szókincs legújabb elemeit is ellenőrizhessem, olyan alapszavakat sem mellőztem a keresés során, melyek hangtanilag vagy alaktanilag nem teljesen integrálódtak az átvevő nyelvbe.) Az alapszóként kiválasztott szavak megtalálhatók „A mai orosz nyelv idegen szavainak szótára” (Jegorova 2014), „Az idegen szavak nagy szótára” (Baer/Wermke 2000), illetve az „Idegen szavak és kifejezések szótára” (Bakos 2013) címü szótárakban. Olyan bázisokból igyekeztem kiindulni, melyeket saját nyelvi kompetenciám alapján a mai mindennapi nyelvhasználatban viszonylag gyakorinak ítéltem. Lássuk mindazokat a derivátumokat, melyekre az internetes korpuszok jeleztek találatokat, majd példaképp említsünk meg olyan bázisokat is, melyek diminutívumaira nem volt példa (zárójelben a releváns találatok száma szerepel):

a) Orosz: банда > бандочка (2), бизнесмен > бизнесменчик (1), бутон > бутончик (48), джерси > джерсишка (1), джинсы > джинсики (29), джип > джипик (2)/джипчик (2), космонавт > космонавток (1), офшор > офиорчик (1)/ мини-офшорчик (1), партикмахер > парикмахеришка (1), революиионер > револючионеришка (2), режим > режимчик (2), рельс > рельсик (2), реферат > рефератик (10), свитер > свитерок (102)/свитерочек (14)/свитеришко (1), сувенир > сувенирчик (41), татуировка > татуировочка (3), файл > файлик (12), флакон > флакончик (376), экран > экранчик (82), хит > хиток (1), экскаватор > экскаваторишко (2), этикетка > этикеточка (6)

\footnotetext{
${ }^{2}$ A tanulmányban feltüntetett összes adatot, mely valamilyen korpuszból származik, 2016 novemberében és decemberében értem el.
} 
b) Német: Bonbon > Bonbönchen (29)/Bonbonchen (1), Boss > Bosschen (4), Clown > Clöwnchen (3)/Clownchen (1), Computer > Computerchen (16)/Compüterchen (2)/ Computerlein (1), Etikett $>$ Etikettchen (10), Friseur $>$ Friseurchen (1), Handy > Handylein (1), Mail > Mailchen (1), Manager > Managerlein (2), Pony > Ponychen (2), Star > Starchen (2)/Starelein (1), Restaurant > Restaurantchen (1), Revolver > Revolverchen (1), Souvenir > Souvenirchen (3)

c) Magyar: bravúr > bravúrocska (1), e-mail > e-mailke (1) klip > klipecske (8), klub > klubocska (5), kontó > kontócska (1), lord > lordocska (2), lady > ladyke (6)/lédike (1), fájl > fájlocska (40), frizura > frizurácska (1), paletta > palettácska (1), póni > pónika (1), pub > pubocska (1), rekord > rekordka (1), revolver > revolverecske (1), szpíker/speaker > speakerke (4)/speakerecske (2)/szpíkerke (1), sztár > sztárocska (183)

Alapszavak, amelyekhez nem tartozott diminutívum:

а) Orosz: адвертайзинг, андеграунд/андерграунд, апартаменты, астронавт, аэробика, байк, байкер, бизнес, бойфренд/бой-френд/бой-фрэнд, браузер/брозер, бренд/брэнд, брокер, ваучер, веб/вэб, веб-сайт/вэб-сайт, гений, дансинг, дартс, девайс, дедлайн, декольте, дефолт, джентльмен, джин, джокер, дизайн, дилер, имидж, имплантат, интернет, киборг, киллер, клише, компьютер, комфорт, консервант, консервы, консорицим, контокоррент, коррекция, лапmon/лэптоп/лэn-топ, лейбл/лэйбл, лидер, лобби, лорд, менеджер, митинг, овертайм, паб, пазл, пейнтбол/пэйнтбол, пони, резюме, рекорд, ремейк/римейк, ремикс, репертуар, ресурс, рефери, сальдо, сальто, скутер, спикер, старт, тинейджер/тинэйджер, уик-энд/уикэнд/уикенд, федерация, фидбэк, фишбургер, фрик, фрикаделька, хайвей, хай-тек, хепи-энд/хэпи-энд, хобби, шейкер, шопинг, moy

b) Német: Accountant, Advantage, Advertising, Appartement, Astronaut, Band, Bouton, Box, Boy, Boyfriend, Brainstorming, Bravour, Bridge, Browsing, Business, Businessman, Cash, City, Clip, Coach, Crew, Croissant, Cup, Cyborg, Dancing, Date, Deal, Dealer, Dresseur, File, Freak, Frikandeau, Gin, Girl, Goal, Handicapper, Handout, Highlight, Hit, Hobby, Implantat, Item, Jazz, Job, Jumper, Klischee, Klub/Club, Konto, Kosmonaut, Lady, Laptop, Leader, Lobby, Lodge, Look, Lord, Lounge, Mausklick/Mouseklick, Meeting, Mirage, Mix, Mouse, Newcomer, Palette, Pool, Power, Regime, Resource, Review, Saldo, Salon, Scooter, Screen, Shake, Share, Shirt, Shop, Shopping, Show, Sweater, Ticket, Wear, Website, Weekend, Wellness, Workshop 
c) Magyar: account, apartman/appartement, asztronauta, blazer/blézer, bonbon, boss, boy, branch, bridzs, bróker, browser, business, businessman, burzsoá, buton, cash, city, croissant, cup, dancing, deadlock, dealer, default, device, dzsörzé/jersey, fashion, favorit, feedback, fellow, firma, flakon, frikandó, fritz, görl, hacker, handout, hendikep, hit, hobbi, holding, implantátum, jumper, karosszéria, kiborg, killer, kioszk, klisé, komputer, konszern, kozmonauta, leader, lobby, lózung, meeting, menedzser, mikszer, mountainbike/mountain bike, office, off-shore, pool, popcorn, puzzle, referátum, referendum, repertoár, review, rezümé, rezsim, scooter, screen, shake, shaker, shop, show, szpícs, szaldó, szalon, szuvenír/souvenir, team, tikett, underground, víkend, vócser/voucher, workshop

A fenti adatokból természetesen nem szabad messzemenő következtetéseket levonni, hiszen mindhárom esetben önkényesen kiválasztott szavakat láthatunk, amelyek ráadásul eltérő eredetűek (bár többségében modern, angolból átvett szavak kerültek fel a listára, találunk például francia vagy latin eredetüeket is köztük; utóbbiakat nem napjainkban kölcsönözték az átvevő nyelvek). Mindazonáltal azt kijelenthetjük, hogy mindhárom nyelvben képezhető diminutívum idegen szóból, a legkönnyebben az oroszban megy végbe ez a folyamat. Ebben a nyelvben a -чик morf fordult elő leggyakrabban (bár ennek oka egyszerüen az lehet, hogy számos tő szonorhangra végződik, melyek után jellegzetesen ez a morf jelenik meg), de meglepően sokszor találkozunk az -uшк-képzővel is. A németben a -chen egyértelmüen produktívabbnak tünik, mint a -lein. Az umlaut gyakran elmarad. A magyarban az idegen bázisokon a $-(V) c s k A$ termékenyebb, mint a $-k A$. Igaz ugyan, hogy számos felsorolt szó nagyon ritkán jelenik meg a korpuszokban, mégsem kell figyelmen kívül hagynunk őket. Ezek erősen expresszív alakok, ami tökéletesen összefér a diminutívumok lehetséges jelentéseivel. A kontrasztív elemzéshez pedig vegyük szemügyre a következő diagramot: 


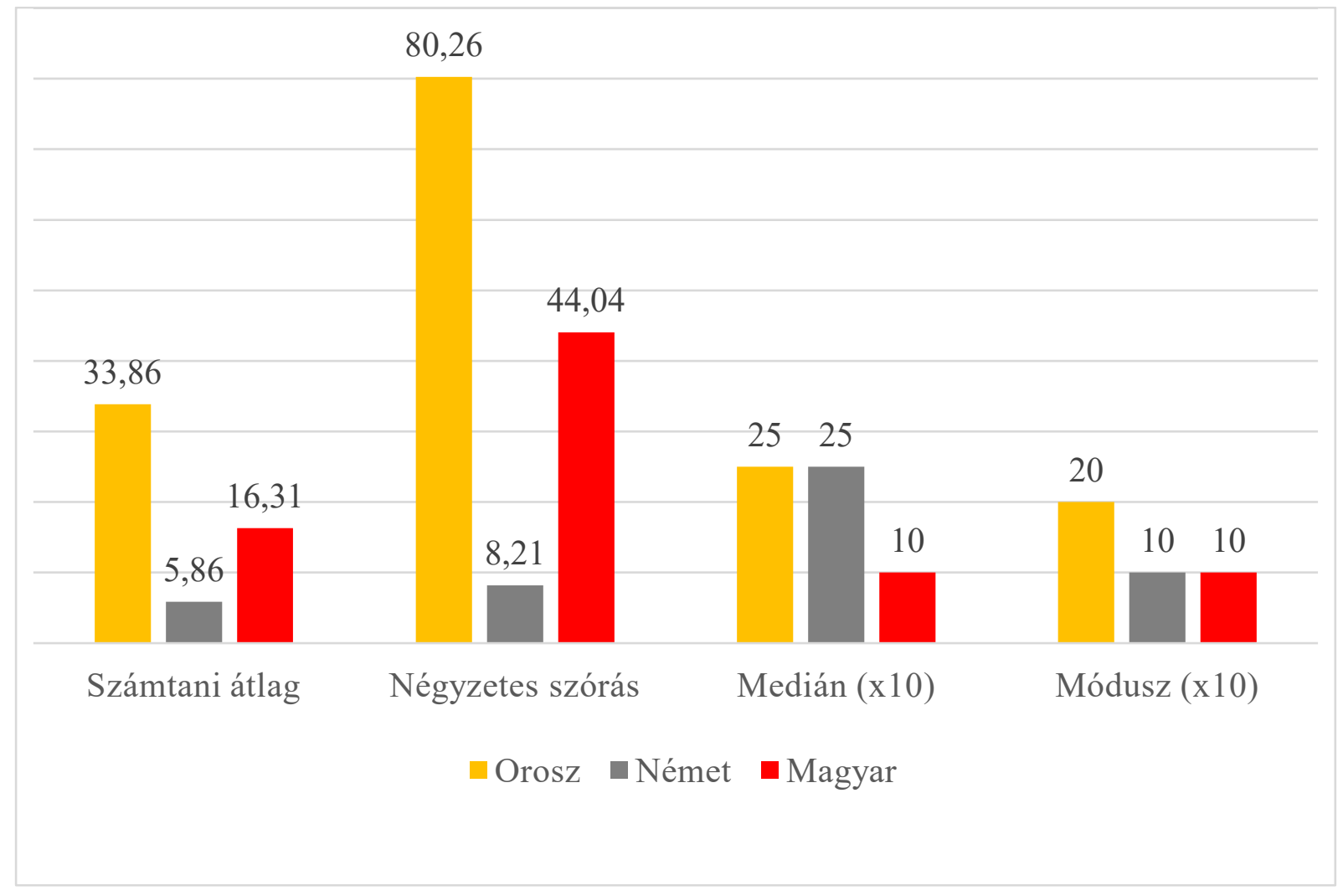

1. ábra. Statisztikai adatok idegen szavakból képzett diminutívumok korpuszokban való megjelenéséről.

Az adatok azt mutatják, átlagosan hány találatot jeleztek az egyes korpuszok az idegen szavakból képzett diminutívumokra (azon 22 orosz, 16 magyar és 14 német lexémához tartozó derivátumokat figyelembe véve, melyek legalább egyszer megjelentek a megfelelő szövegtárban). A számtani átlag és a négyzetes szórás nagy eltéréseit olyan elemek magyarázzák, mint a 376-szor előforduló флакончик. A módusz és a medián (a diagramon való láthatóság végett számértéküket 10-es szorzóval láttam el) mindazonáltal megbízhatóbban tanúskodik arról, hogy az idegen eredetü lexémákból alkotott kicsinyítő képzős származékok az oroszban tünnek a leginkább megszokottnak. A magyarban és a németben hasonló mértékben bukkannak fel, vélhetően speciálisabb kontextusban, nemegyszer nagyobb expresszív erővel, mint a velük összevetett orosz diminutívumok.

Ami a rövidítéseket, betűszavakat illeti, elvétve bukkanhatunk diminutívumképzőkre. Az RNC például releváns találatokat mutat а вузик, колхозик, совхозик szavakra (az internetet böngészve olyan különös derivátumokkal is találkozhatunk, mint a ДТП betüszóból képzett дэтэпэика), Google-kereséssel pedig Azubichen, Azubilein, PKWchen, PKWlein diminutívumokra láthatunk példát. Ladányi (2007: 156) említi a következőket: kft-cske, tsz-ecske, sztk-cska, maszekocska. 


\subsection{Adatgyưjtés és -elemzés: kérdőívek nonszensz szavakkal}

A diminutívumok alaktani jellemzőinek további kutatásához tanulságos lehet más empirikus adatokat is felhasználni. Orosz, német és magyar anyanyelvi beszélők számára egy-egy nonszensz szavakat tartalmazó anonim kérdőívet állítottam össze (több válasz nyerése érdekében az oroszoknak szánt eredeti kérdőívet célszerü volt rövidíteni és két részre osztani, így e nyelvet tekintve három, összesen öt ürlap készült). ${ }^{3}$ A terjesztés Google-ürlapok segítségével, az interneten keresztül zajlott. A német képzők kutatására szánt kérőívet 78-an töltötték ki. A válaszadók (nők és férfiak egyaránt) kb. 71\%-a berlini lakos, közülük mindössze öten 25 éven aluliak. Ami az orosz anyanyelvi beszélöket illeti, összesen 88 kitöltött kérdőív jutott el hozzám. Többségben voltak a 25 év feletti női válaszadók. Települést tekintve szentpéterváriak nyújtották a legnagyobb hozzájárulást (43\%). Magyar anyanyelvüektől 287 értékelhető visszajelzést kaptam. A kitöltőknek valamivel több mint fele már betöltötte 25 . életévét, $60 \%$-uk nö, $53 \%$-uk budapesti lakos.

A megkérdezettek a fiktív főnevekből diminutívumokat képeztek, így visszajelzésünk lehet arról, vélhetően mennyire helytállóak a szakirodalomban feltételezett hangtani korlátozások. Ez nem egészen független a produktivitás mérésétől: „A morfológiai termékenység nonszensz szavakkal is tesztelhető, ebben az esetben természetesen csak a toldalékolás produktivitása vizsgálható, a szemantikai kompozicionalitás nem jöhet szóba” (Kiefer/Ladányi 2000a: 149). Megesett, hogy néhány válaszadó csak képzőket adott meg, nem teljes derivátumokat. Ezeket figyelembe vettem, ha csupán egy adott morféma vagy morf előfordulásáról volt szükség információra, de a tő változásait vagy épp változatlanságát jelző adatokba nem számítottam őket bele. A teljes szavak közül csak a helyesen leírtakat tartottam szem elött (ha tehát a tövet vagy akár a toldalékot furcsa, ésszerűen nem értelmezhető változás érte, a szót minden számításban figyelmen kívül hagytam). Mivel a kérdőívekben kértem a kitöltőket, hogy mindig egy-egy képzett szót adjanak meg, az értékelés során ugyancsak mellőztem az egy bázishoz több származékot feltüntető válaszokat. Mielőtt azonban rátérnénk az eredmények értékelésére, lássuk a szakirodalom alapján felállítható hipotéziseket, itt említve azokat a fonológiai környezettel kapcsolatos korlátozásokat is, melyekre korábban már utaltunk.

\footnotetext{
${ }^{3}$ A válaszokat lásd a mellékletben. 


\subsubsection{Hipotézisek}

\subsubsection{Orosz}

A következő megállapítások alapja az „Orosz nyelvtan I.” „Főnévképzés” címü fejezetének (Lopatyin 1982: 208-216) idevágó leírása.

\subsection{Hímnemü főnevek}

I. A következő szabályok vonatkoznak az -oK/-ёк morf megjelenésére:

a) Magánhangzó+mássalhangzó, szonorhang+mássalhangzó, alveoláris réshang+alveoláris zárhang hangkapcsolatok után fordul elő.

b) A bilabiális és labiodentális mássalhangzók az - ок morf előtt mindig kemények. Ha a relatív tő labiális mássalhangzója lágy, vagy kemény párja váltja fel, vagy az - $u \kappa$ morf lesz használatos.

c) A tő veláris mássalhangzóit susogóhangok (шипящие) váltják fel a derivátumokban. A [ц-ч’] váltakozás szintén végbemegy, de ekkor - $-\kappa$ helyett - $и \kappa$ morffal képzendő a derivátum.

II. Az - $и \kappa$ morf: Bármilyen mássalhangzó(csoport) után, kivéve [j] és olyan susogóhangok után, amelyek a tővégi velárisokat váltják fel (ekkor - $о \kappa$ használatos). A derivátumban a tővégi [ц] helyett [ч'] áll.

III. A -чuк morf: Magánhangzó+labiális mássalhangzó vagy szonorhang hangkapcsolata, illetve [j] után.

IV. A fenti morfok nem fordulhatnak elö, ha a tővégi veláris mássalhangzó előtt is mássalhangzó áll. A евдопус ( автобус) szó hangtani jellemzői várhatóan szintén gátolják a használatukat (vö. Szpiridonova 1999: 14).

V. Szpiridonova (1999: 13-14) egy számítógépes adatbázis elemzése alapján további szabályokat állít fel a fenti morfok fonetikai korlátozására. A következő tövek esetében tehát elvileg fennáll a korlátozás:

a) egyszótagú szavak, a tő utolsó hangja [ц] vagy [н’], hangsúly a tövön

b) egyszótagú szavak, a tő utolsó hangja [ф] vagy [ц], hangsúly a végződésen

c) egyszótagú szavak, a tő utolsó hangja [ж] vagy [ч’], ingadozó hangsúly

d) többszótagú szavak, a tő utolsó hangja [б], [ж] vagy [ч’], hangsúly az első szótagon

e) többszótagú szavak, a tő utolsó hangja [д] vagy [м], hangsúly a végződésen.

Tekintettel arra, hogy orosz szóvégmutató szótárban (Lazova 1974) kevés olyan szót találunk, amely megfelel e kritériumoknak, a fenti megállapításokat nem fogadhatjuk el azonnal általános érvényünek. Annak ellenére, hogy a nonszensz szavak listáján nem tüntettem fel 
pontos hangsúlyszabályokat, a válaszok alapján mégis képet kaphatunk arról, mennyire érvényesülnek a felsorolt korlátozások.

\subsection{Nőnemü főnevek}

VI. A - $-(a)$ morf előfordulása: Magánhangzó+mássalhangzó, illetve alveoláris réshang+ alveoláris zárhang hangkapcsolatok után.

VII. Az -очк(a) morf: Bármilyen fonológiai környezetben megjelenhet, ahol állhat $-\kappa a$ is, de főként mássalhangzócsoportok és hosszú mássalhangzók után jellemző.

VIII. A прозронья, кичица szavak csonkított tövet mutató derivátumokat is lehetővé tesznek (pl. прозронка, кичка).

\subsection{Semlegesnemü fónevek}

IX. A $-\kappa(o)$ morf előfordulása: Magánhangzó+mássalhangzó hangkapcsolat után. Segítségével $-u(o)$ és $-\kappa(o)$ képzős főnevekből további szavak képezhetők. Így az абарко és зарепие szavakból elképzelhetőek például абарочко, зарепечко derivátumok.

X. Az -ышкк(о) morf: [н], [л], [p] hangok és alveoláris réshang+zöngés alveoláris zárhang hangkapcsolat után.

XI. Az -ечк(o) morf: Mássalhangzócsoportok és magánhangzó+[M’] hangkapcsolat után fordul elő. Az отомя relatív tőből várhatóan ezzel a morffal képeznek új szót.

XII. Az -ue/-[j]e végü szavakhoz feltehetőleg más morfémát (egészen pontosan az -uu(e) morfot) fognak kapcsolni. Más fonológiai környezetben is elöfordulhat, hogy a -u(o)/-eu(o)/-u(e)/-uu(e) képző jelenik meg.

\subsection{További feltételezések}

XIII. Néhány derivátum morfológiai egyezéseket mutathat egy valós főnévvel annak hangalakjához való hasonlósága miatt. Pl. a бana szóból a nana mintájára képezhető pl. бапочка, бапенька, бапуля. А вальто пальто hasonlóság olyan alakokat eredményezhet, mint а вальтишко, вальтушка. A рицо лицьо hangalak a már nem produktív $-и \kappa(o)$ morf használatát ösztönözheti ричико formában.

XIV. Személynevek ${ }^{4}$ esetén kifejezetten produktív az $-y л(\Omega) /-y \mu(\Omega) /-y c(\Omega) /-y u(a)$ és

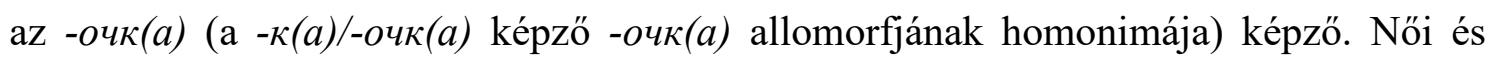
férfinevekhez egyaránt kapcsolhatók, gyakori előfordulásukra kell számítani.

\footnotetext{
${ }^{4} \mathrm{Az}$ orosz és magyar anyanyelvi beszélőknek szóló kérdőívekben kértem, hogy a válaszadók személyneveknek tekintsék a nagy kezdőbetűvel írt nonszensz bázisokat.
} 


\subsubsection{Német}

XV. A tő -el végződése esetén a -chen képző gyakrabban fog előfordulni. Ha -lein jelenik meg, akkor az $l$ előtt a schwa többnyire kiesik (Fleischer/Barz 2012: 232). Előfordulhat, hogy a schwa viszonylag gyakran megmarad, ha az -el előtt $g$ áll; szóvégmutató szótárban erre aránylag sok példát találunk, pl. Engelein, Schlingelein, Vögelein stb. (Mater 1970).

XVI. Ha a tő utolsó hangja -l(e) (nem -el), akkor a -chen képző lesz használatos. A -lein használata a szótaghatár eltolódásához és a morfémák összemosódásához vezetne (Plank 1981: 156-157).

XVII. Ha a tő végződése -ch ([x], nem [ç]), -g(e), -ng(e), akkor a -lein talán kellemesebb hangzást eredményez, ezért viszonylag nagy gyakorisággal fordulhat elő, de a szó szerkezete a -chen szuffixum használatával is transzparens marad, tehát elméletileg nem áll fenn korlátozás (Plank 1981: 158). Másfelől a Wommuch szó esetében az $u$ umlautot kaphat, aminek következtében a veláris réshang palatális lesz. Ez gátolná a -chen morfot.

XVIII. A tő [ç] végződése gátolja a -chen morfot. Ilyenkor vagy a -lein fordul elö, vagy -elchen, -erchen morfok jelennek meg. Utóbbiak viszonylag gyakoriak lehetnek akkor is, ha a tő más veláris mássalhangzóra végződik.

XIX. A tö -e és -en végződése törlődik (Fleischer/Barz 2007: 179). Olyan szavak esetén, amelyek felfoghatók egy ige infinitivusából konverzióval képzett főnevekként (pl. Ausgügen, Entliepen), az -erchen morf gyakori megjelenésére számíthatunk. Fleischer és Barz (2012: 233) a hasonló (ein)nicken > Nickerchen típusú képzést deverbálisnak tekinti, ami elfogadható, ugyanakkor nem látom akadályát, hogy alapszónak az inifinitvusból konverzióval létrehozott főnevet tartsuk. A Charochen, Tschachen szavak esetén az -en elhagyása után a -chen morf nem alkalmazható, ha a tő utolsó magánhangzója (és ezáltal az utána következő veláris réshang is) palatalizálódik.

XX. Scheidweiler (1984/85: 79) szerint a -lein képző mesei és költői konnotációt hordoz. Így azon fiktív összetett szavak esetén, amelyeknek az első (valóban értelmes) tagja mesevilág képzetét keltheti, valószínüleg föleg -lein morffal képzett derivátumokra számíthatunk.

XXI. Szintén Scheidweiler (1984/85: 79) felmérésében a legtöbb válaszadó kellemesebb hangzásúnak találta a -chen szuffixumot, mint -leint. Ebböl és a -chen gyakoribb köznyelvi előfordulásából - az arány nagyobb korpuszokban 4:1 (Fleischer/Barz 2012: 
233) - arra következtethetünk, hogy a -chen valamely allomorfja összességében többször fog megjelenni.

XXII. A tő veláris magánhangzója (majdnem) mindig umlautot fog kapni.

\subsubsection{Magyar}

XXIII. - $a$ vagy - $e$ végü főnévhez sohasem járul - $k A$ (Kiefer/Ladányi 2000b: 169).

XXIV. Az egyszótagú alapszók elvileg szintén gátolják a $-k A$ képző használatát. Vannak azonban lexikalizálódott szavak ezzel a képzővel, pl. szürke, szöke, róka, csirke (Ladányi 2007: 160-161). Nem kizárt, hogy néhány ritka esetben egyes derivátumok ellent fognak mondani a szabálynak, hiszen további fonológiai korlátozás nem áll fenn.

XXV. Kiefer és Ladányi (2000b: 168-169) szerint a $-k a$, -ke morfok nem állhatnak zárhangok után. Az MNSZ2 és a Google adatai azonban ellentmondanak ennek, nem feltétlenül csak lexikalizálódott köznevek és személynevek esetén, pl. menyétke, verébke. Ladányi (2007: 164-165) is felveti, hogy szóvégmutató szótárban kevés olyan - $d$-re vagy - $b$-re végződő főnevet találhatunk, ami nem egyszótagú, tehát a korlátozás valódi oka (ha fennáll) az egyszótagúság lehet. Mindazonáltal nem tagadható, hogy zárhangok (különösen - $g$, $-b,-p$ ) után a $-(V) c s k A$ képző jóval gyakoribb. - $k$ végű relatív tőhöz egyáltalán nem illeszkedik $-k A$.

XXVI. Szonorhangok $(l, r, m, n, n y, j)$ után a $-k A$ képző preferált, ahogy a tő - $i$ végződése után is (Ladányi 2007: 154, 164).

XXVII. Magánhangzók (kivéve $i$ ) után többnyire a -cska, -cske morfok jelennek meg. A - $(V) c s k A$ összességében produktívabb, mint a $-k A$ (Kiefer/Ladányi 2000b: 168-169).

XXVIII. Személyneveknél valószínüleg természetesebb a - $k A$ képző használata.

XXIX. Google-keresésből nyert adatok (gyalogkám, föpapka, arabkák) azt sugallják, hogy a $-k A$ képző sokszor alkalmasabb pejoratív konnotáció létrehozására, mint a $-(V) \operatorname{csk} A$, ezáltal olyan fonológiai környezetben is képes konkurens párját kiszorítani, amely egyébként annak kedvezne. Ha ez így van, a pejoratív kontextussal megadott nonszensz szavak derivátumai feltünően gyakran fognak $-k a$, $-k e$ morfot tartalmazni.

\subsubsection{A hipotézisek ellenőrzése}

Most pedig lássuk az eredményeket. Mindenekelőtt azonban fontos megjegyezni, hogy a válaszadók sokszor nem tudták úgy kezelni a nonszensz szavakat, mintha valóban anyanyelvük szókincséhez tartoztak volna. Ez különösen a német és az orosz esetében szembetűnő, mivel ott, ahol egyértelmüen a tő szabályszerü változását várnánk a szóképzés 
hatására, gyakran egyáltalán nem történt változás. Ilyenkor feltehetőleg egy oszthatatlan tőnek feltételezték a nonszensz szót, és megelégedtek a szuffixum mechanikus hozzáadásával. Így kevésbé ütközik ki a nyelv flektáló jellege. Az agglutináló magyart ez a jelenség kevésbé érinti.

\subsubsection{Orosz (I-XIV. hipotézis)}

Nonszensz szavakon is nehezen átlátható az orosz diminutívumképzés a szuffixumok bősége miatt. Meglehetősen szabadon lehet kombinálni, halmozni őket, ami olyan alkalmi szóképzéshez vezethet, mint а допозмульчик vagy дреземлеиульчик. Így aztán nem meglepö, hogy nem támaszthatunk alá olyan pontos leírásokat, mint amelyek rögzítik, milyen hangok, hangkapcsolatok lehetségesek az $-о \kappa,-u \kappa,-ч u \kappa$ morfok előtt. Annyit jelenthetünk ki, hogy közülük leggyakoribb az - $u \kappa$, mely szinte megkötések nélkül alkalmazható hímnemü alapszavakon, jóllehet [j] után valóban nem jelent meg az yстрей, экифай bázisok derivátumaiban. A II. hipotézisnek egyetlen adat nem felel meg: a мыранок > мыраночик képzés, amennyiben feltesszük, hogy a tő $-u \kappa$ szuffixummal való konkatenációja vezetett a [К-ч’] változáshoz. (Vegyük észre emellett, hogy néhol -очuк morf tünik fel; a semlegesnemü főneveket tekintve ez persze lehet mechanikus, genust figyelmen kívül hagyó konkatenálás eredménye, pl. языро $+-ч и к$, ugyanakkor a бапочик derivátum létrejötte ezzel nem magyarázható. Mintha az -oк és $-u \kappa$ morfok összefüzésével új képző keletkezett volna.) A bázis utolsó mássalhangzójának szabályszerü váltakozása esetleges (nem csak az említett morfok előtt); -ок(/-ек)/-ик/-чик például 13-szor váltotta ki a зламуz szóban a veláris plozíva [ж] hanggal való felcserélődését, 16-szor megmaradt. A IV. hipotézist a válaszok cáfolják. Ha nem is számoljuk a diminutívumképző morfok halmozását (-ичек) és olyan különös allomorfokat, mint a -чок, -шок stb., akkor is 28-szor láthatjuk a внезишк vagy лорх bázisokhoz kapcsolódni az adott morfémát (igaz, az előbbi tőből a $\kappa$ hangot 4-szer egyszerüen kihagyták). 32-szer jelenik meg az -ок(/-ек)/-ик/-чuк a евдопус tő után; e 32 szóból 28 евдопусик. Az V. pontban leírt feltevések ellenörzéséhez a бруж, ктреф, млёнь, сии, шоч, выгеребеч, някож, юскреб, илотром, оклам, отрыказд, юстлид nonszensz szavakat vehetjük figyelembe. Mindegyiknek van azonban meggyőző számú, a kérdéses szuffixummal képzett diminutívuma (összesen 260, nem számolva a formánsok halmozásával létrehozott képzőket, mint az-очек).

A nőnemü főnevekhez füzött várakozások többnyire beigazolódtak. Látható, hogy a $-\kappa(a)$ jól illeszthető már diminutívumként felfogható alapszavakhoz is, ezt mutatja például a жёлостушечка derivátum. Az -очк(a) valóban igen gyakori. Érdekes, hogy néha - ачк(a) 
formáns bukkan fel, ami lehet az a hangra végződő nonszensz szóhoz való mechanikus morfémacsatolás következménye is. Tőcsonkítás előfordul, de aránya a кичuща, прозронья derivátumai közt sem kiugróan magas.

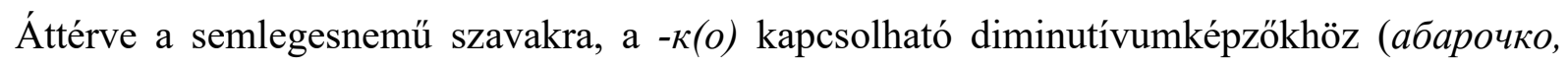
баратичко, зарепечко), ennek ellenére viszonylag ritkán találkozunk vele. Olykor magánhangzó+mássalhangzó hangkapcsolattól eltérő tővégződés után is fellép, pl. 4-szer szerepel a válaszok között a быльзздко szó. Az -ьıик(o) morfra alig találunk példát, így nincs elegendő információ a lehetséges bázisokról. Ami az -ечк(o) morfot illeti, nem tünik helytállónak a XI. pontban megfogalmazott hipotézis. Mindössze kétszer szerepel az отомечко derivátum, -ие/-[j] után viszont meglepően gyakran (13-szor) mutatkozik az adott morf, akár az -u-/-[j]- megtartásával, akár annak elhagyásával (pl. мимолянечко, приквуждиечко, улибьечко). Az -иц(е) morfot valóban csak az alapszó -ue/-[j]e végződése esetén választották több alakalommal (a 10 накеслице mellett; utóbbit talán a кресло > кресличе mintájára alkották), de ebben az esetben sem ez volt az egyetlen alkalmazható formáns, mint arra az - $е ч \kappa(o)$ előfordulása is rámutat.

Az analógiás hatások sokszor észrevehetők, ennek legvilágosabb példája a 12-szer megadott ричико (ahogy talán а вальтишко, бапуня származékok sem véletlenek). Ha a bázis személynév, nem találunk $-y л(\Omega) /-y \mu(\Omega) /-y c(\Omega) /-y u(a)$ képzős derivátumot. Az -очк(a) gyakorisága sem számottevő, ellentétben az -yuк- szuffixuméval. Ez a morféma bármilyen nyelvtani nemü bázis esetén rendkívül produktívnak tünik. Ki kell még emelni, hogy

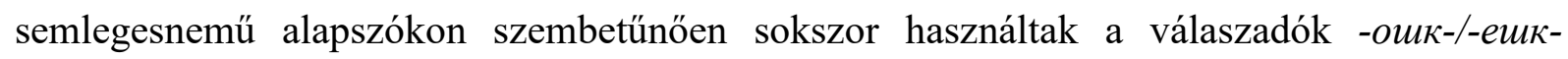
képzőt.

\subsubsection{Német (XV-XXII. hipotézis)}

A németben a bázis -el végződése esetén valóban magasan a -chen kedveltebb, mintegy 82\%ban ez szerepel. Mivel az -e- kiesése a -lein választásakor ritka, nincs valós támpont arra, hogy $g$ hang után valóban gyakoribb-e a teljes -elein. Sokan az -ellein íráskép mellett döntöttek, mely utal a szó struktúrájára. Valószínűleg a nonszensz tő bármiféle csonkításának elkerülésére való törekvést tapasztalhatjuk. Ha az alapszónak - $l$ vagy -le a végződése, kétszer annyiszor találkozhatunk -chen, mint -lein szuffixummal, ami meglepő, hiszen elméletileg -lein nem lenne alkalmazható. A XVII. hipotézis helytálló, a -lein 436-szor, konkurens párja 290-szer bukkan fel. A -chen használatát megkönnyíthette az, hogy néhány válaszadó nem törölte a szóvégi schwát. Veláris - $k$ (vagy -ke) után ugyancsak inkább -leint találunk. A Wommuch umlautjának nincs nagy jelentősége, hiszen ezt összesen hatszor 
jelölték a válaszadók (a Kindesubach szónál 12-szer). A [ç(ə)] végü töveket követően szintén a -lein kerül többségbe megközelítőleg 75\%-kal. Az -elchen néha valóban feltünik a -chen segítésére annak allomorfjaként: négyen képeztek például a Viefeiche bázisból Viefeichelchen derivátumot, Zentriegből ketten Zentriegelchent. Az -erchen morf viszont nagyon ritka, két példát láthatunk rá: Jubeldauhängerchen, Suttereierchen. Utóbbi akár régies többes számként is felfogható. A szóvégi -en és -e az esetek többségében nem törlődött, így az XIX. hipotézis nem igazolódott be. A következő feltevést sem támaszthatjuk alá: a Puppenbüble bázishoz ugyan majdnem ugyanannyiszor kapcsolódott -lein, mint -chen (a konkrét számok 29 és 32; ez a hangtani korlátozás miatt meglepö), az Entzauberhaub szó ellenben hangtanilag egyik képzőnek sem kedvez, első, valódi jelentéssel bíró tagja pedig mesevilágra utalhat, az anyanyelvi beszélők mégis 44-szer a -chen, 21-szer a -lein képzőt választották. A Riesenhepsel bázishoz pedig alig járult -lein. Összességében a várakozásnak megfelelően a -chen szerepelt többször, mintegy 63\%-ban. Ami az umlautot illeti, a XXII. hipotézis szinte megfordítható: nagyon ritkán palatalizálódott a tő magánhangzója.

\subsubsection{Magyar (XXIII-XIX. hipotézis)}

A magyarra vonatkozó kérdőívben a rogyáta és a tipe szó szolgált a XXIII. feltevés ellenőrzésére. A - $k A$ előfordulása valóban elhanyagolható. Meg kell azonban jegyezni, hogy a tipe alapszó kisebb meglepetést okozott: egyrészt 11-en választották a tipeke derivátumot (ez a szám nem jelentős, a várakozásokhoz képest mégis viszonylag nagy), másfelől 141-szer fordult elő a tipecske változat. Szabályszerüen az e nyúlását várnánk, ez a képzés (ellenben) mintha a tő csonkításával és az -ecske morf hozzáadásával járna. Még a banyódok tő az, melynek derivátumaiban többen törölték az -ok- hangcsoportot - talán többes számú alakként kezelték a nonszensz szót. Az, hogy egyszótagú bázisokhoz nem kapcsolódik - $k A$, a válaszok alapján nem tartható felvetés. Az íl, jács, vocs szavakból többnyire ezzel a szuffixummal képeztek diminutívumot (utóbbi kettő esetében talán zavarónak találták volna az egymáshoz közel kerülő két $c s$ hangot). A zárhangokra vonatkozó korlátozás egyáltalán nem igazoldódott be, nemegyszer gyakoribb utánuk a $-k A$ szuffixum. Ha az alapszó szonorhangra végződött, 58\%-ban, ha $i$-re, 70\%-ban a $-k A$ képzőt használták. Amennyiben a bázis utolsó hangja magánhangzó volt (nem számolva az $i$ mellett az $a$-t, $e$-t), a $-(V) c s k A$ ritkábban jelent meg (igaz, nem jelentős mértékben: 1716-szor az 1779-cel szemben) - ezzel ellentmondva a XXVII. feltételezésnek. Az pedig még meglepőbb, hogy a $-(V) c s k A$ összességében sem előzi meg a másik képzőt, csak mintegy 47\%-ban választották a válaszadók. Személynevekből kiindulva egészen szembetűnő a különbség: kb. 65\%-ot tett ki a - $k A$ szuffixummal történő 
képzés. Az azonban nem tünik bizonyítottnak, hogy a kontextusban megadott öt szó $-k A$ képzős derivátumai jobban illenek a mondatokba, hiszen a plozívára végződő bázisok - $(V) \operatorname{csk} A$ képzős származékai a nem személynévként megadott és mondatba nem foglalt szavakat tekintve megközelítőleg 63\%-ot tesznek ki, míg a négy releváns, kontextusba ágyazott szó esetén 58\%-ot, ami nem számottevő különbség.

Végül jegyezzük meg, hogy a válaszadók néha a két tárgyalt képzőtől eltérő formánst választottak, annak ellenére, hogy a kérdőíven feltüntetett utasítás a $-k A$ vagy $-(V) c s k A$ szuffixum használatát kérte. Erre példa a Lörébike (sőt Lörike is elöfordult tőcsonkítást mutató - $i$ képzővel) vagy a racsukácska, melyek mindenesetre figyelemre méltó szavak, az utóbbi például arról tanúskodik, hogy a magyarban elvileg lehetséges a kicsinyítő képzők halmozása.

\section{4. Összegzés: a diminutívumképzés produktivitása}

A fentiekben megkíséreltünk képet alkotni a diminutívumok morfológiájáról, illetve leginkább produktivitásáról. A termékenység fogalmát a természetes morfológia terminológiájával összhangban határoztuk meg, azonban elsősorban nem különálló képzők, hanem egy szóképzési alosztály - használjuk e terminust a Dressler és Ladányi (2000: 133) által definiált „derivatinal microclass” magyar megfelelőjeként - összes derivációs szabályának produktivitását tartottunk szem elött. Így az orosz, német és magyar diminutívumképzést hasonlíthattuk össze korpuszból nyert adatok és kérdőívek segítségével.

A produktivitás 1. és 2. kritériumát nem tudtuk teljesen elválasztani. Ehhez pontos adatokra lenne szükség mind az alapszavak, mind a diminutívumok kiejtésével kapcsolatban (hiszen megeshet, hogy egy bázisnak megmarad az idegen, az átvevő nyelv hangrendszerébe nem illő hangalakja, de a derivátum már integrálódik). Mindazonáltal egyértelmü, hogy az orosz diminutívumképzés a legkevésbé érzékeny az olyan derivációs akadályokra, mint az idegen vagy extragrammatikus szóalkotással létrehozott tövek. Itt azonban megfigyelhetjük, hogy főként gyakran előforduló, általában kisebb expresszív erővel rendelkező szuffixumokkal létrehozott derivátumokat találtunk a korpuszban, és a kérdőívekre adott válaszokban is leginkább ezek fordultak elő. A német és magyar diminutívumok képzési alosztálya szinte egyező sajátosságokat mutat: két produktív képző konkurenciája jellemző, jóllehet az egyik valamivel termékenyebb. A nonszensz szavas kérdőívek eredményei ugyanakkor azt sugallják, hogy a $-k A$ és a $-(V) c s k A$ produktivitása közti különbség kevésbé számottevő, mint a -chen és a -lein termékenysége közötti. A németben pedig még egy figyelemre méltó 
folyamatnak lehetünk tanúi: prefixáció - vagy legalábbis arra emlékeztető jelenség ${ }^{5}$ - kezd konkurálni a szuffixációs diminutívumképzéssel. Grammatikalizálódott Mini- prefixumot vehetünk észre pl. a Minicroissant, Miniklub, Miniworkshop szavakban, melyek jelen vannak a COSMAS II írott nyelvi archívumában, ellenben *Croissantchen/-lein, *Klubchen/-lein, *Workshopchen/-lein derivátumokra nincs példa. A Ponychen és Revolverchen diminutívumok mellett pedig Minipony, Minirevolver képzett szavakra bukkanhatunk.

Az egyes szuffixumok lehetséges előfordulásainak hangtani korlátozásaira vonatkozó hipotézisek jelentős része a nyert adatok alapján nem bizonyítható. Valószínüleg nem érdemes túl részletes szabályokat felállítani, inkább csak az általánosabban megfogalmazott megállapítások állják meg a helyüket, esetleg tendenciákra lehet utalni, legalábbis akkor, ha valóban fonológiai megkötésekről beszélünk. Lehetséges, hogy bizonyos hangok környezetében ritkán akadunk diminutívumképzőkre, mindazonáltal ennek oka nem feltétlenül az alapszó hangalakja. Nem zárhatjuk ki, hogy e szavak morfológiai struktúrája, esetleg szemantikai vagy stilisztikai sajátosságai nehezítik meg a kicsinyítésüket.

\section{A diminutívumképzők történeti alakulása}

Annak ellenére, hogy szinkrón vizsgálatra vállalkoztunk, néhány nyelvtörténeti tény tudomásul vétele nem fogja megzavarni munkánk fő gondolatmenetét; ellenkezőleg, talán jobban megérthetünk néhány produktivitással, illetve gyakorisággal kapcsolatos törvényszerüséget.

Ladányi (2007: 158) szerint az összetettebb, tehát több elemi képzőböl létrejött szuffixum (képzőbokor) egy adott időben jellemzően nagyobb produktivitással bír, mint a kevésbé összetett konkurens szuffixumok, melyek régebbiek, és jelentésük már jobban eltávolodott az eredetitől. Ez az érvelés teljesen meggyőzőnek tünik. Vessünk arra egy pillantást, miben nyilvánul meg a fent megfogalmazott törvényszerüség a három kiválasztott nyelvben.

Ami az oroszt illeti, az előző fejezetben nagyon sokszor egyszótagú, - $\kappa$ - elemet tartalmazó diminutívumképzők bukkantak fel. Felmerül a kérdés, miért vannak utóbbiak egyértelmü túlsúlyban a [ц] hangot felmutató morfokkal szemben. Erre Avaneszov (1968: 6-13) ad magyarázatot: az ősi - $k$ - képzőelem a bázisokhoz $\breve{l}$ vagy $\breve{u}$ hangokon keresztül kapcsolódott. A

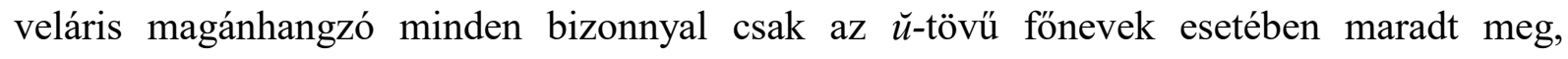
egyébként $\breve{l}$ jelent meg. A palatális magánhangzó hatására az ősszlávban a $k$-ból $c$ lett. Így alakult ki az -ъk- és az -bc- képző (pl. dvorbcb, domъkъ). Utóbbi rendkívül gyakorinak

\footnotetext{
${ }^{5}$ A Mini- morfémát Fleischer és Barz (2012: 173) a konfixumok közé sorolja, azonban maguk is megemlítik, hogy a morféma összetett szó melléknévi tagjaként is értelmezhető.
} 
számított, ám jelentése elhomályosult, és helyét elkezdte átvenni az -ъk-. Ez az oka a mai -ok és $-\kappa(a)$ elterjedt használatának. A későbbiekben nem redukált $i$ után is helyreállhatott a $k$ hang, például a korabl’ikъ szóban (Avaneszov 1968: 16). Itt már voltaképpen az -uк morf tünik fel. Ami a -чuк morfot illeti, az -bcb és -ikb toldalékok összefonódásából jött létre, pl. колоколь > колокольць > колокольчик; az utóbbi alakra meglehetősen későn, a 18. században találunk csak példát (Kiparsky 1975: 270). A mai nyelvben felettébb gyakran lép fel diminutívumok képzésnél ez a morf, tehát ismét beigazolódni látszik az összetettebb képző - nagyobb produktivitás/gyakoriság (a kettőt nem mindig tudjuk egyértelmủen elválasztani) elmélete. Sőt, a diminutívumok nonszensz szavakból történő létrehozásakor meglehetősen kedvelt -очк(a), -очек $(-b k+-b k ъ /-b c+b k ъ)$ és $-y ш \kappa-(-y m(a)+-\kappa(a))$ is megemlíthetők (Kiparsky 1975: 252, 264-265). Azonban hiba lenne leegyszerüsítenünk a tényeket. Az -yuкaligha nevezhető produktívabbnak vagy többször előforduló képzőnek, mint az -ок. Szemantikailag inkább specifikusabbnak vagy expresszívebbnek tünik: a következő fejezetben látni fogjuk, hogy szinte soha nem tünik fel, ha a derivátum jelentésének központjában mérhető tulajdonság kicsinyítése áll. Tehát nem törvényszerü az, hogy egy nyelven belül az összetettebb toldalék termékenyebb, mint az egyszerübb.

Más képet tár elénk a német. Ebben a nyelvben történeti szempontból képzőbokrokkal alkothatunk diminutívumokat. A két szuffixum párhuzamosan fejlődött, és nagyon hasonló utat jártak be. Kezdetben az ősi germán -ila(n) és -ika(n) állhatott rendelkezésre diminutívumok vagy hasonló jelentésű derivátumok létrehozására. Idővel azonban elhalványult eredeti jelentésük, majd a németben összeolvadtak az -īn szuffixummal. Utóbbi eredeti funkciója szerint melléknévképző volt, később a vele képzett melléknevek semlegesnemü alakjai főnevesültek. A képzőbokrok kialakulása olyan szavakhoz vezetett, mint az ófelnémet kindilīn 'gyermek+DIM', hūsilīn 'ház+DIM'. A középfelnémetben kitágult a potenciális bázisok csoportja, azok elvontabb denotátuma sem akadályozta a képzést: wunderlīn 'csoda+DIM', zornelīn 'harag+DIM', dankelīn 'hála+DIM'. Északabbi területeken csak a középalnémetben válik gyakorivá az - $k$ - elemet tartalmazó toldalék: manekin 'férfi+DIM', hondekin 'kutya+DIM'. Középnémet területen az ófelnémet mássalhangzóeltolódás hatására a k-ból ch lett, pl. vogelchin 'madár+DIM' (Henzen 1965: 141-147).

Úgy tűnik, a képzőbokrok körülbelül azonos korból származnak, és komponenseiket tekintve egyik sem összetettebb a másiknál. Hermann Paul (1920/1957: 49-51) figyelemmel kíséri azokat a kulturális tényezőket, melyek viszont komolyan befolyásolták elterjedésüket, illetve konkurenciájukat. Az ófelnémet és az óalnémet diminutívumok inkább csak glosszákban, fordításokban szerepelnek, talán latin minta alapján képezték őket. Mint láthattuk, ezután 
termékennyé váltak a szuffixumok, és észrevehetően elterjedtek. A déli -(i)lin és az északi -(i)kin egyaránt használatban lehetett egy határterületen. Előbb az -l- elemet tartalmazó szuffixum tünt általánosnak az irodalmi nyelvben, majd a 14. századtól mind nagyobb teret nyert konkurens párja. Luther bibliafordítása nyomán ismét a -lin nyert népszerüséget, de a 16. század végén a folyamat megfordult, és már csak a déli eredetű képzőt választékosabbnak és előkelőbbnek tituláló Sturm und Drang tudott ezen valamelyest változtatni.

A magyarban is nyomon követhetjük a két vizsgált diminutívumképző keletkezéstörténetét. Az ősmagyar korban még több elemi képző volt használatban, ezek közül a $-k$ és az -a/-e egyesülése hozta létre az újabb $-k A$ formánst. A $-(V) c s k A$ még későbbi, hiszen az előbbi képzőbokor és az elemi -cs összeolvadásáról van szó (Ladányi 2007: 158). Az ősmagyarban a - $k A$ szín- és állatnevekben jelenik meg, pl. Zeuke 'szőke', Chyrke 'csirke' (Szegfü 1991: 243244). A specializálódott jelentésű főnévi alapszavakon és beceneveken túl csak az ómagyar korban - amikor a többelemü képzők mindinkább háttérbe szorították az egyelemüeket járult újabb fönévi bázisokhoz a formáns, majd különösen a 14. századtól terjedt el. Példa erre az emberke származék. A - $(V) c s k A$ csak a kései ómagyarkorban jött létre, elöfordulása jól dokumentált: helleczken, Banyachka stb. Néha láthatjuk jelzőszerepű kettős szófajú szón is, mint az Apor-kódexben: ifiuczka timpanizalok. Összességében a századok folyamán nem sok diminutívum lexikalizálódott; a két vizsgált képzőnek ilyen származéka a már említett szín- és állatneveken túl a sóska, szálka, menyecske (Szegfü 1992: 304, 306).

A $-(V) c s k a$ tehát összetettebb képzőbokor, mint a $-k A$, ráadásul kevesebb derivátumának specializálódott a jelentése, ennek megfelelően termékenyebb is. Mindazonáltal a $-k A$ keletkezésének korából, valamint a lexikalizálódott származékszavak relatíve nagy számából a más szuffixummal képzett diminutívumokhoz képest a formáns alacsony produktivitására következtethetnénk, holott az nem nagyon marad el a - $(V) c s k A$ morfémáétól.

Úgy látszik tehát, az összetettség, gyakoriság, lexikalizáció és kulturális hatások is befolyásolják a vizsgált diminutívumképzők termékenységét valamint egy nyelven belül a konkurenciájukat. Így történeti tények ismeretében valamelyest következtethetünk a jelen nyelvállapotára.

\section{Szemantika és pragmatika}

Hogyha a diminutívumot a lehető legpontosabban szeretnénk definiálni, illetve mibenlétét megragadni a vizsgált nyelvekben, jelentős mértékben támaszkodnunk kell mind a szemantikára, mind a pragmatikára. A vizsgálathoz célszerü először a diminutívum általános jelentéséhez kapcsolódó, mindhárom nyelvben megfigyelhető közös tulajdonságokra 
rámutatni (ezek a szakirodalom alapján voltaképpen univerzálisak vagy legalábbis számos nyelvre alkalmazhatóak), majd megfigyelni a diminutívum funkcióinak konkrét realizációit, melyek nyelvenként eltéréseket tartalmazhatnak.

\subsection{A diminutívum szemantikájának alapja}

A diminutívum univerzális szemantikai alapjának feltárása az antikvitástól kezdve foglalkoztatja a kutatókat. Priscianus megjegyezte, hogy a diminutívum a bázis kicsinyítését jelöli, de használják becézés vagy udvarias megnyilatkozás kifejezésére is (Dressler/Merlini Barbaresi 1994: 85). Ez a megfigyelés az alapja a későbbi munkáknak is. A kutatók szó szerinti, tehát mértékbeli kicsinyítésről, valamiféle szubjektív, „becéző” jelentésről és egyéb, beszédhelyzettől függő használati szabályokról tesznek említést. E komponensek egymáshoz való viszonyát azonban rendkívül eltérően értelmezik, sőt az egyes jelentéselemeknek a szemantika vagy a pragmatika hatáskörébe való sorolása sem egyöntetü. Térjünk ki röviden ezekre a problémákra.

A kicsinyítést mint lehetséges jelentést ugyan nem vonja kétségbe Delhay (1995: 63-70), de vitázik az antik felfogással a bázis és a derivátum viszonyát illetően. Szerinte a derivátum nem csupán az alapszó kicsinyített vetületére vonatkozik, hanem egyenesen dekategorizáció megy végbe, tehát a diminutívum jelentését tekintve kiszakad a bázis fennhatósága alól, szembeállítható és összehasonlítható azzal. Ennek legmeggyőzőbb példája az, amikor a bázis és a diminutívum közt nem nagyobb - kisebb reláció áll fenn, hanem metaforikus, metonimikus vagy bármilyen más logikai kapcsolat. Erre használja az „abszolút diminutívum” elnevezést, de úgy véli, a valós kicsinyítést érvényre juttató „relatív diminutívum" denotátumai sem felelnek meg a bázis kategóriájának. Tehát ha utóbbi X, akkor a derivátum „nem valódi” $X$, vagyis nem egyszerüen hiponimák képzése történik. Ez a gondolatmenet védhetőnek tűnik, bár az talán kérdéses marad, mennyire jogos dekategorizációról beszélni a relatív diminutívumok esetében. Továbbá az „összehasonlítás”, mely nélkül Delhay szerint nincs is diminutívumképzés, ha nagyon jellegzetes is, inkább következménye az így még mindig pontosan meg nem határozott alapjelentésnek.

A vitáknak sokkal inkább az áll a középpontjában, hogy mit tegyünk meg a diminutívum legelemibb tartalmának. Úgy vélhetnénk, a nyelvi rendszer szemantikai szintjén csak a szó szerinti kicsinyítés ragadható meg, míg minden más csak a parole, a nyelvhasználat, az adott kommunikációs szituáció tükrében jelenhet meg. Ezzel nem egészen egyező álláspontot foglal el Dressler és Merlini Barbaresi (1994: 141-152), amikor szemantikai - ez a „kicsiség” volna -, valamint morfopragmatikai jelentésről tesznek említést. Utóbbi a beszédhelyzetre 
vonatkozik, és azt fejezi ki, hogy 'nem komoly'. Ezt az általuk maximalistának nevezett felfogást állítják szembe a ,minimalista” állásponttal, amely a diminutívum minden használatát szemantikai, a nyelvi rendszerben konvencionálisan kódolt jelentésből igyekszik levezetni. Úgy vélik, a minimalista megközelítésnek a kicsinyítést, csökkentést kell alapul vennie, de még így sem tud megnyugtató magyarázatot adni a diminutívum előfordulására olyan beszédhelyzetekben, amelyekben például kérés vagy felszólítás fogalmazódik meg. Itt a 'kicsi' jelentés hozzáadása ugyanis az illokúciós aktus gyengítéséhez vezetne, ami aligha lehetséges, inkább a kommunikációs partnerek közötti viszony bizalmassá tételéről van szó.

Ha a „kicsiséget” nem okvetlenül szó szerint, méretre vonatkoztatva értjük, korántsem kell elfogadnunk, hogy a diminutívum szemantikája erősen korlátozott, míg a legtöbb esetben a pragmatika képes csak választ adni előfordulására. A diminutívum valóban értékelő, tehát nem méretbeli kicsinyítésben megnyilvánuló funkciója nem lehet ugyanis független a szemantikától, még akkor sem, ha elfogadjuk, hogy az alá csak a jelentés konvencionális, konkrét beszédhelyzet ismerete nélkül rekonstruálható része tartozik (Kiefer 2007: 40). Az értékelés ugyan a nyelv használójától, annak szubjektív gondolkozásából ered, de nem rá vagy bármely kommunikációs partnerére, hanem egy nyelvileg jelölt objektumra (értsük most ez alatt akár absztrakt főnév jeltárgyát is) vonatkozik. Továbbá ha amellett érvelünk, hogy a diminutívum szemantikája kizárólag objektív kicsinyítést foglal magába, meglehetősen nehezen kapunk magyarázatot arra, miért illeszthető diminutívumképző olyan bázisokhoz, melyek denotátuma elvont fogalom. Igaz, ha olyan főneveket veszünk példának, mint a német Revolutiönchen vagy a magyar örömöcske, még eszünkbe juthat intenzitásbeli kicsinyítés, ami többé-kevésbé objektívnak mondható. Főleg azonban az oroszra jellemzőek olyan szavak, mint az идейка, мыслишка, смертушка, amelyeknek, úgy tünik, semmilyen mérhetö tulajdonságát nem csökkenthetjük egy skálán. Bele kellene tehát nyugodnunk, hogy e szavak jelentése a szemantika nézőpontjából, tehát a nyelvi rendszer szintjén értelmezhetetlen.

Ehelyett fordulhatunk egy strukturális jellegü megközelítéshez, mely tágabb, egységes szemantikai jelentést vagy inkább jelentéseket ajánl. Ez lehet kvantitatív vagy kvalitatív csökkentés, valamilyen érzelmileg befolyásolt korlátozás vagy akár ugyanilyen fokozás, illetve eufemisztikus vagy udvariassági finomítás (Würstle 1992: 45). E jelentések között nem szükségszerü denotatívakat és konnotatívakat megkülönböztetni, mind egyformán a diminutívum szemantikájának építőkövei. Másképp fogalmazva: a diminutívum szemantikája poliszémiára épül. A jelentések közös eleme megragadható a kicsinyítésben, ezt azonban a lehető legáltalánosabban kell értenünk. Történhet természetesen objektív, akár fizikailag mérhető kicsinyítés, de lehet egészen szubjektív is, azaz megnyilvánulhat a komolyság redukálásában 
is. Ha valamit megfosztunk komolyságának eredeti mértékétől, akkor az lehet számunkra kedves (becézés), az eredetinél kevésbé veszélyes vagy fenyegető (enyhítés), esetleg komolytalan, vagyis lenézésre méltó (pejoratív jelentés). A jelentések egy derivátumon belül együttesen is felléphetnek, hogy melyik lesz éppen az elsődleges, azt a bázison túl természetesen a kontextus határozza meg. Találó megfogalmazással élve: „So kann der Sprecher durch die Verwendung von Diminutiven seine emotionale Einstellung zum Ausdruck bringen, wobei die Komponente 'klein' je nach Kontext und Basis völlig in den Hintergrund treten kann" (Würstle 1992: 41). ${ }^{6}$ Zsemlyei (2011: 35) is megkülönböztet emotív, kvantitatív és emotív-kvantitatív diminutívumjelentést, de egyikről sem állítja, hogy az lenne az eredeti vagy elsődleges.

Nincs ellentmondás a fentiek és Jurafsky (1996: 541-569) kutatási eredményei között, aki diakrón módszerekkel a szintetikus diminutívumot univerzálisan a 'gyermek' jelentésre vezette vissza. Ebből az alapjelentésből kiindulva metaforákkal, általánosítással, következtetéssel és ún. lambda-absztrakcióval juthatunk el a további jelentésekhez, először a kicsiséghez, majd a bonyolultabb, absztraktabb szemantikai elemekhez. Jurafsky „radiális kategóriája" annyiban kedvező, hogy rendkívül pontos leírást ad, és elkerüli a diminutívum szemantikájának túlzott absztrahálását. Ha viszont csak szinkrón szempontból szemléljük a nyelvet, ez a valamelyest talán ködös elvonatkoztatás elkerülhetetlen, hiszen így nem tudjuk a 'gyermek' jelentést kiindulópontnak venni. Ezért a lehető legáltalánosabban vett kicsinyítésként értelmezzük a diminutívumjelentést; ez vélhetőleg még viszonylag könnyen átlátható koncepció. Jurafsky munkája annyiban támogatja is, hogy tulajdonképpen megkérdőjelezi a mérhető csökkentésen túli szubjektív-evaluatív jelentések pragmatika hatáskörébe való utalását, hiszen ugyanúgy levezethetők a ,gyermek” fogalmából, mint a kicsiség, legfeljebb kevésbé nyilvánvaló a kapcsolat.

Mindazonáltal még nem jártuk körül azokat az eseteket, amikor a diminutívum eddig felsorolt jelentései a szövegkörnyezetben háttérbe szorulnak, hogy a beszédhelyzet válhasson szubjektív minősítés tárgyává. Lássunk egy-egy példát az MNSZ2, a COSMAS II és az RNC adatbázisaiból (a kiemelés mindhárom esetben tőlem):

1. Lisa, Schätzchen, es ist Zeit, dein Mathe-Buch zu öffnen. ${ }^{7}$ (COSMAS II 2016. NZS12/FEB.00017 NZZ am Sonntag, 2012.02.05.)

\footnotetext{
6 „Így a beszélő a diminutívumok használatával kifejezheti érzelmi beállítottságát, miközben a 'kicsi' komponens kontextustól és bázistól függően teljesen háttérbe szorulhat."

${ }^{7}$ Lisa, kincsem + DIM, ideje kinyitni a matekkönyvedet.
} 
2. Lásd, milyen jó a napocska [...]. (egy versből, MNSZ2 2016. doc\#128)

3. Тогда, пожалуйста, дайте два билетика. ${ }^{8}$ (RNC 2003-2016. Кио, И. Э. (1999): Иллюзии без иллюзий.)

Az első példában egy szülő igyekszik lányát tanulásra rávenni. Bár a Schätzchen szó gyermeket jelöl, itt nyilvánvalóan nem a gyermek fiatalságának vagy kicsiségének hangsúlyozása áll a középpontban, hanem a beszélö és a hallgató közötti bizalmas viszony. A második példában megszemélyesített nap szerepel, a diminutívum részben ennek megerösítésére is szolgálhat. Ha abból indulunk ki, hogy a beszélő a napot szubjektíven kedvesnek, élőnek tünteti fel, elegendő a szemantikai jelentésre támaszkodnunk. Itt azonban nem a szokásos értékelés történik, a beszélő aligha a nap, sokkal inkább a megszólított gyermek iránti érzelmeit fejezi ki. Ez az oka annak, hogy gyerekekkel való kommunikációban olyan sokszor találkozunk diminutívummal. A bizalmas kapcsolat úgy jut kifejezésre, hogy az egyébként a hallgatóra vonatkoztatható kicsinyítés eltolódik a külvilág objektumaira. Ez a jelenség nevezhető „xenodenotatív átcímzésnek” (Zemszkaja/Kitajgorodszkaja/Sirjajev 1981: 113). Végül a harmadik példa egyszerü jegyvásárlást mutat be. Magától értetődik, hogy itt a felsorolt szemantikai jelentések nem érzékelhetőek, a beszélő csupán a kérés szituációjában általánosan elfogadott, nem túl hivatalos hangnemet igyekszik megütni, а билетик szó választása talán leginkább stilisztikai megfontolásra vezethető vissza. Eközben az illokúciós aktus ugyanolyan erejü marad, mintha a diminutívumot a bázis helyettesítené.

Le kell azonban szögeznünk, hogy a fenti megnyilatkozások elvesztenék expresszivitásukat, ha a diminutívum használatát áttételesen nem motiválnák a szemantikai jelentések. A szituáció jellegére csakis azáltal történhet utalás, hogy valamit „kicsinyítve” ábrázolunk, amit önmagában nem feltétlenül kellene így szemléltetni. Néha ez az ,álkicsinyítés” a nyelvi megnyilatkozás valamely összetevőjének fokozását is maga után vonhatja, vegyük az alábbi példákat:
a) Adj már egy szeletet!
b) Adj már egy szeletkét!

Elképzelhető, hogy b) nagyobb illokúciós erőt ér el, mint a), miközben szó sincs a szelet méretéről, és talán szubjektív értékeléséről sem.

\footnotetext{
${ }^{8}$ Akkor, kérem, adjon két jegyet $+D I M$.
} 
A fenti funkciókat tekinthetjük a szemantikai jelentések sajátos konnotációinak vagy kifejezetten pragmatikai jelentéseknek. Ha az utóbbi értelmezést választjuk, azt mondhatjuk, hogy a szövegkörnyezet és a beszédhelyzet vagy szabad utat enged a szemantikai jelentéseknek, vagy pedig újabb, a szituáció ismeretében feltárható jelentésekké változtatja őket.

A továbbiakban azt követhetjük nyomon, hogyan aktualizálódhatnak az alapvető szemantikai jelentések tisztán kicsinyítő és evaluatív (ha úgy tetszik, expresszív), illetve beszédhelyzetre vonatkoztatható funkcióban. Lényegében ezt a felosztást alkalmazza Würstle (1992: 140-142) is. Ám mielőtt rátérnénk ezekre a konkrétumokra, vessünk még egy pillantást arra, hogyan szokás osztályozni, általánosabb jelentéstani kategóriákba sorolni a diminutívumot az egyes nyelvek leírásában.

A diminutívum és az augmentatívum szubjektív-evaluatív jelentéseket hordoz (az orosz terminológiában: субъективно-оценочные значения). Egyetérthetünk Dressler és Merlini Barbaresi (1994: 153) következő meghatározásával:

Diminutive formation is evaluative [...], that is, diminutives express an evaluation or judgement ,as to value" (not ,as to fact"), according to the evaluator's intentions, perspective and standards of evaluation. An evaluation can also be characterized as an appreciation, that is, as a mental operation which assesses the value of an object or event. ${ }^{9}$

Kétségkívül igaz ez a becéző (illetve az ennek sajátos változataként is felfogható enyhítő) és a pejoratív jelentésre, valamint ezeknek a mértékbeli kicsinyítéssel való kombinációira. Ha azonban kizárólag mértékbeli kicsinyítéssel van dolgunk, nem tünik ennyire egyszerünek a válasz. Rendkívül nehéz megállapítani, mikor aktualizálódik kizárólag ez a jelentés, végtére is úgy tünik, önmagában bármelyik nem lexikalizálódott, diminutívumképző szuffixummal ellátott szó rendelkezik azzal a potenciállal, hogy egyértelműen szubjektív-evaluatív tartalmat (azaz nem vagy nem csak mértékbeli csökkentést) fejezzen ki. Ha mégis olyan kontextust keresünk, amely kizárólag szó szerinti kicsinyítést aktualizál, gyakran előforduló, szokásossá vált diminutívumot kell kiválasztanunk. Ennek oka a lexikalizáció folyamatát kísérő jelentésváltozás. Würstle (1992: 139) szerint minél szokatlanabbnak hat a diminutívum, annál jobban érzékelhető az érzelemkifejező funkciója. Ennek nyilván a fordítottja is igaz: a struktúrájukat tekintve még transzparens, de már lexikalizálódottnak mondható

\footnotetext{
${ }^{9}$ „A diminutívumképzés evaluatív [...], vagyis a diminutívumok értékelést vagy értékre (nem tényre) vonatkozó ítéletet fejeznek ki az értékelő szándékainak, nézőpontjának és értékelési normáinak megfelelően. Az értékelés megbecsülésként is jellemezhető, azaz olyan gondolati műveletként, mely egy objektum vagy esemény értékét állapítja meg."
} 
diminutívumok tehát várhatólag a kicsiség képzetét fogják kelteni. Amennyiben a bázis már nincs jelen a nyelvben, akár ez is elhomályosulhat.

Az RNC alapkorpusza а гвоздик lexémára 1702 találatot jelez, ami nem túl sok, de egy diminutívumhoz képest kevésnek sem nevezhető. Vegyük a következő példát (a kiemelések tőlem):

4. Потом я вынес клетку на балкон, повесил её на гвоздик и открыл двериу. (RNC 2003-2016. Коваль, Юрий (1972): Капитан Клюквин.) $)^{10}$

Feltételezhetjük, hogy az elbeszélő célja itt nem a mellékesen megemlített szöghöz való hozzáállásának kifejezése. Egyszerüen kicsi szögről van szó, olyanról, amely tipikusan alkalmas arra, hogy ketrecet akasszanak rá. A двери̧а szó jellegzetes denotátuma még egyszerübben kijelölhető: valamilyen használati tárgy (kis) ajtaja. Mivel házajtót nem szokás a дверияа szóval megnevezni, kijelenthetjük, hogy ez a diminutívum lexikalizálódni kezd. A fenti idézetben tehát nem igazán érhetjük tetten a beszélő szubjektív-evaluatív attitüdjét. Mindazonáltal nem teszünk különösebb engedményt, ha általánosan elfogadjuk, hogy a diminutívum szubjektív-evaluatív jelentésekkel bír.

Végül, ha még általánosabb kategóriában gondolkozunk, eljutunk a modifikációig. Ezt többféleképpen próbálták meghatározni. Hentschel és Weydt (2013: 181) szerint modifikáció esetén a szófaj változatlan marad, miközben az alapmorfémához affixumok kacsolódnak, esetleg a szótő valamely mély magánhangzójának változása mellett (umlaut). Ezzel a megközelítéssel az lehet a probléma, hogy a diminutívumképzés, mint Fleischer és Barz (2012: 234-235) is rámutat, a németben ritkán szófajváltással járhat, pl. früh > Frühchen, dumm > Dummchen. Az oroszban is elképzelhetők olyan melléknévi alapú képzések, mint a дурной > дурнышкка, ahol a képzett fónév nem egyszerüen az adott tulajdonság hordozóját jelöli, hanem jelentése szubjektív elemet is tartalmaz (Lopatyin 1982: 175). Az oroszban az ilyen derivátumokat azonban el szokás választani a diminutívumoktól. Tény, hogy a modifikációra nem jellemző a szófajváltás, de ha a diminutívumot is ebbe a kategóriába soroljuk, szerencsésebb egy jelentésközpontú definíciót alapul vennünk: „Сущность словообразовательной модификации заключается в добавлении к основному значению мотивирующего слова некоторого дополнительного элемента смысла" (Lopatyin 1982: 183). ${ }^{11}$

\footnotetext{
${ }^{10}$ Aztán kivittem a kalitkát az erkélyre, felakasztottam egy szögre $+D I M$, és kinyitottam az ajtaját + DIM.

${ }^{11}$ „A szóképzési modifikáció lényege bizonyos kiegészítő értelmi elem hozzáadása a bázis alapjelentéséhez."
} 
Úgy látszik, az sem egységes - még egy nyelv leírásán belül sem -, pontosan mi sorolható a modifikációhoz. Würstle (1992: 27) csak a diminutívumot és az augmentatívumot említi, Fleischer és Barz (2012: 120) fönévképzés esetén ezek mellett a nőnemü alak képzése (Movierung), valamint a ,értékelő” (taxierend), „negáló” (negierend) és „kollektiváló” (kollektiv) jelentésü szavak derivációját hozza fel példaként. A „Rövid orosz nyelvtan” a következő jelentéseket sorolja ide: nőnemű alak képzése, élőlény nem felnőtt mivolta, valamihez való hasonlóság, kollektívum, individuum, szubjektív-evaluatív jelentés, stilisztikai modifikáció (Svedova/Lopatyin 1989: 65-71). A modifikáció problémájára nem térhetünk ki, de azt fontos lehet megjegyezni, hogy az oroszban a felsorolt modifikációs jelentéseket gyakran alakilag ugyanazok a szuffixumok jelölik. Például a $-\kappa(a)$ hangsor nem csak diminutívumképző morf lehet, hanem nőnemet, hasonlóságot és stilisztikai modifikációt is kifejezhet. Diakrón szempontból ugyanarról a képzőről van szó, de szinkrón szinten a jelentések között semmilyen hasonlóság nem mutatható ki (vagy ez alig érzékelhető), ezért beszélhetünk homonímiáról. A legnagyobb nehézséget talán a diminutívum és a tisztán stilisztikai modifikáció megkülönböztetése okozza, a határok itt elmosódhatnak. Nem is okvetlenül szükséges efféle feladatra vállalkozni, a köznyelv kutatásában például teljesen kielégítő az expresszív szóképzést körülhatárolni (Zemszkaja et al. 1981: 112).

Ugyan a „Strukturális magyar nyelvtan 3.” (Kiefer/Ladányi 2000b) nem rendeli szubjektívevaluatív jelentés és modifikáció alá a diminutívumot, egyszerüen a morfoszintaktikailag semleges képzések alatt tárgyalja, a magyar nyelvben is megállja a helyét a két említett általánosabb kategória (amennyiben a „morfoszintaktikailag semleges képzések” meghatározást nem tekintjük a modifikáció abszolút szinonimájának).

\subsection{A jelentés megnyilvánulásai}

Vizsgáljuk először meg, milyen külső, mérhető jegyeiben térhet el a diminutívum denotátuma a bázisétól. Ez a különbség többnyire valamilyen (magára az objektumra vagy a beszédhelyzetre vonatkoztatott) szubjektív tartalom mellett van jelen, mint fent már láthattuk, csak lexikalizáció irányába mutató szavak esetén lép fel a mértékbeli csökkentés más jelentés nélkül. A következő pontokban vegyük sorra a Szpiridonova (1999: 15-20) által az orosz nyelvre megállapított kicsinyítési típusokat (itt $\mathrm{A}-\mathrm{H}$ betükkel jelölve, némileg átrendezve), majd győződjünk meg róla, megvannak-e ugyanezek a kategóriák a német és a magyar nyelvben, esetleg felmutatnak-e további, oroszra nem jellemző realizációs lehetőségeket. A felsorolt orosz mintaszavak többségét Szpiridonova is említi. 
A) A méretbeli kicsinyítés legkézenfekvőbb esete az, amikor az objektum valamennyi vonalszerü paramétere (szélessége, hosszúsága, magassága) redukálódik. A bázis jelentése alapján további alkategóriákat különíthetünk el (Szpiridonova 1999: 17). Hozzunk ezekre mindhárom nyelvből példát (lehetőség szerint ugyanazon vagy hasonló objektumok megnevezését a különböző nyelveken):

- Bútordarabok: креслице, полочка; Stühlchen, ${ }^{-}$Regälchen; ${ }^{-}$székecske, ${ }^{-}$polcocska

- Edények: блюдечко, кастрюлка; Schüsselchen, Töpfchen; tálka, -fazekacska

- Földterület: лесок, лужок; Wäldchen, Wieschen; erdöcske, rétecske

- Települések: городок, деревенька; Städtchen/Städtlein, Dörfchen/Dörflein; városka, falucska

- Rögzített funkciójú kisebb tárgyak: винтик, ключик; Schräubchen, Schlüsselchen; -kulcsocska, ${ }^{-}$csavarka

- Szerszámok, nagyobb használati tárgyak: топорик, - грабельки; ${ }^{-}$Härkchen, ${ }^{-}$Beilchen; -gereblyécske, ${ }^{-}$baltácska

- Tárolóeszközök: сундучок, чемоданчик; Kistchen, Köfferchen; ládikó, -böröndöcske

- Helyiségek: кухонька, подвальчик; Küchlein, ${ }^{-}$Kellerchen; ${ }^{-}$konyhácska, ${ }^{-}$pincécske

- Építmények: балькончик, фонтанчик; '-Balkönchen, - Springbrünnchen; - erkélyecske, szökökutacska

- Épületek: башенка, церковка; Türmchen; Kirchlein; tornyocska, templomocska

- Rések, kivágások: щеёлка, окошко; Fensterchen, ${ }^{-}$Risschen; ablakocska, ${ }^{-}$lyukacska

- Mélyedések: пещчерка, ямка; Grübchen, ${ }^{-}$Höhlchen; ' gödröcske, ${ }^{-}$barlangocska

- Vizek: озерия, ручеёк; Seelein, Flüsschen; tavacska, folyócska

- Kisméretü állatok: жучок, воробушек; Käferchen/Käferlein, - Spätzchen; bogárka, verébke

A kiindulásnak vett orosz példák mindegyike megtalálható Tyihonov (1985) kétkötetes szóképzési szótárában. Minden felsorolt orosz, német és magyar szó megtalálható az RNC, a COSMAS II, illetve az MNSZ2 korpuszaiban. A - jellel megjelölt szavakra kiadott találatok száma messze nem éri el a százas nagyságrendet. A számottevő gyakoriság (illetve az orosz példák esetén a szóképzési szótárban való megjelenés) azért lehet fontos, mert arra utal, hogy a diminutívum viszonylag megszokottnak számít, semmiképpen sem tekinthető neologizmusnak. Úgy tünik, a ritkább alakok nagyobb expresszív erővel rendelkeznek, így a fizikai kicsinyítés mozzanata esetükben erősen háttérbe szorulhat. Ha a diminutívum térbeli 
csökkenésben megnyilvánuló jelentését keressük, érdemesebb tehát gyakoribb, de még nem lexikalizálódott szavakat keresnünk.

Felmerülhet továbbá a kérdés, hogy miért nem vettünk be a példák közé olyan kézenfekvőnek látszó szavakat, mint a столик/Tischchen/asztalka, melyek gyakran fordulnak elő a vizsgált nyelvekben. Amellett, hogy nyilvánvalóan itt csak az egyes kategóriák rövid, messze nem kimerítő bemutatására vállalkozhatunk, a fenti példát azért sem lett volna célszerű feltüntetni, mert a derivátum denotátuma a bázisétól sokszor leginkább funkciójában tér el. Ellentétben egy kis székkel, mely méretétől függetlenül ülőalkalmatosság marad, a kicsi asztal (pl. dohányzóasztal) egészen más szerepet tölt be, mint egy étkező- vagy íróasztal.

A fent megadott alkategóriák némelyike eléggé korlátozott számú elemet tartalmaz, emellett talán az orosz nyelvi világképbe jobban illenek, mint a németbe és magyarba. Mindazonáltal ha együttesen szemléljük őket mint többé-kevésbé állandó alakú és méretü, minden dimenziójukban egyszerre kicsinyíthető vagy nagyítható jelenségeket, bizonyára van némi alapunk az összehasonlításra. Mindhárom nyelvben kifejezhetnek a diminutívumok elsősorban - esetleg szubjektív-evaluatív tartalom kifejezése mellett - általános mértékbeli kicsinyítést. A legszélesebb körben ezt a jelentést minden bizonnyal az orosz képes érvényre juttatni. Az „erkély” és „szökőkút” méretbeli redukálása kevésbé jellemző a németre és a magyarra, mint az oroszra. Máskor a német és a magyar csak általánosabb jelentésű szavakból képez gyakran előforduló diminutívumot, míg az oroszban ugyanez a hiponimákra vagy legalábbis szükebb fogalomkörben értelmezhető főnevekre is igaz. A helyiségek közül a magyar inkább csak a specifikusabb példák közt nem említett, általános jelentésü szobát jelenítheti meg diminutívumhasználattal kicsinek (az MNSZ2 519 találatot ad ki a szobácska szóra), a német emellett a „konyhát” is (a COSMAS II írott nyelvi archívumában a Zimmerchen szóra 897 találatot, a Küchlein-ra 468-at láthatunk). Az orosz ezt az eljárást más helyiségekre is alkalmazza (pl. még az idegen eredetű bázisból képzett кабинетик derivátumra is 348 találatot ad ki az RNC alapkorpusza). A második helyen a jelek szerint a német áll. A magyarban az eleve apró tárgyak további méretbeli csökkentése valóban szokatlan lehet, míg a németben Schräubchen (781 találat) és a Schlüsselchen (98 találat) elterjedtebb.

Eddig tehát olyan eseteket láttunk, ahol a diminutívumképzés a „kicsi” jelző alkalmazásához hasonló szerepet tölt be, ugyanis a nagyság megjelölése olyan objektumokon müködik a legjobban, melyek a térben - különösen a szélességet és hosszúságot tekintve - több vonalszerüen felfogható oldallal rendelkeznek (Rahilina 1994: 66-70). Ebből a szempontból figyelmet érdemelnek a testrészek és a ruhák is, hamarosan ezekre is kitérünk. 
B) $\mathrm{Az}$ oroszban gyakran előfordul, hogy a diminutívum csupán egy térbeli paraméter kicsinyítésére utal. Ez hosszúkás objektumok esetén többnyire a szélesség, néha a hosszúság csökkentését jelenti, pl. веточка, ленточка, полоска, поясок. A németben is viszonylag könnyü példákat találni: Ästchen, Bändchen, Streifchen, Strichlein. A magyarban az ágacska, nyilacska, rudacska, vonalka szavakat említhetjük.

C) Ugyancsak jellemző az oroszra, hogy a diminutívum denotátumai a báziséhoz képest vékonyabbak, anyaguk kevésbé sürü: кофточка, свитерок, халатик, тапочки, занавесочка, мешочек, стаканчик, шкурка, ледок ('vékony jégréteg') stb. Látható, hogy rendkívül különböző jelentésű szavak tartoznak ide, sőt még ebbe a csoportba sorolhatjuk a кустик, лесок diminutívumokat is, amennyiben 'ritka bokor', 'ritka erdő' értelemben használatosak. E jelentés nyomatékosítására szolgálhat a редкий jelző: редкий кустик, редкий лесок. Természetesen ez nem zárja ki azt, hogy a лесок főnév csak az erdő területének kicsiségét hangsúlyozza, ezt bizonyítja а густой лесок jelzős szószerkezet, melyre az RNC két példát tartalmaz. Ez a kevésbé prototipikusnak nevezhető diminutívum nem gyakori a németben és a magyarban. Vékony fedőréteget például nem szokás ezekben a nyelvekben kicsinyített főnévvel megnevezni. Ha mondhatjuk is, hogy „vékony jegecske” (az MNSZ2ben is találunk rá példát), ez a szószerkezet semmiképpen nem tekinthető megszokottnak. Leginkább olyankor fordul elő hasonló jelentésű diminutívum, ha funkcióváltás is történik. A мешочек/Säckchen/zsákocska például kicsi, vékony zsákot jelöl, amelybe rendszerint kisebb, finomabb tárgyakat helyeznek, mint bázis denotátumába. A Gläschen és a pohárka alapvetően nem papír- vagy műanyagpoharat jelent, mint az oroszban a стаканчик, hanem a pohárba töltendő folyadék mennyiségére utal, ezért utána rendszerint anyagnév áll: ein Gläschen Wein, egy pohárka bor (ez persze az oroszban is lehetséges: стаканчик вина/винца).

D) Ami a ruhadarabokat illeti, a derivátumok (Hemdchen, Jäckchen, Mäntelchen, ingecske, kabátka) azért nem a legmeggyőzőbb példái a vastagság/anyagsűrüség kicsinyítésének, mert jellegzetesen (ha nem is kizárólag) női vagy gyermekruhák jelölésére alkalmasak. Ez az oroszra is vonatkozik, amelyben ez a jelentéselem néha az anyag vastagságának változatlansága mellett jut kifejezésre: шляпка, сапожки (vö. Stiefelchen, cipőcske). A diminutívum használatának alapja nyilvánvalóan az lehet, hogy a női és gyermekruhák általában kisebbek, mint a férfiöltözék darabjai. Női ruhadarabok megnevezésekor - pl. юбочка, Röckchen, szoknyácska - természetesen rövid vagy a prototipikushoz képest kicsi tárgyról van szó, de az is gyakori, hogy egy kedves, szép hölgy leírásához a beszélő többnyire idősebb férfi - diminutívumokkal kívánja fokozni nyelvi megnyilatkozásának 
expresszivitását (Würstle 1992: 184). Hasonló jelenség ez a gyermekekkel való kommunikációban tapasztalt xenodenotatív átcímzéshez.

Érdemes itt megjegyezni, hogy a testrészek elnevezése a ruhadarabokéhoz hasonlóan viselkedik. А лобик, носик, ручка, ножка, ушик; Händchen, Äug(e)lein; kezecske, lábacska gyermek- vagy női testrészekre vonatkoznak.

E) A diminutívum kifejezheti az oroszban az egész részét vagy levágott darabját is: бумажка, ватка, шоколадка, мелок, чешуйка, верёвочка, ниточка. A magyarban és a németben ez nem figyelhető meg.

F) Bizonyos légköri, időjárási jelenségek intenzitása is redukálható az oroszban diminutívumokkal. Ilyen például a ветерок, дождик, сквознячок. Ennek megfeleltethető a német Lüftchen, Windchen. A дымок és парок is hasonló, melyek a légnemü jelenség alacsony sűrüségét (pl. vékony füstoszlop) mutatják. A magyarban ismét más eszközökkel fejezhető ki ugyanez a tartalom, pl. szellö, szemerkélö esö.

G) Állatneveket tekintve a diminutívum két különleges jelentéssel bírhat: az adott állat kicsinye: бегемотик, барашек, бычок, козлик; vagy játék: слоник, лисичка. Alkalomadtán növényt jelentő bázisokból is létrehozható fiatal élőlényt jelölő derivátum: дубок, яблонька, кустик, травка. A másik két nyelvben mindez jóval korlátozottabban jelenik meg. A németben a Kätzchen jelent tipikusan állatkölyköt. Nem feledkezhetünk meg a COSMAS II írott nyelvi archívumában viszonylag gyakori (néhány ezer találat) Hündchen vagy Pferdchen szavakról sem, de ezekben az esetekben rendelkezésre áll az általánosabb Welpe és Fohlen. Jellegzetesen játékszer értendő a Bärchen alatt. A növényeket tekintve az olyan derivátumok, mint a gyakori Bäumchen és Tännchen kicsi, de nem okvetlenül fiatal fát ugyanúgy megnevezhetnek, mint csemetét. Áttérve a magyar nyelvre, az állatnév bázisú diminutívumok elsősorban szubjektív-evaluatív jelentést juttatnak érvényre, a kicsinyeket rendszerint önálló tővel (bárány, csikó, malac) vagy kis előtaggal (kismacska, kiskutya) lehet megnevezni. Játékok esetében sem kötelező a diminutívum használata, bár a rendhagyó becéző alakként felfogható maci/mackó nem igazán helyettesíthető más fönévvel (pl. medve vagy ?játékmedve). Úgy tünik, a növénynevek közül csak a fácska fordul elő rendszeresen (az MNSZ2-ben 448 találat), amely kicsi és fiatal fát egyaránt jelenthet. Érthetö, hogy a diminutívumképzős orosz növénynevek jobban kifejezik a 'fiatal' jelentésárnyalatot, hiszen gyakran specifikus növényfajtákra vonatkoznak, amelyek mérete fajtól függően többékevésbé meghatározott. Ha csak általában a fa főnévből képzünk diminutívumot, akkor az kiválóan vonatkoztatható például törpefenyőre, amely nyilvánvalóan jóval kevésbé méretes, mint egy mindennapi gondolkodásban általánosnak vett fa. 
H) Végül meg kell említenünk, hogy az oroszban a megszokott bázis-derivátum reláció néha látszólag felborul. A diminutívum alá fognak tartozni a prototipikus denotátumok, míg a bázis augmentatívumként fogható fel. Példák erre a ёж - ёжик, дыра - дырка, игла - иголка szópárok. A másik két vizsgált nyelvben ilyesminek nincs nyoma.

Szpiridonova (1999: 20) megemlíti a „bázis denotátumának való rendeltetést” is a lehetséges diminutívumjelentések között, ilyen lenne többek közt a ручка 'kilincs' értelemben ('az emberi kéznek rendeltetett eszköz'). Itt azonban talán már szerencsésebb homonim derivációs morfémákról beszélni, mint ahogy a студентка származékot sem szükséges a студент diminutívumaként felfognunk. Kiefer (2007: 126) munkája alapján definíciós kritérium segítségével különválasztható a poliszémia és a homonímia. Ha a szó jelentésének pontos leírásához több definícióra van szükségünk, amelyeknek van közös eleme, akkor poliszémia áll fenn, ha a közös elem hiányzik, akkor homonímia. Ha úgy határozzuk meg a diminutívum lehetséges szuffixumainak jelentését mint a lehető legáltalánosabb értelemben vett kicsinyítést, amely szubjektív-evaluatív expresszivitást adhat hozzá a nyelvi megnyilatkozáshoz, akkor látszólag nagyon nehéz bármi kapcsolatot találni az alapszó denotátumának való rendeltetést kifejező képzőkkel. Így érdemes lenne elkülöníteni funkcióváltást és imitációt. Szpiridonova e két csoport között nem von határt, de úgy tűnik, jelentős eltérés van a bázis méretbeli kicsinyítéséből adódó funkcióváltás - erre volnának példák a шкаф (nagyobb szekrény, pl. ruhásszekrény) és a шкафчик (kisszekrény, pl. fiókos szekrény) viszonyához hasonló relációt kifejező párok - és az alapszó denotátumához való puszta hasonlóság között. A ножка 'bútor lába' értelemben valójában nem kicsi lábra utal, amelynek méreteiből következően más szerepe van, mint az átlagos lábnak. Egyszerüen funkcionális imitációval állunk szemben, ezt pedig nyugodtan elválaszthatjuk a diminutívumoktól, más modifikációs csoportba sorolva a jelenséget.

A szakirodalomban meg szokták állapítani, hogy bizonyos főnevekből jelentésükből adódóan nem képezhető diminutívum. Szpiridonova (1999: 15-16) egész sor korlátozást felsorol, Rahilina (1994: 79) szerint pedig а поле, пашня, пропасть szavakhoz hasonló, prototipikusan nagy objektumot jelölő szavakból sokszor nem hozható létre diminutívum, de rögtön hozzá is füzi, hogy ne vegyük figyelembe a „hipokorisztikus formákat”. E formák elkülönítését nem kell elfogadnunk, hiszen láthattuk a diminutívum általános szemantikájának tárgyalásakor, hogy a szubjektív-evaluatív jelentést szükségtelen elválasztani a méretre vagy intenzitásra kicsinyítéstől. A másik gyakran hangoztatott megszorítás az, hogy diminutívumképző kizárólag vagy majdnem kizárólag „konkrét főnevekhez” járulhat, lásd pl. Hentschel és Weydt (2013: 181) vagy É. Kiss et al. (2003: 237) munkáját. Mindezek a kijelentések persze 
nem alaptalanok, hiszen elvont denotátumú főnevekből valóban ritkább a diminutívumképzés, ám nem tagadhatjuk például a мыслишка, Ideechen, eszmécske derivátumok létezését. Prototipikusan nagynak tekintett objektumok kicsinyítése sem túlságosan gyakori, és a Szpiridonova által megfogalmazott további korlátozások is többé-kevésbé tarthatóak, a лифm, рояль, трактор, циикуль szavakhoz hasonló, erősen „funkcionális” tárgyak kicsinyített változatai is nagyon ritkák, esetleg elő sem fordulnak az RNC-ben (pl. egyáltalán nincs *ичркульчик).

Ha viszont inkább olyan szabályokat keresünk, amelyek jó eséllyel mindhárom vizsgált nyelvben potenciális szavakként is kizárják a diminutívumokat, aligha tudunk teljes bizonyossággal bármit megállapítani. Feltehetjük, hogy a valóban hatalmas méreteket öltő objektumokról általában nem szokás kedveskedő vagy becéző hangon sem beszélni, pejoratív jelentés azonban itt is aktualizálódhat. A небоскрёб/Wolkenkratzer/felhőkarcoló bázisok esetén ez lehetséges. Az RNC-ben az alábbi példát találjuk:

5. Огни, позолота, никель и зеркала, три небоскребчика для престижа ${ }^{12}$ (RNC $2003-^{\text {O }}$ 2016. Песков, Василий/Стрельников, Борис (1977): Земля за океаном.)

A COSMAS II írott nyelvi archívumában kétszer fordul elő a Wolkenkratzerchen. Itt nem pejoratív hangvétellel találkozunk:

6. Ein Wolkenkratzerchen steht schon, die anderen sind noch Computer-Vision ${ }^{13}$ (COSMAS II 2016. RHZ06/JAN.05578 Rhein-Zeitung, 2006.01.09.)

7. Das Capitol in Bismarck ragt neunzehn Stockwerke hoch als einsames Wolkenkratzerchen in den leuchtenden Himmel über Dakota und grüßt die auf der Interstate 94 anreisenden Besucher von weitem ${ }^{14}$ (COSMAS II 2016. Z98/807.04314 Die Zeit, 1998.07.30.)

Ha az MNSZ2 nem is ad ki találatot a felhőkarcolócska szóra, egyszerű Google-kereséssel meggyőződhetünk arról, hogy elvétve ez a derivátum is aktualizálódik. Diminutívumképzést egyértelműen kizátó alapszavakat talán az idegen eredetü szakkifejezések körében kell keresnünk, bár a Yandex még а молекулка diminutívumra is 9 ezer találatot (2016.11.27.)

\footnotetext{
${ }^{12}$ Lámpák, aranyozás, nikkel és tükrök, három felhökarcoló + DIM a presztízs kedvéért.

${ }^{13}$ Egy felhőkarcoló + DIM már áll, a többi még számítógépes terv.

${ }^{14}$ A bismarcki székház tizenkilenc emeletével egyetlen fehőkarcolóként $+D I M$ tör a Dakota fölött világító égbe, messziről köszöntvea 94-es országos autópályára érkező látogatókat.
} 
jelez. Úgy látszik, legfeljebb arról szólhatnánk, hogy az egyes nyelvekben milyen típusú bázisokból nem jellemző a diminutívumképzés, de egyértelmű szemantikai korlátokat nem állíthatunk fel.

A továbbiakban térjünk ki röviden a szubjektív-evaluatív jelentések realizációira. Itt meg kell elégednünk néhány, internetes korpuszokból kiválasztott példával, hiszen részletes leírás az alapszó és a származék viszonya szerint aligha lehetséges.

A legalapvetőbb esetben a beszélő becézi a számára (vagy az általa éppen leírt személy számára) kedves objektumot:

8. Список опций (а ими моя машинка снабжена по максимуму) и вовсе непривычен для скромного А-класса (...) $)^{15}$ (RNC 2003-2016. Нечетов, Юрий (2004): Восьмой лауреат. In: За рулем (2), 2004.02.15.)

9. Stolz deutet der 58jährige auf das blitzblanke Autochen mit den externen Scheinwerfern und der klappbaren Sonnenblende. ${ }^{16}$ (COSMAS II 2016. R98/AUG.69404 Frankfurter Rundschau, 1998.08.31.)

10. Mivel a Renault pajkos autócskája már a nemzetközi menetpróba alkalmával elnyerte tetszésemet. (sajtócikkből, MNSZ2 2016. doc\#1368)

Ezekben a példákban a hangsúly nem az autó méretén, hanem valamilyen személynek a hozzáállásán van.

Ha alapvetően veszélyt jelentő bázisból képzünk diminutívumot, akkor a fenyegetés enyhítése lehet a végeredmény:

11. Вчера был у Сафариков небольшой пожарчик, но сошло. ${ }^{17}$ (RNC 2003-2016. Болдырев Александр (1941-1948): Осадная запись (блокадный дневник).)

12. Thomas Bucheli, seines Zeichens Wetterprophet der Schweizerischen Meteorologischen Anstalt, versprach für den 28. August einen sonnigen Tag. Schlimmstenfalls ein paar Regentröpfchen oder Gewitterchen so gegen Abend. ${ }^{18}$ (COSMAS II 2016. A99/SEP.60925 St. Galler Tagblatt, 1999.09.03.)

\footnotetext{
${ }^{15}$ Az opciók listája (és opciókkal pedig maximálisan el van látva az én autóm + DIM) egyáltalán nem is jellemző a szerény A-típusra.

${ }^{16}$ Büszkén mutat az 58 éves férfi a külső fényszórókkal és összecsukható napernyővel ellátott ragyogó autóra + DIM.

${ }^{17}$ Tegnap Szafarikéknál volt egy kis tüz + DIM, de nem volt vészes.

18 Thomas Bucheli, a Svájci Meteorológiai Szolglat időjósa, napos időt ígért augusztus 28-ra. Legrosszabb esetben pár esőcsepp + DIM vagy egy zivatar + DIM úgy esete felé.
} 
13. Gyorsan felcserért futnak, de nincs semmi baj, mindössze petáknyi sebecske marad a homlokán, amitől nyugodtan mehet Freckre Öexcellenciája. (MNSZ2 2016. doc\#71, Nyírő, J., Madéfalvi veszedelem.)

A harmadik esetben a diminutívum denotátumához való viszonyulás negatív lesz:

14. Ей нравилось, как решительно и беспощадно изгнал он пронырливого господинчика. ${ }^{19}$ (RNC 2003-2016. Нагибин, Ю. М. (1972-1979): Трое и одна и еще один.)

15. Robert Beyers Gunther bleibt dreieinhalb Stunden lang das hilflose Königlein mit

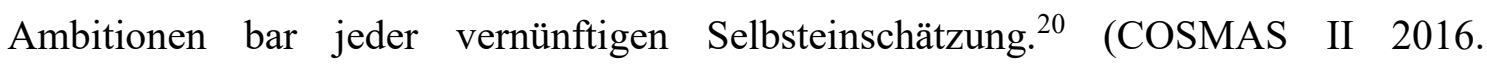
U09/SEP.02277 Süddeutsche Zeitung, 2009.15.09.)

16. Igen, mindezek régen meghirdetett elvek és törvények is, kettős szereppel: egyrészt, hogy bármely postaigazgató és személyzeti fönököcske felrúghassa mindahányat, másrészt, hogy bármely kritika esetén hivatkozni lehessen rájuk. (MNSZ2 2016. doc\#672. Sütő, András (2001): Fülesek és fejszések között.)

A fenti példák is mutatják azt a természetesen nem kizárólagos szabályt, hogy az élőlények (azaz inkább emberek) kicsinyített alakja negatív, a tárgyaké pedig inkább pozitív jelentéssel párosul (Szpiridonova 1999: 16-17). Ez nyilvánvalóan nem érvényes a személynevekre, amelyekhez diminutívumképzőt illesztve ritkábban valósul meg lenéző jelentés, sokkal inkább becézés vagy bizalmas beszédhelyzet teremtésére irányul a kicsinyítő szóképzés. A személynévből származtatott diminutívum így gyakran sajátos, gyengéd, illetve közvetlen szituációt kezdeményező vocativusként fogható fel (Würstle 1992: 190). A címzett közvetlen megszólításakor ez a funkció tünik a legjellegzetesebbnek, de ha a diminutívum a kommunikációs szituáción kívüli harmadik személyre vonatkozik, a megnyilatkozás néha inkább stilisztikai tartalmat hordoz, mintsem erős szubjektivitást vagy intimitást. Ehhez támpontot adhat az, ha a becézett keresztnév a vezetéknévvel együtt szerepel:

17. Я тогда: Андрей Петрович, хотите подойдем сейчас к Андрюше Миронову? ${ }^{21}$ (RNC 2003-2016. Ваншенкин, Константин (1998): Писательский клуб.)

\footnotetext{
${ }^{19}$ Tetszett neki, ahogy határozott és kegyetlen fellépéssel elkergette a cseles urat $+D I M$.

${ }^{20}$ Robert Beyers Gunther három és fél órán keresztül a tehetetlen király + DIM marad minden józan önértékelésnek híján lévő ambicióival.
} 
18. [A] hajdani Tuskirálynak sem derogált kigurított vörös szőnyeg mellett fogadni Szabó Petit, aki aztán a reflektorok fénycsóvájában, nyilvánvaló aluledzettsége ellenére, annak rendje s módja szerint legyőzte riválisát. (MNSZ2 2016. sajtócikk, doc\#1355)

Megfigyeléseim alapján sportolókat, sporttársakat bevettnek számít becézett keresztnévvel és családnévvel megnevezni, az oroszban is találunk példát:

19. Виши я проиграл в группе, но все-таки вышел в полуфинал, с Володей Крамником играл удачнее, чем обычно, но этого не хватило. ${ }^{22}$ (RNC 2003-2016, Шипов, Сергей (2004): Летние привычки олимпийцев Росии. (sic!) In: 64 Шахматное обозрение, 2004.08.15.)

Német korpuszban eddig nem találtam hasonló példát.

Nehezebb feladatunk van, ha azokat a szituációkat szeretnénk körbejárni, amelyekben a diminutívum használata a beszédhelyzetre vonatkozik. Dressler és Merlini Barbaresi (1994: 146-148) a következőket említi: játékosság vagy tréfás használat, enyhítés (pl. kérés, parancs) gyermek- vagy állatközpontú beszédhelyzet, irónia, érzelmi színezet (szeretet, szimpátia), intimitás kifejezése. Ezekre a diminutívum jelentésének általános vizsgálatánál már részben kitértünk. A teljesség igénye nélkül annyit tegyünk még hozzá az eddigiekhez, hogy bár a fentebb említett aktualizációk mindhárom nyelvben lehetségesek, az orosz beszélt nyelvben jóval gyakrabban jutnak érvényre, mint a németben vagy a magyarban. Ezt jelzi az is, hogy olyan félhivatalosnak tekinthető helyzetben, mint az orvosi vizsgálat vagy a vásárlás, az orosz természetességgel alkalmaz diminutívumokat: „Я вам сердечко послушаю//”; „Двести грам колбаски//, Десяток яичек//" (Zemszkaja et al. 1981: 113). A másik két nyelvben e mondatok tükörfordítása hasonló szituációban kevésbé magától értetődő.

A fejezet lényegét úgy fogalmazhatnánk meg, hogy a diminutívumok mindhárom vizsgált nyelvben nagyon hasonló jelentésekkel rendelkezhetnek. Az alábbi diagram foglalja össze, hogy az egyes nyelvekben jellemzően milyen szemantikai diminutívumjelentések fejlődtek ki:

\footnotetext{
${ }^{21}$ Én akkor azt mondtam: Andrej Petrovics, szeretné, hogy most elmenjünk Andrjusa Mironovhoz?

${ }^{22}$ Visi ellen vesztettem a csoportban, mégis kijutottam az elödöntőbe, aztán Vologya Kramnyik ellen jobban játszottam, mint általában, de ez nem volt elég.
} 


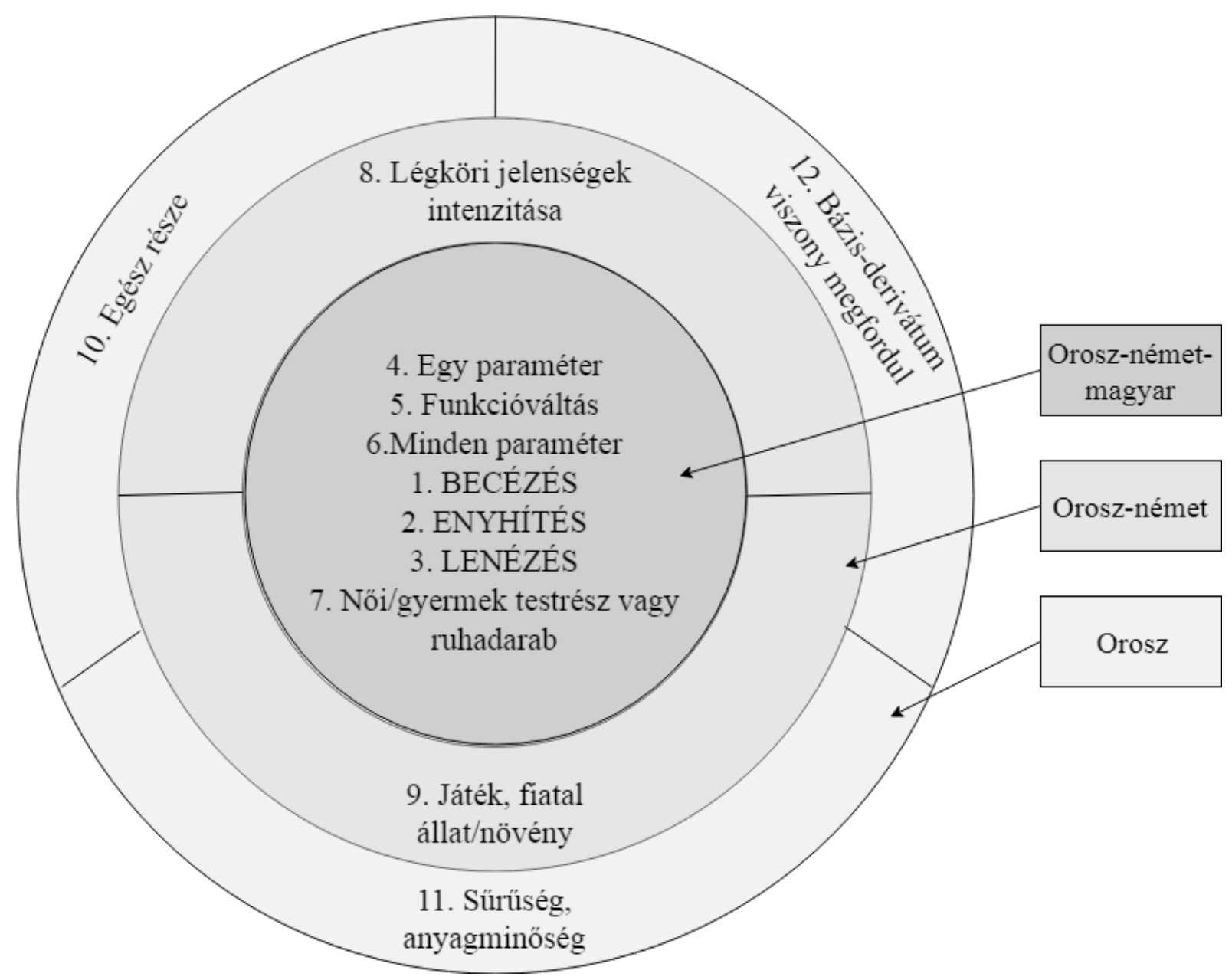

2. ábra. Szemantikai diminutívumjelentések az oroszban, németben és magyarban.

Vita tárgya lehet, hogy tökéletesen pontos-e a fenti csoportosítás, hiszen például nem teljesen egyértelmű, mennyire tekinthetjük számottevőnek a németben az itt 8-as vagy 9-es számmal jelölt jelentéseket. Ennek ellenére világos, hogy a legtöbb lehetőséget mindhárom nyelv kihasználja (lásd a központi kört). A különbség korántsem olyan nagy, mint arra a diminutívumokban felettébb gazdag orosz nyelv ismeretében számíthatnánk.

\section{5. Összegzés és kitekintés}

Foglaljuk össze legfontosabb tapasztalatainkat. Az orosz, német és magyar nyelvben egyaránt legalább két szuffixummal képezhetünk diminutívumokat. A derivációt korlátozzák hangtani szabályok és talán szemantikai megkötések is, jóllehet utóbbiakat a jellegzetes szubjektívevaluatív jelentések miatt nehéz volna pontosan megragadni. Az egyes nyelvek diminutívumképző szabályainak összhalmazát szóképzési alosztályoknak neveztük, és összehasonlítva ezeket az alosztályokat arra jutottunk, hogy a természetes morfológia kritériumrendszere szerint a legnagyobb mértékủ termékenységet az orosz deriváció mutatja, 
míg a német és a magyar közel azonos szinten áll. A nyelveken belül pedig megfigyelhettük a vizsgált toldalékmorfémák konkurenciáját, de világos, hogy némelyek közülük produktívabbak, mint a többi.

Az eltérő termékenység magyarázható diakrón szempontból. Előfordulhat, hogy valamelyik képző a nyelv időbeli változása során több morfémából állt össze, mint konkurens párja, ahogy a magyar $-(V) \operatorname{csk} A$ a $-k A$ szuffixummal szemben. Máskor a beszélők nyelvhasználati szokásai, hagyományai is komoly szerepet játszhatnak, ahogy a -chen és a -lein vizsgálata

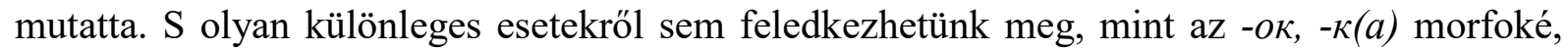
melyek gyakoriságuknak egykori alacsony mértéke és expresszivitásuknak megőrzése miatt válhattak később különösen elterjedtté.

Célszerünek véltük a diminutívumokat általánosan poliszém szavakként definiálni, melyek a bázis és a kontextus függvényében mértékbeli kicsinyítést, illetve becéző, enyhítő vagy lenéző jelentést fejezhetnek ki. E jelentések közül általában egyszerre több is érvényre jut, bár nem feltétlenül egyenlö mértékben. Konkrét beszédhelyzetben a diminutívumok különleges funkciót tölthetnek be azáltal, hogy magára a szituációra, a kommunikációs partnerek közötti viszonyra vonatkoznak, ekkor a pragmatikai jelentés elötérbe kerüléséről beszélhetünk. Láthattuk, hogy a kicsinyítés szemantikai potenciálja nem mutat rendkívüli különbséget a három nyelv között. Mégsem felejthetjük el, hogy e nyelvek beszélői nem azonos módon, nem ugyanazokban a szituációkban és nem ugyanolyan gyakran használnak diminutívumokat. A pragmatikai funkciók részletes leírása talán hozzájárulna a továbbiakban a különbségek magyarázatához, de e probléma megnyugtató megválaszolásához valószínűleg a nyelvi világképeket és az egyes kultúrákat is be kell vonni a vizsgálatba.

Végezetül pedig térjünk vissza a 2.4. pontban tett megállapításunkhoz, mely szerint az orosz tekintetében az idegen szavakból képzett, korpuszban megjelenő derivátumok és a nonszensz szavas kérdőívek eredményei többnyire olyan szuffixumokat mutatnak, melyek tipikusan kisebb expresszivitást adnak a képzett szónak, mint más, ritkábban előforduló morfémák. Emlékezzünk megjegyzésünkre a 4.1. pontban, amely szerint kapcsolat lehet egy diminutívumképző expresszív ereje és gyakorisága között. Érdekes, hogy a 4.2. pontban az Aval jelölt jelentésre hozott példák közt ugyanezek a „megszokottabb” morfémák tünnek fel. Ez logikus, hiszen a kisebb expresszív erővel bíró képző nagyobb eséllyel juttat kifejezésre elsősorban kis mértéket/méretet, mint szubjektív-evaluatív jelentést. E szuffixumok használata az oroszban könnyen betölthet pusztán stilisztikai szerepet is. Ebböl az következik, hogy az orosz diminutívumképzőket két csoportra oszthatjuk: 1) gyakoribb, kisebb expresszív 
erővel bírókra, valamint 2) ritkább, nagyobb expresszív erővel rendelkezőkre. Az első

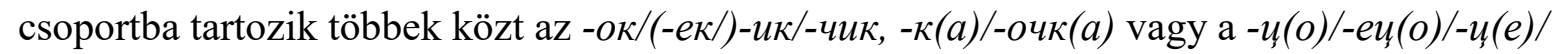
-uu(e), a másodikba pedig például az -yuк- és az -umк-. Ha szótárakban feltüntetnek diminutívumokat - mint „Az orosz nyelv szóképzési szótárában” (Tyihonov 1985) -, akkor azok valószínűleg az első csoport képzőivel létrehozott szavak lesznek. Bizonyára még egy harmadik csoportot is kijelölhetünk, melynek szuffixumai majdnem kizárólag vagy csak személynévi bázisokon produktívak (pl. $-y л(\Omega) /-y \mu(\Omega) /-y c(я) /-y u(a)$ ), esetleg Lopatyin (1982: 208-216) leírása óta már el is vesztették termékenységüket. Ha valóban csak becenévképzőként használhatók, úgy akár el is különíthetjük őket a diminutívumoktól.

A fentiekböl arra a feltevésre juthatunk, hogy a német és magyar diminutívumképzők gyakoriságuk (sőt talán produktivitásuk) alapján, illetve annak valószínűsége szerint, hogy a velük képzett szavak szubjektív-evaluatív jelentésben (ez voltaképpen orosz elnevezéssel „ласкательное/уничижительное значение”) fognak aktualizálódni, az 1) és 2) orosz képzőcsoport között helyezkednek el. Ez azonban természetesen nem bizonyított tény, inkább egy hipotézis, melyre a jelen tanulmány következtetni enged. Az ellenőrzés további részletes vizsgálatokat igényelne, például párhuzamos korpuszok segítségével: ha nagy mennyiségü adat alapján a 2) típusú orosz diminutívumnak észrevehetően több német vagy magyar kicsinyítő képzős szó felel meg, mint az 1) típusúnak - utóbbiak inkább analitikus szerkezetekkel vagy egyszerüen a diminutívumképző hiányával lesznek párhuzamba állíthatók -, akkor a feltételezés beigazolódni látszik. Mindezek a feltevések persze túlmutatnak jelen munkánk keretein, mindazonátal támpontul szolgálhatnak a diminutívumok további tanulmányozásához.

\section{Irodalomjegyzék}

Delhay, Corinne (1995): Le diminutif: la diminution sans comparaison? [A diminutívum: kicsinyítés összehasonlítás nélkül?] In: Faits de langues 3 (5), 63-72. URL: http://www.persee.fr/doc/flang_1244-5460_1995_num_3_5_976 [Letöltés dátuma: 2016.11.14.].

Dressler, Wofgang U./Merlini Barbaresi, Lavinia (1994): Morphopragmatics. Diminutives and Intensifiers in Italian, German, and Other Languages. [Morfopragmatika. Kicsinyítők és fokozók az olasz, német és más nyelvekben.] Berlin, New York: de Gruyter (= Trends in Linguistics. Studies and Monographs 76), https://doi.org/10.1023/A:1014010530824

Dressler, Wolfgang U./Ladányi, Mária (2000): Productivity in word formation (WF): A morphological approach. [Produktivitás a szóképzésben: Morfológiai megközelítés.] In: 
Acta Linguistica Hungarica 47 (1-4), 103-144. URL: real-j.mtak.hu/851/1 /ACTALINGV_47.pdf.

É. Kiss, Katalin/Kiefer, Ferenc/Siptár, Péter (2003): Új magyar nyelvtan. 3. kiadás. Budapest: Osiris Kiadó.

Fleischer, Wolfgang/Barz, Irmhild (2012): Wortbildung der deutschen Gegenwartssprache. [A mai német nyelv szóképzése.] 4., átdolgozott kiadás. Berlin/Boston: de Gruyter.

Hentschel, Elke/Weydt, Harald (2013): Handbuch der deutschen Grammatik. [A német nyelvtan kézikönyve.] 4., átdolgozott kiadás. Berlin/Boston: de Gruyter.

Henzen, Walter (1965): Deutsche Wortbildung. [Német szóképzés.] 3., átnézett és bővített kiadás. Tübingen: Max Niemeyer.

Jurafsky, Daniel (1996): Universal Tendencies in the Semantics of the Diminutive. [Univerzális tendenciák a diminutívum szemantikájában.] In: Language 72 (3), 533-578. URL: http://www.jstor.org/stable/416278, https://doi.org/10.2307/416278

Keszler, Borbála (2000): A szóképzés. In: Keszler, Borbála (főszerk.): Magyar Grammatika. Budapest: Nemzeti Tankönyvkiadó, 307-320.

Kiefer, Ferenc (2007): Jelentéselmélet. 2., bővített és javított kiadás. Budapest: Corvina Kiadó.

Kiefer, Ferenc/Ladányi, Mária (2000a): A szóképzés. In: Kiefer, Ferenc (szerk.): Strukturális magyar nyelvtan. 3. kötet. Morfológia. Budapest: Akadémiai Kiadó, 137-164.

Kiefer, Ferenc/Ladányi, Mária (2000b): Morfoszintaktikailag semleges képzések. In: Kiefer, Ferenc (szerk.): Strukturális magyar nyelvtan. 3. kötet. Morfológia. Budapest: Akadémiai Kiadó, 165-214.

Kiparsky, Valentin (1975): Russische historische Grammatik. Band III. Entwicklung des Wortschatzes. [Orosz történeti nyelvtan. III. kötet. A szókincs fejlődése.] Heidelberg: Carl Winter Universitätsverlag.

Ladányi, Mária (2007): Produktivitás és analógia a szóképzésben: elvek és esetek. Budapest: Tinta Könyvkiadó (= Segédkönyvek a nyelvészet tanulmányozásához 76).

Oravecz, Csaba/Váradi, Tamás/Sass, Bálint (2014): The Hungarian Gigaword Corpus. In: Proceedings of LREC 2014. URL: http://www.lrec-conf.org/proceedings/lrec2014 /pdf/681_Paper.pdf [Letöltés dátuma: 2017.12.04.].

Paul, Hermann (1957): Deutsche Grammatik. Band V. Wortbildungslehre. [Német nyelvtan. V. kötet. Szóképzéstan.] 3. kiadás. Halle (Saale): VEB Max Niemeyer Verlag. 
Plank, Frans (1981): Morphologische (Ir-)Regularitäten. Aspekte der Wortstrukturtheorie. [Morfológiai szabály(talanság)ok. A szóstruktúra-elmélet aspektusai.] Tübingen: Gunter Narr Verlag (= Studien zur deutschen Grammatik 13).

Scheidweiler, Gaston (1984/85): Zur Konnotation der Diminutivsuffixe -chen und -lein. [A -chen és -lein kicsinyítő képzők konnotációjához.] In: Muttersprache 95 (1-2), 69-79.

Szegfü, Mária (1991): A névszóképzés. In: Benkő, Loránd (főszerk.): A magyar nyelv történeti nyelvtana I. A korai ómagyar kor és előzményei. Budapest: Akadémiai Kiadó, $188-258$.

Szegfü, Mária (1992): A névszóképzés. In: Benkő, Loránd (főszerk.): A magyar nyelv történeti nyelvtana II/1. A kései ómagyar kor. Morfematika. Budapest: Akadémiai Kiadó, 268-320.

Würstle, Regine (1992): Überangebot und Defizit in der Wortbildung. [Túlkínálat és hiány a szóképzésben.] Frankfurt am Main: Peter Lang (= Bonner romanistische Arbeiten 42).

Zsemlyei, Borbála (2011): Kicsinyítő képzők az erdélyi régiségben. Kolozsvár: Erdélyi Múzeum-Egyesület.

Avaneszov (1968)

Аванесов, Р. И. (1968): К истории чередования согласных при образовании уменьшительных существительных в праславянском. [A mássalhangzó-váltakozások történetéhez a kicsinyítő főnevek képzésénél az ősszlávban.] In: Виноградов, В. В./Бернштейн, С. Б./Толстой, Н. И. (szerk.): Славянское языкознание. VI международный съезд славистов (Прага, август 1968 г.). Доклады советской делегации. [Szláv nyelvészet. A szlavisták VI. nemzetközi ülése (Prága, 1968 augusztusa). A szovjet delegáció előadásai.] Москва: Издательство «Наука», 3-18.

Zemszkaja/Kitajgorodszkaja/Sirjajev (1981)

Земская, Е. А./Китайгородская, М. В./Ширяев, Е. Н. (1981): Русская разговорная речь. Общие вопросы. Словообразование. Синтаксис. [Orosz köznyelv. Általános kérdések. Szóképzés. Szintaxis.] Москва: Издательство «Наука».

Rahilina (1994)

Рахилина, Е. В. (1994): Семантика размера. [A méret szemantikája.] In: Семиотика и информатика 34, 58-81. Letöltés dátuma: 2016.11.03. URL: http://pcs.math. msu.su/ uspensky/journals/siio/34/34_03_RAHILINA.pdf

Szpiridonova (1999) 
Спиридонова, Н. Ф. (1999) Русские диминутивы: Проблемы образования и значения. [Orosz diminutívumok: A képzés és jelentés problémái.] In: Известия Российской академии наук, Серия литературы и языка 58 (2), 13-22.

Lopatyin (1982)

Лопатин, В. В. (1982): Словообразование имен существительных. [Főnévképzés.] In: Шведова, Н. Ю. (főszerk.): Русская грамматика I. [Orosz nyelvtan I.] Москва: Издательство «Наука», 142-269.

Svedova/Lopatyin (1989)

Шведова, Н. Ю./Лопатин, В. В. (szerk.) (1989): Краткая русская грамматика. [Rövid orosz nyelvtan.] Москва: Издательство «Русский язык».

\section{Szótárak:}

Baer, Dieter/Wermke, Matthias (szerk.) (2000): Das große Fremdwörterbuch. Herkunft und Bedeutung der Fremdwörter. [Az idegen szavak nagy szótára. Az idegen szavak eredete és jelentése.] 2., átdolgozott és bővített kiadás. Mannheim, Leipzig, Wien, Zürich: Dudenverlag.

Bakos, Ferenc (főszerk.) (2013): Idegen szavak és kifejezések szótára. 3. kiadás. Budapest: Akadémiai Kiadó.

Mater, Erich (1970): Rückläufiges Wörterbuch der deutschen Gegenwartssprache. [A mai német nyelv szóvégmutató szótára.] Harmadik kiadás. Leipzig: VEB Verlag Enzyklopädie.

Jegorova (2014)

Егорова, Т. В. (2014): Словарь иностранных слов современного русского языка. [A mai orosz nyelv idegen szavainak szótára.] Москва: Издательство «Аделант».

Lazova (1974)

Лазова, М. В. (főszerk.) (1974): Обратный словарь русского языка. [Az orosz nyelv szóvégmutató szótára.] Москва: Издательство «Советская Энциклопедия».

Tyihonov (1985)

Тихонов, А. Н. (1985): Словообразовательный словарь русского языка в двух томах. [Az orosz nyelv szóképzési szótára két kötetben.] Москва: Издательство «Русский язык».

\section{Korpuszok:}

COSMAS II $\mathrm{web}_{\mathrm{w}}$, Version 2.2 (2016): Corpus Search, Management and Analysis System. Betriebssystemunabhängige WWW-Applikation. Institut für Deutsche Sprache. URL: https://cosmas2.ids-mannheim.de/cosmas2-web/ 
Initium 1 (2019)

MNSZ2, v2.0.4 (2016): Magyar Nemzeti Szövegtár. MTA Nyelvtudományi Intézet, Nyelvtechnológiai Kutatócsoport. URL: http://clara.nytud.hu/mnsz2-dev/

RNC (2003-2016): Национальный корпус русского языка./Russian National Corpus. Институт русского языка им. В. В. Виноградова РАН, Отдел корпусной лингвистики и лингвистической поэтики. URL: http://ruscorpora.ru/. 


\section{Melléklet}

Az alábbi táblázatokban a nonszensz szavas kérdőívek eredményeit láthatjuk. A fejlécben mindig a bázisok szerepelnek. Az egyes sorokban a képzett szavak láthatóak, a tőlük jobbra álló számok azt jelzik, hányszor adták meg az adott alakot a különböző válaszadók. Az itt feltüntetett átdolgozott táblázatokból töröltem az értékelhetetlen adatokat. Az orosz kérdőíveken megadott instrukcióknak megfelelően sok válaszadó jelölte a hangsúlyt a derivátumokban. A hangsúlyjelölést csak -ýmк- szuffixumon hagytam meg, elkülönítendő a hangsúlytalan -yuк- képzőtől. A három, orosz anyanyelvi beszélőknek szánt kérdőív adatait az értékelés során összesítve kezeltem, itt mindazonáltal elkülönítve láthatjuk őket.

\section{Orosz I}

\begin{tabular}{|c|c|c|c|c|c|c|c|c|c|}
\hline \multicolumn{2}{|l|}{ ба́па } & \multicolumn{2}{|l|}{ бруж } & \multicolumn{2}{|l|}{ вилго́рф } & \multicolumn{2}{|l|}{ внези́шк } & \multicolumn{2}{|l|}{ врощ } \\
\hline бапака & 1 & бружечек & 1 & вилгорфик & 10 & внезишек & 1 & врощаня & 1 \\
\hline бапачка & 1 & бружечёк & 1 & вилгорфка & 1 & внезишечка & 2 & врощёнушек & 1 \\
\hline бапачок & 2 & бружечка & 2 & вилгорфушек & 1 & внезишик & 1 & врощечка & 1 \\
\hline бапашечек & 1 & бружик & 4 & вилгорфушка & 3 & внезишка & 2 & врощик & 13 \\
\hline бапашка & 1 & бружичка & 2 & вилгорфчик & 2 & внезишкик & 2 & врощка & 1 \\
\hline бапик & 1 & бружка & 1 & & & внезишкичек & 1 & врощок & 1 \\
\hline бапочик & 1 & бружок & 5 & & & внезишко & 5 & врощочка & 1 \\
\hline бапочка & 8 & бружочек & 1 & & & внезишкочек & 1 & врощчка & 1 \\
\hline бапочко & 1 & буржочик & 1 & & & внезишкочка & 1 & & \\
\hline бапушка & 1 & & & & & внезишкуша & 1 & & \\
\hline бапчик & 1 & & & & & внезишкушка & 2 & & \\
\hline & & & & & & внезишкчик & 1 & & \\
\hline & & & & & & внезишок & 2 & & \\
\hline
\end{tabular}




\begin{tabular}{|c|c|c|c|c|c|c|c|c|c|}
\hline \multicolumn{2}{|l|}{ ви́геребеч } & \multicolumn{2}{|l|}{ дагари́н } & \multicolumn{2}{|l|}{ допо́зм } & \multicolumn{2}{|l|}{ дрезёмлец } & \multicolumn{2}{|l|}{ евдо́пус } \\
\hline выгеребечек & 1 & дагаринка & 3 & допозмик & 11 & дреземленчик & & 1 евдопусек & 1 \\
\hline выгеребечик & 5 & дагаринок & 3 & допозмиченек & 1 & дрезёмлеца & & 1 евдопусечка & 1 \\
\hline выгеребечка & 2 & дагариночек & 1 & допозмичка & 1 & дреземлецижек & & 1 евдопусик & 9 \\
\hline выгеребечко & 2 & дагаринушек & 1 & допозмишек & 1 & дреземлецик & & 2 евдопусичек & 2 \\
\hline выгеребечок & 1 & дагаринушка & 2 & допозмок & 1 & дрезёмлецица & & 1 евдопуска & 1 \\
\hline выгеребечушка & 1 & дагаринушко & 1 & допозмочка & 1 & дрезёмлецичек & & 1 евдопусчик & 2 \\
\hline выгеребчик & 2 & дагаринчик & 6 & допозмульчик & 1 & дреземлецка & & 1 евдопуська & 1 \\
\hline выгребечик & 2 & дагариныш & 1 & допозмушка & 2 & дрезёмлецко & 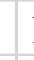 & 1 & \\
\hline выгребечка & 1 & дагароночка & 1 & допозмышек & 1 & дреземлецок & 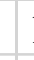 & 1 & \\
\hline \multirow[t]{8}{*}{ выгребечок } & 1 & дапаринчик & 1 & & & дрезёмлецок & 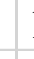 & 1 & \\
\hline & & & & & & дреземлецунчик & 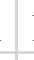 & 1 & \\
\hline & & & & & & дрезёмлецушек & 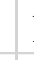 & 1 & \\
\hline & & & & & & дреземлецушка & & 3 & \\
\hline & & & & & & дреземлечик & 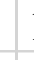 & 1 & \\
\hline & & & & & & дрезёмлечик & 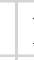 & 1 & \\
\hline & & & & & & дрезёмлик & & 1 & \\
\hline & & & & & & дрезёмлюшка & & 1 & \\
\hline \multicolumn{2}{|l|}{ ещезо́ль } & \multicolumn{2}{|l|}{ зламу́г } & \multicolumn{2}{|l|}{ злюбоду́н } & \multicolumn{2}{|l|}{ издю́лн } & \multicolumn{2}{|l|}{ илотро́м } \\
\hline ещезолечка & 1 & зламугик & 3 & злободунчик & 2 & издюлнек & 1 & илотромик & 6 \\
\hline ещезолик & 4 & зламугичка & 1 & злюбодунечка & 1 & издюлнец & 1 & илотромок & 1 \\
\hline ещезолька & 3 & зламугок & 2 & злюбодуник & 1 & издюлник & 4 & илотромушка & 2 \\
\hline ещезольчик & 5 & зламуголичек & 1 & злюбодуничек & 1 & издюлник & 1 & илотромчик & 7 \\
\hline ещезольщичек & 1 & зламугочка & 1 & злюбодунок & 2 & издюлнок & 3 & & \\
\hline ещезолюшка & 2 & зламугушка & 2 & злюбодуношка & 1 & издюлночек & 1 & & \\
\hline ещезолюшко & 1 & зламугушко & 1 & злюбодунушка & 1 & издюлнушко & 1 & & \\
\hline \multirow[t]{4}{*}{ ещещольчик } & 1 & зламугчик & 2 & злюбодунчик & 7 & 7 издюлнчик & 1 & & \\
\hline & & зламужек & 1 & злюбодюнько & 1 & издюлнюшек & 1 & & \\
\hline & & зламужичек & 1 & & & издюльник & 1 & & \\
\hline & & зламужка & 1 & & & излюдинцо & 1 & & \\
\hline
\end{tabular}




\begin{tabular}{|c|c|c|c|c|c|c|c|c|c|c|c|c|c|}
\hline \multicolumn{3}{|l|}{ кирдь } & \multicolumn{3}{|c|}{ кре́чник } & \multicolumn{3}{|c|}{ ктреф } & \multicolumn{3}{|c|}{ кудла́ш } & \multicolumn{2}{|l|}{ лорх } \\
\hline \multicolumn{2}{|l|}{ кидрушка } & \multirow{2}{*}{\begin{tabular}{|l|l}
1 & $\mathrm{~K}$ \\
3 &
\end{tabular}} & \multicolumn{3}{|c|}{ кречниковчик } & \multicolumn{3}{|l|}{ ктрефик } & \multicolumn{2}{|l|}{ кудлаша } & \multirow{2}{*}{$\begin{array}{l}1 \\
2\end{array}$} & \multirow{2}{*}{$\begin{array}{l}\text { лорхик } \\
\text { лорховик }\end{array}$} & \multirow{2}{*}{$\begin{array}{l}8 \\
1\end{array}$} \\
\hline кирдик & & & \multicolumn{2}{|c|}{ кречникуша } & 1 & \multicolumn{3}{|c|}{ ктрефинка } & \multicolumn{2}{|c|}{ кудлашек } & & & \\
\hline кирдичик & & 1 & \multicolumn{2}{|c|}{ кречникушка } & $\begin{array}{ll}a & 1\end{array}$ & \multicolumn{3}{|c|}{ ктрефичек } & \multicolumn{2}{|c|}{ кудлашечка } & 2 & лорхок & 1 \\
\hline кирдишко & & 1 & \multicolumn{2}{|c|}{ кречникушко } & 0 & \multicolumn{3}{|l|}{ ктрефок } & 3 кудлаши & & 8. & лорхочка & 1 \\
\hline кирдок & & 1 & кречникче & & 1 & ктрефуш & Іек & & 1 кудлаши & инка & 1 & лорхуша & 1 \\
\hline кирдушко & & 1 & кречничек & & 9 & ктрефуш & Іка & & 3 кудлашкء & & 1. & лорхушек & 1 \\
\hline кирдышечка & & 1 & кречничек & & 1 & ктрефчи & & & 3 кудлашкс & & 1 & лорхушка & 2 \\
\hline кирдьчик & & 1 & кречничок & & 1 & ктрефюц & шечі & Іка & 1 кудлашог & & 2. & лорхчик & 1 \\
\hline кирдьячок & & 1 & кречнише & & 1 & & & & & & & лохушка & 1 \\
\hline кирдьяшечка & & 1 & & & & & & & & & & & \\
\hline кирдюлик & & 1 & & & & & & & & & & & \\
\hline кирдюнешеч & чка & 1 & & & & & & & & & & & \\
\hline кирдючок & & 1 & & & & & & & & & & & \\
\hline кирдюшка & & 1 & & & & & & & & & & & \\
\hline кирдявчик & & 1 & & & & & & & & & & & \\
\hline кирдяшка & & 1 & & & & & & & & & & & \\
\hline ма́лщик & & & млёнь & & & мырано́к & & & мы́ісолш & & & нюлп & \\
\hline малщик & & $1 \mathrm{~N}$ & мленец & 1 & мыр & ранокочка & \begin{tabular}{l|l} 
a & 1
\end{tabular} & $1 \mathrm{M}$ & ұысолншок & & $1 \mathrm{HI}$ & нюлпачок & 1 \\
\hline малщикик & & $1 \mathrm{~N}$ & млёник & 2 & мыр & ранокуше & & $1 \mathrm{M}$ & иысолчик & & $1 \mathrm{HI}$ & Іюлпик & 9 \\
\hline малщикок & & $1 \mathrm{~N}$ & млёнок & 1 & мыр & ранокушк & & $1 \mathrm{M}$ & џысолшаськ & & $1 \mathrm{Hr}$ & ıюлпочек & 2 \\
\hline малщикучик & & $1 \mathrm{~N}$ & млёночек & 1 & мыр & ранокчик & & $2 \mathrm{M}$ & иысолшеньк & & $1 \mathrm{HI}$ & Іюлпочка & 2 \\
\hline малщикце & & $1 \mathrm{~N}$ & млёнчик & 1 & мыр & ранокчук & & $1 \mathrm{M}$ & иысолшечка & & $1 \mathrm{Hr}$ & ююлпушка & 1 \\
\hline малщикчек & & $1 \mathrm{~N}$ & млёнька & 2 & мыр & раночек & & $7 \mathrm{M}$ & иысолшик & & $6 \mathrm{Hr}$ & Іюлпчик & 1 \\
\hline малщикышк & & $1 \mathrm{~N}$ & мленьчек & 1 & мыр & раночка & & $1 \mathrm{M}$ & иысолшик & & 1 & & \\
\hline малщицко & & $1 \mathrm{~N}$ & мленьчик & 2 & мыр & ранчик & & $2 \mathrm{M}$ & иысолшка & & 1 & & \\
\hline малщичек & & $7 \mathrm{~N}$ & млёньчик & 2 & & & & & иысолшунчи & & 1 & & \\
\hline малшичок & & $2 N$ & млёнюшка & 1 & & & & & ұысолышка & & 1 & & \\
\hline & & & мненок & 1 & & & & & & & & & \\
\hline ня́кож & & & окла́м & & & олокро́з & & & отрыка́зд & & & пёнгарь & \\
\hline някожек & 1 & окл & ламик & $4 \mathrm{o}$ & ол & розик & 10 & & рыказдец & 1 I & пён & нгарёк & 2 \\
\hline някожечек & $1 c$ & окл & ламиночка & 10 & рлокр & розко & 1 & отр & рыказдик & 10 I & пен & нгарёночек & 1 \\
\hline някожечка & 1 & окл & ламка & 10 & олокр & розничек & 1 & отр & рыказдичек & 1 I & пен & нгареточка & 1 \\
\hline някожик & $6 c$ & окл & ламочек & 10 & рлокр & розочек & 1 & & рыказдок & 1 I & пен & нгарик & 3 \\
\hline някожинчик & $1 c$ & окл & ламочка & 20 & рлокр & розочка & 1 & & рыказдочек & 1 I & пён & нгарик & 3 \\
\hline някожка & $3 c$ & окл & ламушек & 10 & рлокр & розушка & 1 & отр & рыказдочка & 1 I & пен & нгарчик & 1 \\
\hline някожушка & $1 c$ & окл & ламушка & 10 & олокр & розчик & 1 & отр & рыказдчик & 1 I & пён & нгарчик & 1 \\
\hline някожушко & 1 & окл & ламчик & 5 & & & & & & & пен & нгарька & 1 \\
\hline & & & & & & & & & & & пен & нгарьчик & 2 \\
\hline & & & & & & & & & & & пён & нгарьчик & 1 \\
\hline
\end{tabular}




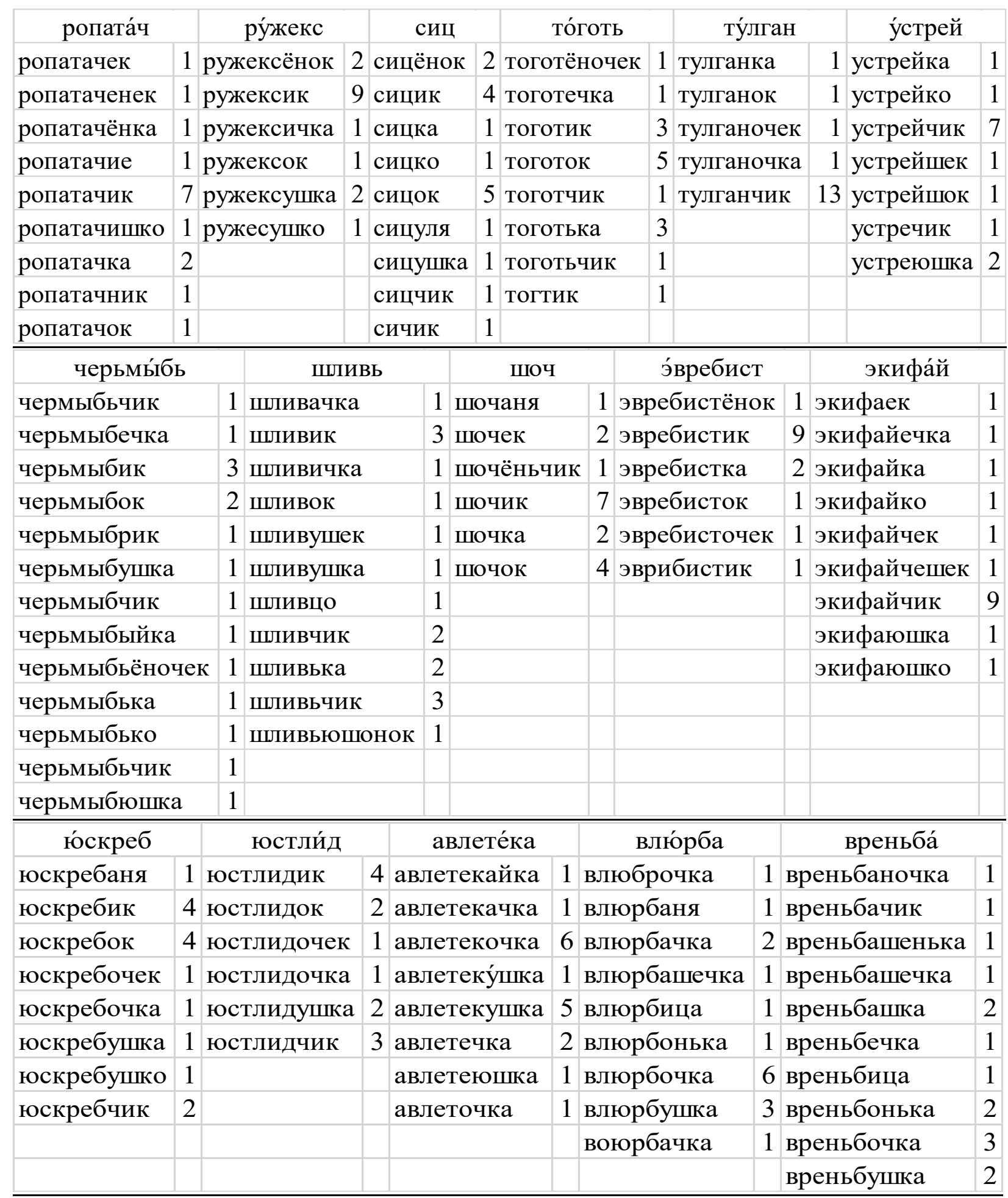




\begin{tabular}{|c|c|c|c|c|c|c|c|c|c|c|}
\hline \multicolumn{2}{|l|}{ вы́ба } & \multicolumn{3}{|c|}{ гилталя́ } & \multicolumn{2}{|l|}{ ди́фочка } & \multicolumn{2}{|l|}{ ди́фушка } & \multicolumn{2}{|l|}{ ехлю́нна } \\
\hline выбайка & \multicolumn{3}{|c|}{ гилталенька } & \multicolumn{2}{|c|}{ дифоня } & \multicolumn{2}{|r|}{ дивонька } & \multicolumn{2}{|r|}{ ехлюнначик } & 1 \\
\hline выбалочка & $1 \Gamma$ & \multicolumn{2}{|c|}{ гилталица } & \multicolumn{2}{|c|}{ дифочечка } & \multicolumn{2}{|r|}{ дифужек } & $1 \mathrm{e}$ & ехлюннашка & 2 \\
\hline выбанька & $1 \Gamma$ & \multicolumn{2}{|c|}{ гилталочка } & \multicolumn{2}{|c|}{ дифочка } & \multicolumn{2}{|r|}{ дифушечка } & \multicolumn{2}{|r|}{ ехлюннек } & 1 \\
\hline выбаушка & \multicolumn{3}{|c|}{ гилталушка } & \multicolumn{2}{|c|}{ дифочканька } & \multicolumn{2}{|r|}{ дифушица } & \multicolumn{2}{|r|}{ ехлюнночка } & 7 \\
\hline выбачик & $1 \Gamma$ & \multicolumn{2}{|c|}{ гилталька } & \multicolumn{2}{|c|}{ дифочкаушка } & \multicolumn{2}{|r|}{ дифушка } & $1 \mathrm{e}$ & ехлюннушка & 3 \\
\hline выбачка & $1 \Gamma$ & \multicolumn{2}{|c|}{ гилталюшка } & \multicolumn{2}{|r|}{ дифочкашка } & 1 д & дифушкачик & $1 \mathrm{e}$ & ехлюнньюшка & 1 \\
\hline выбашка & $1 \Gamma$ & гил & таляйка & 1 дІ & ифочкуша & 1 д & дифушкачка & $1 \mathrm{e}$ & ехлюночка & 1 \\
\hline выбка & $4 \Gamma$ & гил & таляночка 1 & 1 дІ & ифочку́шка & 1 д & дифушконька & $1 \mathrm{e}$ & ехлюнушка & 1 \\
\hline выбочка & $4 \Gamma$ & гил & талянчик & 1 дІ & ифочонка & 1 д & дифушкочка & 1 & & \\
\hline выбушка & $2 \Gamma$ & гил & таляня & 1 дІ & ифочушка & 1 д & дифушочка & 1 & & \\
\hline & & гил & талячка & 1 ді & ифошечка & 2 д & дифушушка & 1 & & \\
\hline & & гил & таляша & 1 ді & ифушенька & 1 & & & & \\
\hline & & гил & таляшечка 1 & 1 дІ & ифчоночка & 2 & & & & \\
\hline & & гил & таляшка & 2 & & & & & & \\
\hline & & гил & таляюшка 1 & 1 & & & & & & \\
\hline жёлостуц & шка & & жило́здь & & зомильня́ & & ки́чица & & ме́шща & \\
\hline желостуньк & & 1 & дилоздица & 1 & иленька & & 1 кичица & & 1 мешечка & 1 \\
\hline желостушең & ька & 1 & жилозденька & 1 & зомильница & & 3 кичицайка & & 1 мешщавка & 1 \\
\hline желостушеч & & 5 & жилоздец & 1 & зомильничка & & 1 кичицаняше & чка & 1 мешщавушка & 1 \\
\hline жёлостушеч & & 3 & жилоздечка & 2 & зомильнушка & & 2 кичицаушка & & 1 мешщайка & 1 \\
\hline жёлостушка & чик & 1 & жилоздик & 1 & зомильнюшка & & 1 кичиценька & & 3 мешщаня & 1 \\
\hline желостушка & чка & 1 & жилоздочка & 2 & зомильнявка & & 1 кичицка & & 1 мешщачик & 1 \\
\hline жёлостушка & чка & 1 & жилоздушка & 1 & зомильнячик & & 1 кичицочка & & 1 мешщачка & 1 \\
\hline жёлостушоч & & 1 & жилоздька & 2 & зомильняша & & 1 кичицошка & & 1 мешщашечка & 1 \\
\hline & & & жилоздьушка & a 1 & зомильняшечк & & 1 кичицуня & & 2 мешщица & 1 \\
\hline & & & жилоздьчик & 1 & зомильняшка & & 4 кичицушка & & 2 мешщичка & 1 \\
\hline & & & жилоздюнька & a 1 & & & кичичка & & 1 мешщочка & 1 \\
\hline & & & жилоздюшка & 2 & & & кичишка & & 1 мешщушка & 2 \\
\hline & & & & & & & & & мешщущечка & 1 \\
\hline
\end{tabular}




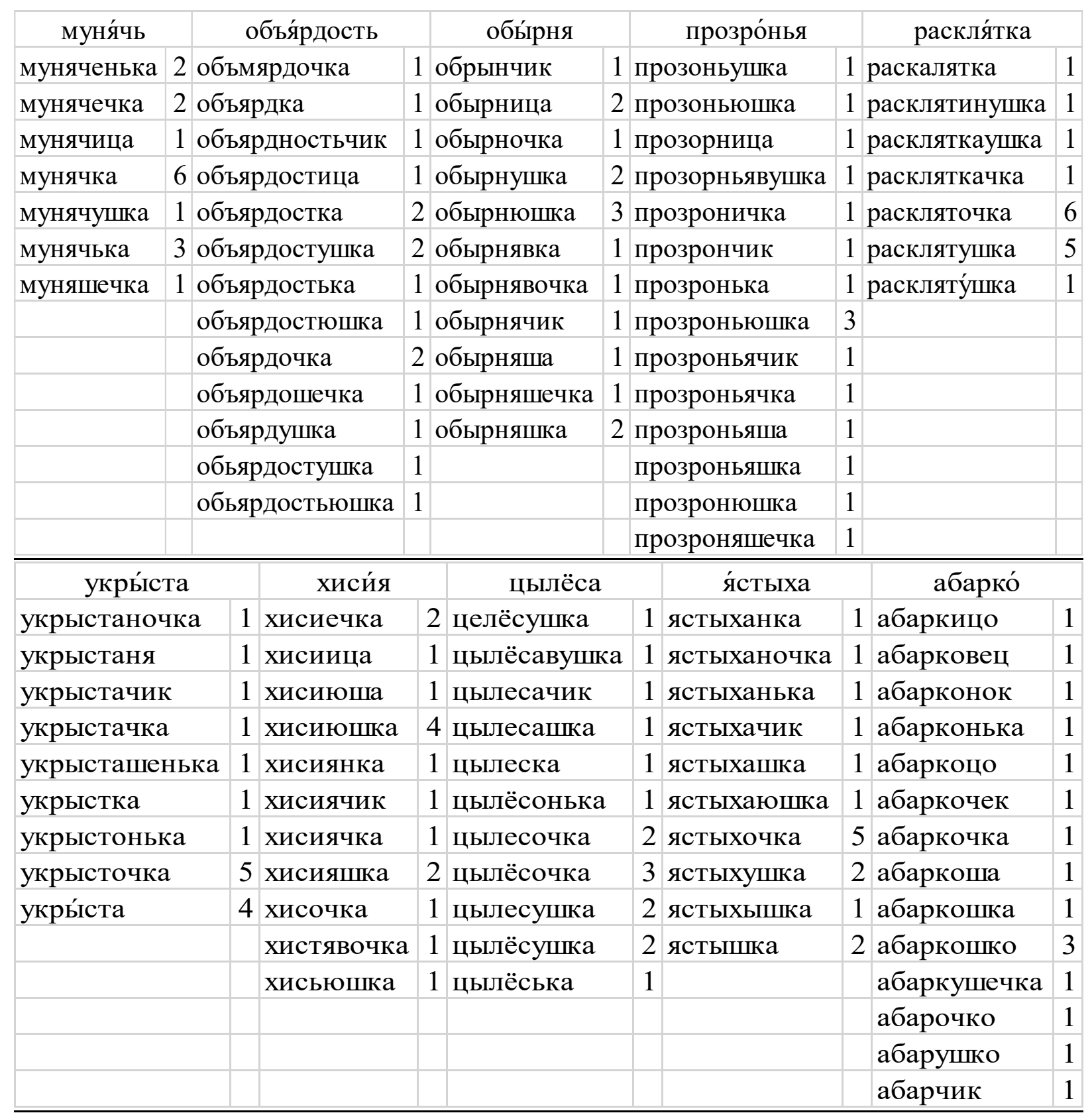




\begin{tabular}{|c|c|c|c|c|c|c|c|c|c|c|c|c|c|c|c|c|}
\hline \multicolumn{3}{|l|}{ а́вромле } & \multicolumn{3}{|c|}{ бара́тице } & \multicolumn{3}{|c|}{ бра́то } & \multicolumn{4}{|c|}{ бы́лыздо } & \multicolumn{3}{|c|}{ вальто́ } & \\
\hline \multicolumn{2}{|l|}{ авромилеще } & 16 & \multicolumn{2}{|c|}{ баратиня } & 1 & \multicolumn{2}{|c|}{ братец } & 1 & \multicolumn{3}{|c|}{ былыздец } & \multicolumn{3}{|c|}{ вальтицо } & 1 & \\
\hline \multicolumn{2}{|l|}{ авромлеец } & 1 & \multicolumn{3}{|c|}{ баратицевец } & \multicolumn{2}{|c|}{1 братишко } & 1 & \multicolumn{3}{|c|}{ былыздишко } & \multicolumn{3}{|c|}{ вальтишко } & 1 & \\
\hline \multicolumn{2}{|l|}{ авромлеко } & \multicolumn{4}{|c|}{ б баратицечик } & \multicolumn{2}{|c|}{ братко } & 3 & \multicolumn{3}{|c|}{ былыздко } & \multicolumn{3}{|c|}{ вальток } & 1 & \\
\hline \multicolumn{2}{|l|}{ авромленка } & \multicolumn{4}{|c|}{ б баратицешка } & \multicolumn{2}{|c|}{ браток } & 1 & \multicolumn{3}{|c|}{ былыздовец } & \multicolumn{3}{|c|}{ вальтонюшко } & 1 & \\
\hline авромленько & & 1 & баратицг & & 3 & братон & Іько & o 1 & былыз & здо & нька & 1 ва & аль & ьтоцо & 1 & \\
\hline авромлеце & & 1 & бар & & 1 & брат & & 1 & был & o & нько & 1 ва & аль & ьточик & 1 & \\
\hline авромлечик & & 1 & баратицу́ & у́шка & 1 & браточ & Іик & 1 & был & $\mathrm{O}$ & Ня & 1 ва & аль & ьточка & 1 & \\
\hline авромлечко & & 1 & бар & ушко & 2 & бра & гка & 1 & былыз & $\mathrm{O}$ & чик & 1 ва & аль & ІКО & 2 & \\
\hline авромлешко & & 2 & бa & & 1 & бра & шка & 2 & был & o & & 1 ва & аль & Co & 4 & \\
\hline авромлеюшк & & 1 & бap & Іечко & 1 & бра & шко & 2 & был & & & 1 ва & аль & ка & 2 & \\
\hline авромлко & & 1 & ба & If & 1 & 6 & шка & 1 & 6 & o & ко & 3 ва & 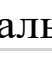 & & 1 & \\
\hline авромлюшко & & 2 & бap & & 1 & бра & шко & 1 & былыз & y & Іко & 1 & & & & \\
\hline авромляшечк & & 1 & & & & & & & был & 4 & & 1 & & & & \\
\hline & & & & & & & & & былыз & (1) & ШКо & 1 & & & & \\
\hline врь́іколо & & & дасcé & & & це & & & зыдро́ & & лых & жо́ & & мим & ние & \\
\hline вкрылошко & 1 & дас & ссейко & $13 a$ & ipen & ицецо & 13 & зыдр & рецо & 1 & лыжец & & 1 & мимолиянг & ьице & 1 \\
\hline врыколко & 2 & дас & ссеко & $13 a$ & $\mathrm{pp}$ & ценько & 23 & зыдр & рок & 1 & лыжка & & 1 & мимолчни & & 1 \\
\hline врыколоцо & 1 & дас & ссенчик & 13 & & 0 & 13 & зыдр & ронько & 1 & лыжко & & 2 & Ми & & 1 \\
\hline врыколочик & 2 & дас & ссецо & $13 a$ & 11 & цечик & 13 & зыдр & ооня & 1 & лыжоц & & 1 & мимоляг & ко & 1 \\
\hline врыколочко & 2 & дас & ссечик & 1 за & n & цечка & 13 & зыдр & ооцо & 1 & лыжоч & ник & 1 & мимоляниє & & 1 \\
\hline врыколошко & 3 & дас & ссечко & $33 a$ & $\mathrm{pe}$ & цешко & 23 & зыдр & рочик & 1 & лыжоч & нки & 1 & мимолянис & ечик & 1 \\
\hline врыколучка & 1 . & дас & 0 & $13 a$ & & & 13 & зыдр & оОчко & 1 & лыжоч & нко & 2 & мимоляг & ечко & 2 \\
\hline врыколышко & 1 & дас & ссешка & $13 a$ & $\mathrm{p}$ & цонька & 13 & зыдр & рошка & 1 & лыжош & шко & 2 & мимолянис & шко & 2 \\
\hline врыкольце & 1 & дас & ссешко & 1 за & $T$ & цошко & 13 & зыдр & рошко & 6 & лыжош & & 1 & мимоляғ & еще & 1 \\
\hline врыкуля & 1 & дас & ссеюшке & $13 a$ & ip & a & 13 & зыдр & роще & 1 & лыжуш & шко & 1 & мимоляниі & & 1 \\
\hline выколочка & 1 & дас & ссушко & $13 a$ & ip & цушко & 13 & зыдр. & ру́шка & 1 & лыжцо & & 1 & мимолянчи & & 1 \\
\hline & & дас & ссчик & 1 за & ipe & ико & 1 & & & & лыжчи & & 1 & мимолянье & ечко & 2 \\
\hline & & & & & & Ычко & 1 & & & & & & 1 & МИМОЛЯНЬН & ОШко & 1 \\
\hline
\end{tabular}




\begin{tabular}{|c|c|c|c|c|c|c|c|c|c|c|c|c|}
\hline \multicolumn{2}{|l|}{ наке́сло } & \multicolumn{3}{|c|}{ ото́мя } & \multicolumn{4}{|c|}{ прикви́ждие } & \multicolumn{2}{|l|}{ рицо́ } & \multicolumn{2}{|l|}{ ули́бье } \\
\hline накёселко & 1 & \multicolumn{3}{|c|}{ отомице } & \multicolumn{4}{|c|}{ привкуждиеничко 1} & рицко & & 1 улибьедко & t \\
\hline накеслик & 1 & \multicolumn{2}{|c|}{ отомлятко } & 1 & \multicolumn{3}{|c|}{ приквуждиевко } & $1 \mathrm{p}$ & рицоко & & 1 улибьек & \\
\hline накеслицо & 1 & \multicolumn{2}{|c|}{ отомышко } & 1 & \multicolumn{3}{|c|}{ приквуждиец } & $1 \mathrm{p}$ & \multicolumn{2}{|c|}{ рицонечко } & 1 улибьёнки & \\
\hline накесличко & 2 & \multicolumn{2}{|c|}{ отомяня } & 1 & \multicolumn{3}{|c|}{ приквуждиеце } & \multicolumn{3}{|c|}{ рицоньечко } & 1 улибьеце & 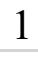 \\
\hline накеслок & 1 & \multicolumn{2}{|c|}{ отомяче } & 1 & \multicolumn{3}{|c|}{ приквуждиецо } & $1 \mathrm{p}$ & \multicolumn{2}{|l|}{ рицочик } & 1 улибьечик & \\
\hline накеслонечк & 1 & \multicolumn{2}{|c|}{ отомячик } & 1 & \multicolumn{3}{|c|}{ приквуждиечик } & $1 \mathrm{p}$ & \multicolumn{2}{|l|}{ рицочко } & 1 улибьечко & \\
\hline накеслонко & 1 & & омячко & 1 & I приквуждие & чко & & $1 \mathrm{p}$ & рицошка & & 1 улибьешка & 2 \\
\hline накеслоце & 1 & отC & омяшечка & 1 & приквуждин & БиІ & & $1 \mathrm{p}$ & рицошко & & 2 улибьешко & 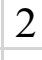 \\
\hline накеслочик & 1 & отс & омяшка & 1 & приквуждиу & ШК & & $1 \mathrm{p}$ & рицуля & & 1 улибьице & 1 \\
\hline накеслочко & 1 & отс & омяшко & 6 & 5 приквуждич & & & $2 \mathrm{p}$ & рицушка & & 1 улибьюшко & \\
\hline накеслошка & 1 & & & & приквуждию & Ошк & & $1 \mathrm{p}$ & рицушко & & 1 улибьятик & \\
\hline накеслошко & 1 & & & & приквуждок & & & $1 \mathrm{p}$ & рицышко & & 1 улыбьенечко & \\
\hline накеслушка & 1 & & & & приквуждье & Чко & & $1 \mathrm{r}$ & ричико & & 2 & \\
\hline накеслушко & 1 & & & & & & & & & & & \\
\hline хру́чин & & & язи́іро & & ялёко & & & & лекса́ма & & Ли́корь & \\
\hline хрунчинчик & & $1 s$ & язырко & & 3 ялёка & 1 & Аль & екса & аманька & 1 & Ликорек & 1 \\
\hline хручинко & & $2 s$ & язырко & & 1 ялёковка & 1 & Алс & екса & амачка & 2 & Ликорёк & 1 \\
\hline хручинко & & $1 s$ & языроцо & & 1 ялёковко & 1 & Алс & екса & амашка & 1 & Ликоречек & 1 \\
\hline хручинок & & $2 s$ & язырочик & & 1 ялёколько & 1 & Аль & екса & амик & 1 & Ликорик & 6 \\
\hline хручиноко & & $1 s$ & язырочко & & 3 ялёкочик & 1 & Алс & екса & амка & 1 & Ликорочка & 1 \\
\hline хручиночен & & $1 s$ & язырочкр & & 1 ялекочко & 1 & Алс & ексс & амочка & 2 & Ликорушка & 2 \\
\hline хручиночик & & $1 s$ & язырошко & & 1 ялёкочко & 2 & Алс & екса & амушка & 10 & Ликорчик & 1 \\
\hline хручиношка & & $1 s$ & языруня & & 1 ялекочо & 1 & Cas & муш & шка & 1 & Ликорька & 1 \\
\hline хручиношко & & $1 s$ & язырушка & & 1 ялекошко & 1 & & & & & Ликорьчик & 2 \\
\hline хручинушко & & $2 s$ & язырушко & & 3 ялекушка & 1 & & & & & Ликорьюшка & 1 \\
\hline хручинцо & & $2 s$ & язырышкс & & 1 ялекушко & 2 & & & & & Ликорюшка & 2 \\
\hline хручиньечкс & & 1 & & & ялекцо & 1 & & & & & & \\
\hline хручиньюш & & 1 & & & ялекша & 1 & & & & & & \\
\hline & & & & & ялекьечко & 1 & & & & & & \\
\hline & & & & & ялёчко & 1 & & & & & & \\
\hline Маря́са & & & Сереми́р & & Тифа́н & & & & & & & \\
\hline Марясачка & $1 \mathrm{~N}$ & Иирс & очек & 1 & Тафанчик & 1 & & & & & & \\
\hline Маряска & $2 C$ & epe & мирик & 5 & Тифаник & 3 & & & & & & \\
\hline Марясок & $1 \mathrm{C}$ & epe & мирушка & 6 & Тифанок & 1 & & & & & & \\
\hline Марясонька & $2 \mathrm{C}$ & eper & мирчик & 7 & Тифаночка & 1 & & & & & & \\
\hline Марясочка & $2 \mathrm{C}$ & eper & мирька & 1 & Тифанушка & 6 & & & & & & \\
\hline Марясоша & 1 & & & & Тифанчик & 7 & & & & & & \\
\hline Марясушка & 5 & & & & Тифанышко & 1 & & & & & & \\
\hline Маряська & 1 & & & & & & & & & & & \\
\hline Маряшечка & 1 & & & & & & & & & & & \\
\hline Маряшка & 1 & & & & & & & & & & & \\
\hline Мяряска & 1 & & & & & & & & & & & \\
\hline
\end{tabular}




\section{Orosz II}

\begin{tabular}{|c|c|c|c|c|c|c|c|c|c|}
\hline \multicolumn{2}{|l|}{ бруж } & \multicolumn{2}{|l|}{ дагари́н } & \multicolumn{2}{|l|}{ дрезёмлец } & \multicolumn{2}{|l|}{ зламу́г } & \multicolumn{2}{|l|}{ илотро́м } \\
\hline бружек & 1 & дагарёнок & 1 & дреземка & 1 & зламугашка & & илотрёмик & 1 \\
\hline бружечок & 1 & дагаринайчик & 1 & дреземлёнок & 1 & зламугик & 3 & илотромик & 4 \\
\hline бружик & 16 & дагаринёк & 1 & дрезёмленчик & 1 & зламугок & & илотромишка & 1 \\
\hline бружичек & 1 & дагаринёнок & 1 & дреземлецик & 2 & зламугочек & & илотромка & 1 \\
\hline бружишка & 1 & дагариник & 1 & дрезёмлецик & 5 & зламугочка & & илотромочка & 1 \\
\hline бружка & 2 & дагаринишко & 1 & дреземлецка & 1 & зламугошечек & & илотромпочка & 1 \\
\hline бружок & 6 & дагаринка & 3 & дрезёмлецок & 1 & зламугушка & & илотромушка & 1 \\
\hline бружонок & 1 & дагаринок & 2 & дреземлецульчик & 2 & зламугчик & & илотромчик & 21 \\
\hline бружочек & 2 & дагариночка & 1 & дрезёмлецчик & 1 & зламугчичка & 1 & илотромшенкок & 2 \\
\hline бружчик & 1 & дагаринушка & 4 & дреземлёчек & 1 & зламужек & 3 & илоьромка & 1 \\
\hline бружчок & 1 & дагаринчик & 16 & дрезёмлечек & 1 & зламужик & 6 & & \\
\hline & & дагаришечка & 1 & дреземлечик & 2 & зламужишка & 1 & & \\
\hline & & дагаришка & 1 & дрезёмлечик & 1 & зламужка & 2 & & \\
\hline & & & & дрезёмлечишка & 1 & зламужок & 3 & & \\
\hline & & & & дрёземлечишка & 1 & зламушек & 1 & & \\
\hline & & & & дреземлик & 1 & зломугонька & 1 & & \\
\hline & & & & дрезёмлик & 1 & & & & \\
\hline & & & & дрезёмличек & 1 & & & & \\
\hline & & & & дрезёмлушка & 1 & & & & \\
\hline & & & & дреземльчонок & 1 & & & & \\
\hline & & & & дрезёмлюшек & 1 & & & & \\
\hline & & & & дрезёмлюшка & 3 & & & & \\
\hline & & & & дреземнецек & 1 & & & & \\
\hline & & & & дрезёмчик & 1 & & & & \\
\hline
\end{tabular}




\begin{tabular}{|c|c|c|c|c|c|c|c|c|c|}
\hline \multicolumn{2}{|l|}{ кре́чник } & \multicolumn{2}{|l|}{ лорх } & \multicolumn{2}{|l|}{ мырано́к } & \multicolumn{2}{|l|}{ ня́кож } & \multicolumn{2}{|l|}{ пёнгарь } \\
\hline кренчичка & 1 & лорханчик & 1 & мыранёнок & 2 & накожечка & 1 & пёгрнарек & 1 \\
\hline кречинюшка & 1 & лорхец & 1 & мыранец & 1 & някожек & 4 & пенгарёк & 2 \\
\hline кречнёнок & 1 & лорхечек & 1 & мырано куйчик & 1 & някожец & 1 & пёнгарек & 1 \\
\hline кречникак & 1 & лорхик & 7 & мыранокочек & 1 & някожик & 12 & пёнгарёк & 4 \\
\hline кречникишка & 1 & лорхок & 3 & мыранокушек & 1 & някожка & 9 & пенгаренок & 1 \\
\hline кречникочек & 1 & лорхочек & 1 & мыранокушка & 1 & някожок & 1 & пенгарёшка & 1 \\
\hline кречникулешок & 2 & лорхочик & 1 & мыранокчик & 1 & някожонок & 1 & пенгарик & 4 \\
\hline кречникушек & 1 & лорхушка & 2 & мыранокчичик & 1 & някожуля & 1 & пёнгарик & 6 \\
\hline кречникушка & 1 & лорху́шка & 3 & мыраночек & 18 & някожуча & 2 & пёнгарик & 1 \\
\hline кречникчик & 1 & лорхушок & 2 & мыраночик & 1 & някожчик & 2 & пенгарок & 1 \\
\hline кречничек & 10 & лорхчик & 1 & мыраночка & 1 & & & пёнгарок & 1 \\
\hline кречничок & 6 & лорхчок & 1 & мыраношенька & 1 & & & пенгаронок & 2 \\
\hline кречничонок & 1 & лоршик & 5 & мыраношка & 1 & & & пёнгарочек & 1 \\
\hline кречнюля & 1 & лоршок & 1 & мыроношка & 1 & & & пёнгарушка & 1 \\
\hline кречнюшка & 1 & лоршуга & 1 & & & & & пёнгарчик & 3 \\
\hline кречочка & 1 & лорщик & 1 & & & & & пёнгарька & 1 \\
\hline \multirow[t]{3}{*}{ кречочник } & 1 & & & & & & & пёнгарьчик & 1 \\
\hline & & & & & & & & пеньгарчик & 1 \\
\hline & & & & & & & & пнгарёк & 1 \\
\hline
\end{tabular}




\begin{tabular}{|c|c|c|c|c|c|c|c|c|c|}
\hline \multicolumn{2}{|l|}{ то́готь } & \multicolumn{2}{|l|}{ черьмы́бь } & \multicolumn{2}{|l|}{ э́вребист } & \multicolumn{2}{|l|}{ влю́рба } & \multicolumn{2}{|l|}{ ви́ба } \\
\hline тоготя & 1 & чермыбчик & 1 & эврибисток & 1 & влюбруша & 1 & выбака & 1 \\
\hline тоготейка & 1 & чермыбешек & 1 & эвребистек & 1 & влюрбавушка & 2 & выбалинка & 2 \\
\hline тоготёк & 1 & чермыбьля & 2 & эвребистик & 15 & влюрбаха & 1 & выбанька & 1 \\
\hline тоготёнок & 1 & чермыбьчик & 1 & эвребистичек & 2 & влюрбачка & 3 & выбачка & 4 \\
\hline тоготенька & 1 & чермыбюшка & 1 & эвребисток & 3 & влюрбаша & 1 & выбашка & 1 \\
\hline тоготечек & 1 & черьмбырёк & 1 & эвребисточек & 1 & влюрбашенька & 1 & выбка & 10 \\
\hline тоготёчек & 1 & черьмыбек & 1 & эвребистушка & 4 & влюрбичка & 1 & выбонька & 3 \\
\hline тоготик & 2 & черьмыбёк & 2 & эвребристик & 1 & влюрбка & 1 & выбочка & 4 \\
\hline тоготок & 9 & черьмыбёнок & 1 & эвребчонок & 1 & влюрбовка & 1 & выбушка & 7 \\
\hline тоготолик & 1 & черьмыбенька & 1 & эврибистик & 4 & влюрбонька & 1 & выбька & 1 \\
\hline тоготочек & 3 & черьмыберек & 1 & & & влюрбочка & 10 & & \\
\hline тоготушек & 1 & черьмыбец & 1 & & & влюрбочка & 1 & & \\
\hline тоготчик & 2 & черьмыбик & 3 & & & влюрбуша & 1 & & \\
\hline тоготька & 2 & черьмыбичек & 1 & & & влюрбушка & 9 & & \\
\hline тоготьчик & 1 & черьмыбка & 2 & & & & & & \\
\hline тоготяра & 1 & черьмыбочка & 1 & & & & & & \\
\hline тогочаа & 1 & черьмыбрёнок & 1 & & & & & & \\
\hline тогочишка & 1 & черьмыбушек & 1 & & & & & & \\
\hline тогушка & 1 & черьмыбушка & 3 & & & & & & \\
\hline & & черьмыбчик & 3 & & & & & & \\
\hline & & черьмыбычка & 1 & & & & & & \\
\hline & & черьмыбьейка & 1 & & & & & & \\
\hline & & черьмыбьечек & 1 & & & & & & \\
\hline & & черьмыбьчик & 1 & & & & & & \\
\hline & & черьмычик & 1 & & & & & & \\
\hline
\end{tabular}




\begin{tabular}{|c|c|c|c|c|c|c|c|c|c|}
\hline \multicolumn{2}{|l|}{ ехлю́нна } & ки́чица & & \multicolumn{2}{|l|}{ муня́чь } & \multicolumn{2}{|l|}{ обы́рня } & \multicolumn{2}{|l|}{ раскля́тка } \\
\hline ехлюнка & & 3 киченька & & унячевка & & 1 обыреночка & & 1 расклятинка & 1 \\
\hline ехлюнка & 2 & 2 кичечка & $1 \mathrm{M}$ & уняченька & & 4 обырка & & 1 расклятишка & 1 \\
\hline ехлюннаночка & 1 & кичинька & & унячечка & & 1 обырневка & & 1 раскляткаечка & 2 \\
\hline ехлюнначка & 2 & 2 кичитушка & $1 \mathrm{M}$ & унячик & & 1 обырнец & & 1 раскляточка & 17 \\
\hline ехлюнненька & 1 & 1 кичицавочка & $1 \mathrm{M}$ & унячичка & & 2 обырнечка & & 2 расклятуха & 2 \\
\hline ехлюннечка & 1 & 1 кичицайка & $1 \mathrm{M}$ & унячка & 1 & 6 обырнёшка & & 1 расклятушка & 7 \\
\hline ехлюнничка & 1 & кичицака & $1 \mathrm{M}$ & унячонка & & 1 обырничка & & 2 раскляту́шка & 2 \\
\hline ехлюннка & & 4 кичицацичка 1 & & унячуля & & 1 обырнушка & & 3 расклятченька & 1 \\
\hline ехлюннонка & & 2 кичицачка & $1 \mathrm{M}$ & унячушка & & 1 обырну́шка & & 2 & \\
\hline ехлюнночка & 10 & ) кичицка & $5 \mathrm{M}$ & унячьенька & & 1 обырнянка & & 1 & \\
\hline ехлюннушка & 5 & 5 кичицонька & $1 \mathrm{M}$ & унячька & & 2 обырняночкс & & 1 & \\
\hline ехлюнняра & & 1 кичицулька & $2 \mathrm{M}$ & унячьмунюшка & & 2 обырняхуля & & 2 & \\
\hline ехлюншка & & 1 кичицушка & $2 \mathrm{M}$ & уняшка & & 1 обырняченьк & & 1 & \\
\hline ехлюнька & & 1 кичицу́шка & 1 & & & обырнячка & & 1 & \\
\hline \multirow[t]{5}{*}{ эхлюннчка } & & 1 кичичечка & 1 & & & обырняша & & 2 & \\
\hline & & кичичка & 9 & & & обырняшень & & 1 & \\
\hline & & кичишка & 2 & & & обырняшка & & 4 & \\
\hline & & кичницевочка 1 & 1 & & & обырушка & & 2 & \\
\hline & & кичушка & 1 & & & & & & \\
\hline \multicolumn{2}{|l|}{ хиси́я } & \multicolumn{2}{|l|}{ бы́лыздо } & \multicolumn{2}{|l|}{ заре́пце } & \multicolumn{2}{|l|}{ лыжо́ } & \multicolumn{2}{|l|}{ наке́сло } \\
\hline хисиёнка & 1 & былыздонушко & 1 & зарепечко & 3 & лыжеце & 1 & накеселко & 1 \\
\hline хисиечка & 3 & былыздёнко & 1 & зарепушко & 4 & лыжечко & 3 & накеслёк & 1 \\
\hline хисийка & 5 & былыздёнок & 1 & зарепценка & 2 & лыжешко & 1 & накеслец & 1 \\
\hline хисинька & 2 & былыздецо & 1 & зарепценька & 1 & лыжишко & 2 & накеслецо & 1 \\
\hline хисиошечка & 1 & былыздик & 1 & зарепцечко & 4 & лыжко & 1 & накеслечко & 1 \\
\hline хисичка & 1 & былыздко & 3 & зарепцешко & 2 & лыжок & 2 & накеслице & 10 \\
\hline хисишка & 1 & былыздок & 1 & зарепцещко & 1 & лыжомка & 2 & накесловка & 2 \\
\hline хисиюля & 1 & былыздомка & 2 & зарепцик & 1 & лыжонок & 1 & накесловочко & 1 \\
\hline хисиюшка & 10 & былыздонок & 1 & зарепцишко & 1 & лыжонько & 2 & накеслонко & 1 \\
\hline хисиямочка & 1 & былыздонюшко & 1 & зарепцо & 1 & лыжонюшко & 1 & накеслонюшко & 1 \\
\hline хисиянная & 2 & былыздотько & 1 & зарепцушко & 3 & лыжотько & 1 & накеслочик & 1 \\
\hline хисиянушка & 1 & былыздочка & 2 & зарепчечко & 1 & лыжочка & 1 & накеслочка & 2 \\
\hline хисиянька & 1 & былыздочко & 3 & зарепчико & 1 & лыжочко & 4 & накеслочко & 3 \\
\hline хисиячка & 2 & былыздочье & 1 & зарепчичко & 1 & лыжочушко & 1 & накеслошко & 2 \\
\hline хисияша & 1 & былыздошка & 2 & зарепчишко & 1 & лыжошка & 1 & накеслушко & 2 \\
\hline \multirow[t]{5}{*}{ хиська } & 1 & былыздошко & 5 & зарепчонок & 2 & лыжошко & 3 & накеслюшко & 1 \\
\hline & & былыздушко & 4 & зерепцешке & 1 & лыжушко & 1 & & \\
\hline & & былыздынько & 1 & зрепцешко & 1 & лыжце & 2 & & \\
\hline & & былыздышко & 1 & & & лыжцо & 1 & & \\
\hline & & & & & & лыжчонок & 1 & & \\
\hline
\end{tabular}




\begin{tabular}{|c|c|c|c|c|c|c|c|c|c|}
\hline \multicolumn{2}{|l|}{ рицо́ } & \multicolumn{2}{|l|}{ язы́ро } & \multicolumn{2}{|l|}{ Алекса́ма } & \multicolumn{2}{|l|}{ Ли́корь } & \multicolumn{2}{|l|}{ Сереми́р } \\
\hline рицовочко & 1 & язырка & 1 & Алексамачка & 2 & Ликорек & 3 & Семирушка & 1 \\
\hline рицоленька & 1 & язырко & 3 & Алексамашка & 2 & Ликорёк & 10 & Серемирушко & 1 \\
\hline рицонишко & 1 & язырнушко & 1 & Алексаменька & 1 & Ликорёнок & 1 & Серемирка & 8 \\
\hline рицонок & 1 & язырок & 2 & Алексамка & 5 & Ликоренька & 1 & Серемирушка & 7 \\
\hline рицонько & 2 & языронка & 2 & Алексамочка & 4 & Ликорёша & 1 & Серемирушко & 1 \\
\hline рицочка & 1 & языронька & 1 & Алексамушка & 18 & Ликорик & 2 & Серемирчик & 14 \\
\hline рицочко & 3 & языронько & 2 & & & Ликорка & 1 & & \\
\hline рицошка & 1 & языротько & 1 & & & Ликорушка & 3 & & \\
\hline рицошко & 5 & язырочка & 1 & & & Ликорчик & 1 & & \\
\hline рицушко & 3 & язырочко & 5 & & & Ликорька & 5 & & \\
\hline ричико & 10 & язырушко & 5 & & & Ликорьмушко & 1 & & \\
\hline рыцко & 1 & язырце & 4 & & & Ликорьчик & 1 & & \\
\hline рыцонько & 1 & язырцо & 1 & & & Ликорючик & 1 & & \\
\hline & & язырчик & 1 & & & Ликорюшка & 1 & & \\
\hline & & & & & & Ликорюшко & 1 & & \\
\hline
\end{tabular}

\section{Orosz III}

\begin{tabular}{|c|c|c|c|c|c|c|c|c|c|}
\hline \multicolumn{2}{|l|}{ ба́па } & \multicolumn{2}{|l|}{ врощ } & \multicolumn{2}{|l|}{ допо́зм } & \multicolumn{2}{|l|}{ евдо́пус } & \multicolumn{2}{|l|}{ злюбоду́н } \\
\hline бапанька & 1 & врощёнок & 1 & допозменька & 1 & евдопусец & 1 & злобдунчик & 1 \\
\hline бапачик & 2 & врощец & 2 & допозмец & 1 & евдопусечка & 1 & злободишко & 1 \\
\hline бапачка & 2 & врощик & 19 & допозмик & 17 & евдопусик & 19 & злободунишка & 1 \\
\hline бапец & 1 & врошица & 1 & допозминчик & 1 & евдопусичек & 1 & злободунчик & 1 \\
\hline бапик & 3 & врощичек & 1 & допозмичек & 1 & евдопусишек & 1 & злюбодунец & 1 \\
\hline бапка & 1 & врощичишка & 1 & допозмишка & 3 & евдопусишка & 1 & злюбодунишка & 3 \\
\hline бапок & 3 & врощка & 1 & допозмок & 1 & евдопуска & 2 & злюбодунка & 2 \\
\hline бапочек & 1 & врощок & 2 & допозмочник & 1 & евдопусок & 1 & злюбодунок & 1 \\
\hline бапочка & 12 & врощчик & 1 & допозмучек & 1 & евдопусочек & 1 & злюбодунушка & 1 \\
\hline бапунчик & 1 & & & допозмушек & 1 & евдопусушка & 1 & злюбодунчик & 15 \\
\hline бапуня & 1 & & & допозмюшка & 1 & евдопуська & 1 & злюбодюнчик & 1 \\
\hline бапушка & 3 & & & допомозмик & 1 & евдопушка & 1 & злюбунчик & 1 \\
\hline
\end{tabular}




\begin{tabular}{|c|c|c|c|c|c|c|c|c|c|}
\hline \multicolumn{2}{|l|}{ кирдь } & \multicolumn{2}{|l|}{ ктреф } & \multicolumn{2}{|l|}{ млёнь } & \multicolumn{2}{|l|}{ нюлп } & \multicolumn{2}{|l|}{ отрыка́зд } \\
\hline кирдёныш & & 1 ктрефёнок & 1 & мленек & $1 \mathrm{H}$ & нюлпёнок & $1 \mathrm{o}$ & ортыказдничик & 1 \\
\hline кирдец & & 1 ктрефик & 16 & млёненька & $1 \mathrm{H}$ & нюлпик & 180 & открызадушка & 1 \\
\hline кирдечка & & 1 ктрефишка & 1 & млёнец & $1 \mathrm{H}$ & нюлпичка & 10 & отрыказдак & 1 \\
\hline кирдик & & 8 ктрефка & 1 & мленечка & $1 \mathrm{H}$ & нюлпишка & 30 & отрыказдёнок & 1 \\
\hline кирдичек & & 2 ктрефкин & 1 & млёник & $2 \mathrm{H}$ & нюлпка & $1 \mathrm{o}$ & отрыказдик & 18 \\
\hline кирдишка & & 3 ктрефко & 1 & млёнишка & $1 \mathrm{H}$ & нюлпок & $1 \mathrm{o}$ & отрыказдишка & 1 \\
\hline кирдочка & & 1 ктрефок & 2 & мленчик & $1 \mathrm{H}$ & нюлпочек & 20 & отрыказдочек & 1 \\
\hline кирдьечок & & 1 ктрефочек & 2 & млёнчик & $5 \mathrm{H}$ & нюлпушка & 10 & отрыказдушек & 1 \\
\hline кирдька & & 4 ктрефочка & 2 & мленчик & $2 \mathrm{H}$ & нюлпчик & $1 \mathrm{o}$ & отрыказдушка & 2 \\
\hline кирдьюша & & 1 ктрефуша & 1 & млёнька & $4 \mathrm{r}$ & нюльпишка 1 & $1 \mathrm{o}$ & отрыказдюшечка & 1 \\
\hline кирдюжка & & 1 ктрефушка & 2 & млёньок & 1 & & & & \\
\hline кирдюшечк & & 1 & & мленьчик & 3 & & & & \\
\hline кирдюшка & & 2 & & млёньчик & 3 & & & & \\
\hline кирдюшок & & 1 & & млёньшик & 1 & & & & \\
\hline кирдяк & & 1 & & мленюшка & 1 & & & & \\
\hline кирдячок & & 2 & & млёня & 1 & & & & \\
\hline \multicolumn{2}{|l|}{ сиц } & \multicolumn{2}{|l|}{ у́стрей } & \multicolumn{2}{|l|}{ шливь } & \multicolumn{2}{|l|}{ ю́скреб } & \multicolumn{2}{|l|}{ вреньба́ } \\
\hline сицечек & 1 & устрейка & 8 & шливек & 1 & юскребек & & 1 вренбачка & 1 \\
\hline сицик & 13 & устрейок & 1 & шливёк & 1 & юскребёныш & & 1 вренбушка & 1 \\
\hline сицка & 3 & устрейчек & 1 & шливенька & 1 & юскребенька & & 1 вреньбанька & 1 \\
\hline сицок & 4 & устрейчик & 14 & шливец & 1 & юскребик & & 6 вреньбанюшка & 1 \\
\hline сицочек & 1 & устречик & 1 & шливик & 3 & юскребишко & & 1 вреньбачка & 3 \\
\hline сицулька & 1 & устреюшка & 1 & шливка & 2 & юскребок & & 8 вреньбашенька & 1 \\
\hline сицуля & 1 & устришко & 1 & шливник & 1 & юскребочек & & 1 вреньбашечка & 1 \\
\hline сицушка & 2 & устрюшка & 1 & шливок & 2 & юскребушка & & 1 вреньбашка & 2 \\
\hline сицышек & 1 & учтрейчик & 1 & шливушка & 2 & юскребчик & & 8 вреньбина & 1 \\
\hline \multirow[t]{8}{*}{ сичик } & 1 & & & шливчик & 7 & & & вреньбиха & 1 \\
\hline & & & & шливьек & 1 & & & вреньбица & 1 \\
\hline & & & & шливьеще & 1 & & & вреньбочка & 4 \\
\hline & & & & шливька & 3 & & & вреньбуша & 3 \\
\hline & & & & шливьчик & 3 & & & вреньбушечка & 1 \\
\hline & & & & шливьюшка & 1 & & & вреньбушка & 6 \\
\hline & & & & & & & & вреньбу́шка & 1 \\
\hline & & & & & & & & вреньюшка & 1 \\
\hline
\end{tabular}




\begin{tabular}{|c|c|c|c|c|c|c|c|c|c|c|c|c|c|}
\hline \multicolumn{2}{|l|}{ ди́фушка } & \multicolumn{4}{|c|}{ жёлостушка } & \multicolumn{4}{|c|}{ ме́шща } & \multicolumn{4}{|c|}{ объя́рдость } \\
\hline дивушечка & & \multicolumn{3}{|c|}{ желострушканёк } & 1 & \multicolumn{3}{|c|}{ мешечка } & 10 & \multicolumn{3}{|c|}{ объярдишко } & 1 \\
\hline дифулюшка & & \multicolumn{3}{|l|}{ желостуля } & 1 & \multicolumn{3}{|c|}{ мешщалка } & 1 o & \multicolumn{3}{|c|}{ объярдостёнушка } & 1 \\
\hline дифушенка & & \multicolumn{3}{|c|}{ желостушенька } & 2 & \multicolumn{3}{|c|}{ мешщаночка } & 2 o & \multicolumn{3}{|c|}{ объярдостенька } & 5 \\
\hline дифушенька & & \multicolumn{3}{|c|}{ жёлостушенька } & 2 & \multicolumn{3}{|c|}{ мешщанька } & \multicolumn{4}{|c|}{ объярдостинка } & 1 \\
\hline дифушечка & 1 & \multicolumn{3}{|c|}{ желостушечка } & 12 & \multicolumn{3}{|c|}{ мешщаня } & 1 o & \multicolumn{3}{|c|}{ объярдостка } & 1 \\
\hline дифушка & & \multicolumn{3}{|c|}{ жёлостушечка } & 5 & \multicolumn{3}{|c|}{ мешщаца } & 1 o & \multicolumn{3}{|c|}{ объярдосточка } & 1 \\
\hline дифушканька & & \multicolumn{3}{|c|}{ жёлостушка } & 2 & мешща & ЧК & & 3 o & объя & рдс & сстушка & 2 \\
\hline дифушкачка & & 2 жёлостушк & аньк & & 1 & мешща & ш & енька & 1 o & объя & рдс & рсту́шка & 1 \\
\hline дифушкашечк: & & 1 жёлостушку & ушк: & & 1 & мешща & ш & ечка & 1 o & объя] & рдс & остчка & 1 \\
\hline дифушунька & & 1 & & & & мешща & ш & & 1 o & рбъя1 & рдс & остька & 1 \\
\hline & & & & & & мешще & $\mathbf{H}^{7}$ & ка & 10 & рбъя1 & рдс & очка & 1 \\
\hline & & & & & & мешще & $\mathrm{HI}$ & ка & 10 & рбъя1 & рду & ушка & 3 \\
\hline & & & & & & мешще & $4 \mathrm{H}$ & & 10 & рбъя] & рді & ошка & 1 \\
\hline & & & & & & мешщи & & & 10 & рбъя1 & poc & гточка & 1 \\
\hline & & & & & & мешщи & Ца & & 10 & рбьян & рдс & стишка & 1 \\
\hline & & & & & & мешщи & {$[\mathbf{4}$} & & 1 o & обьяр & рду & шка & 1 \\
\hline & & & & & & мешщо & 41 & & 1 o & бояр & дос & етюшка & 1 \\
\hline & & & & & & мешщу & $\mathrm{HI}$ & ка & 1 & & & & \\
\hline & & & & & & мешщу & Ш & енька & 1 & & & & \\
\hline & & & & & & мешщу & ш & & 3 & & & & \\
\hline & & & & & & мешщý & Ш & & 1 & & & & \\
\hline & & & & & & мешчи & 41 & & 2 & & & & \\
\hline прозро́нья & & укры́ста & & & бар & ра́тице & & & вальт & & & зыдро́ & \\
\hline прозоньечка & 1 & укрыстанка & 1 & бар & оатиг & цее & 1 & вальи & шко & & 1 & зыдерко & 1 \\
\hline прозорнюшка & 1 & укрыстанушка & 1 & бар & оатиг & Іценко & 1 & вальте & ецо & & 1 & зыдёрко & 1 \\
\hline прозроночка & 1 & укрыстаня & 1 & бар & оатиг & ценько & 1 & вальте & ечко & & 1 & зыдерочко & 1 \\
\hline прозронушка & 1 & укрыстачка & 1 & бар & ратиг & цетко & 1 & вальті & ишеч & чко & 1 & зыдренько & 1 \\
\hline прозроньенька & 1 & укрысташка & 1 & бар & ратиг & іцечко & 2 & вальті & ишко & & 10 & зыдришко & 2 \\
\hline прозроньица & 2 & укрыстка & 1 & бар & оатиг & Іцешко & 4 & вальтс & оньец & це & 1 & зыдровьюшко & 1 \\
\hline прозроньичка & 1 & /крыстонька & 1 & бар & оатиг & Іцко & 3 & вальтс & оцо & & 1 & зыдрожка & 1 \\
\hline прозронька & 5 & крысточка & 15 & бар & оатиг & ццочка & 1 & вальтс & ошечl & нка & 1 & зыдронушко & 1 \\
\hline прозроньюшка & 10 & крыстушка & 4 & бар & оатиг & цу́шка & 1 & вальтс & ошечl & нко & 1 & зыдроцо & 1 \\
\hline прозроньялка & 1 & /крышстушка & 1 & бар & оатиг & цу́шко & 1 & вальтс & ошка & & 2 & зыдрочка & 1 \\
\hline прозроньячка & 2 & & & бар & атич & Ічко & 2 & вальтс & ошко & & 2 & зыдрочко & 2 \\
\hline прозроньяша & 1 & & & бар & оатиг & шшко & 5 & вальту & унуш & шко & 1 & зыдрошка & 4 \\
\hline прозронюшка & 1 & & & бар & оаткс & & 1 & вальту & ушко & & 2 & зыдрошко & 5 \\
\hline & & & & бар & ратю & ошечко & 1 & вальть & ышко & & 1 & зыдрушко & 1 \\
\hline & & & & & & & & & & & & зыдрышко & 2 \\
\hline
\end{tabular}


Initium 1 (2019)

\begin{tabular}{|c|c|c|c|c|c|}
\hline \multicolumn{2}{|l|}{ мимоля́ние } & \multicolumn{2}{|l|}{ ото́мя } & \multicolumn{2}{|l|}{ ули́бье } \\
\hline мимолянечко & 1 & 1 отомечко & 2 & улибушко & 2 \\
\hline мимоляниетко & & 1 отомичко & 2 & улибышко & 1 \\
\hline мимоляниечко & & 2 отомушко & 1 & улибьеце & 4 \\
\hline мимоляниешко & & 1 отомычко & 1 & улибьецо & 1 \\
\hline мимолянице & & 1 отомышко & 1 & улибьечко & 3 \\
\hline мимолянишко & & 1 отомьице & 1 & улибьешенькс & \begin{tabular}{l|l}
$\mathrm{O}$ & 1
\end{tabular} \\
\hline мимолянушко & & 2 отомька & 1 & улибьешечко & 1 \\
\hline мимолянце & & 1 отомьце & 1 & улибьешко & 5 \\
\hline мимоляньеце & & 4 отомяка & 1 & улибьице & 2 \\
\hline мимоляньешка & & 1 отомяко & 1 & у улибьишко & 1 \\
\hline мимоляньице & & 5 отомялько & 1 & улибьюшка & 1 \\
\hline мимоляньишко & & 1 отомянушко & 1 & улибьюшко & 2 \\
\hline мимоляньшко & & 1 отомячик & 1 & & \\
\hline мимоляньюшка & & 1 отомячко & 3 & & \\
\hline мимолянюшко & & 1 отомяшенька & 1 & & \\
\hline \multirow[t]{2}{*}{ мимоляшка } & & 1 отомяшка & 1 & & \\
\hline & & отомяшко & 4 & & \\
\hline \multicolumn{2}{|l|}{ ялёко } & \multicolumn{2}{|l|}{ Маря́са } & \multicolumn{2}{|l|}{ Тифа́н } \\
\hline ялёкечко & 1 & Марьясочка & 1 & Тифаничек & 1 \\
\hline ялеконце & 1 & Марясанька & 1 & Тифанка & 1 \\
\hline ялёконюшко & 1 & Марясаня & 1 & Тифанок & 1 \\
\hline ялёкотко & 1 & Марясашка & 1 & Тифанушка & 10 \\
\hline ялекочко & 2 & Марясенька & 1 & Тифанчик & 10 \\
\hline ялёкочко & 3 & Марясечка & 2 & Тифонушка & 1 \\
\hline ялёкушка & 1 & Марясик & 1 & Тифушка & 1 \\
\hline ялекушко & 1 & Марясишка & 1 & Фаня & 1 \\
\hline ялёкушко & 6 & Маряска & 2 & & \\
\hline ялёкцо & 1 & Марясонька & 2 & & \\
\hline ялёченько & 1 & Марясочка & 3 & & \\
\hline ялечко & 3 & Марясушка & 6 & & \\
\hline ялёчко & 4 & Маряська & 3 & & \\
\hline
\end{tabular}




\section{Német}

\begin{tabular}{|c|c|c|c|c|c|c|c|c|c|}
\hline \multicolumn{2}{|l|}{ Abbräper } & \multicolumn{2}{|l|}{ Abwäklen } & \multicolumn{2}{|c|}{ Aufkraumangen } & \multicolumn{2}{|c|}{ Ausgügen } & \multicolumn{2}{|l|}{ Bäkl } \\
\hline Abbräperchen 3 & \multicolumn{2}{|r|}{ Abwäcklenchen } & \multicolumn{3}{|c|}{ Aufkraumangchen } & \multicolumn{2}{|c|}{ Ausgügchen } & 16 Bäcklchen & 1 \\
\hline Abbraperlein & \multicolumn{2}{|r|}{ Abwäkchen } & 1 & \multicolumn{2}{|c|}{ Aufkraumängchen } & \multicolumn{2}{|c|}{ Ausgügelein } & 4 Bäkelchen & 2 \\
\hline Abbräperlein 1 & \multicolumn{2}{|r|}{ Abwäkelchen } & 71 & \multicolumn{2}{|c|}{ Aufkraumangelchen } & \multicolumn{2}{|c|}{ Ausgügenchen } & 19 Bäkelein & 3 \\
\hline chen & \multicolumn{2}{|r|}{ Abwäkelein } & & \multicolumn{2}{|c|}{ Aufkraumängelchen } & \multicolumn{2}{|c|}{ Ausgügenlein } & 15 Bäklchen & 24 \\
\hline \multirow[t]{8}{*}{ lein } & \multicolumn{2}{|r|}{ Abwäkelnchen } & 1 & \multicolumn{2}{|c|}{ Aufkraumängelein } & \multicolumn{2}{|c|}{ Ausgüglein } & 5 Bäklein & 29 \\
\hline & \multicolumn{2}{|r|}{ Abwäklchen } & 3 & \multicolumn{2}{|c|}{ Aufkraumangenchen } & \multicolumn{2}{|l|}{ chen } & 12 Bäkllein & 1 \\
\hline & \multicolumn{2}{|r|}{ Abwäklechen } & 2 & \multicolumn{2}{|c|}{ Aufkraumangenlein } & 9 lein & & 6 chen & 10 \\
\hline & & Abwäklein & $12 A$ & Aufkraumangerlei & & 1 & & lein & 6 \\
\hline & & Abwäklenchen 2 & $27 A$ & Aufkraumanglein & & 4 & & & \\
\hline & & Abwäklenlein & $3 A$ & Aufkraumänglein & & 3 & & & \\
\hline & & chen & & chen & & 9 & & & \\
\hline & & lein & & lein & & 9 & & & \\
\hline Betlelch & & Bicken & & Böngel & & Borwul & & Bruhel & \\
\hline Betlechlein & & 3 Bickchen & 7 & Bögelein & 1 & Borwulchen & 47 & Bruhelchen 4 & 40 \\
\hline Betleichlein & & 1 Bickenchen & 25 & Böngelchen 2 & 46 & Borwulein & 5 & Bruhelein & 11 \\
\hline Betlelchchen & & 6 Bickenlein & 12 & Böngelein & 9 & Borwullein & 1 & Bruhellein & 2 \\
\hline Betlelchelchen & & 1 Bicklein & 14 & Böngellein & $1]$ & Borwülchen & 4 & Bruhlchen & 1 \\
\hline Betlelchelein & & 1 chen & 12 & Bönglein & 1 & chen & 14 & Bruhlein & 2 \\
\hline Betlelchen & & 20 lein & 5 & chen & 15 & lein & 4 & Brühelchen & 1 \\
\hline Betlelchlein & & 27 & & lein & 2 & & & chen & 15 \\
\hline chen & & 2 & & & & & & lein & 2 \\
\hline elein & & 1 & & & & & & & \\
\hline lein & & 14 & & & & & & & \\
\hline Charochen & & Daschlöge & & Dischenge & & Entliepen & & Ertraßang & \\
\hline Charochchen & & chen & 3 & chen & 2 & chen & 15 & chen & 11 \\
\hline Charochelein & & Daschlögchen & 10 & Dischengchen & 16 & Entliepchen & 18 & Ertraßangchen & 29 \\
\hline Charochen & & Daschlögechen & 9 & Dischengechen & 4 & Entliepelein & 1. & Ertraßängchen & 5 \\
\hline Charochenchen & 12 & Daschlögelchen & 4 & Dischengelchen & 1 & Entliepenchen & 29 & Ertraßangelein & 4 \\
\hline Charochenlein & 24 & Daschlögelein & 27 & Dischengelein & 34 & Entliepenlein & 3 & Ertraßanglein & 18 \\
\hline Charochlein & 11 & Daschlöglein & 5 & Dischenglein & 2 & Entlieplein & 3 & lein & 4 \\
\hline Charonchenlein & & lein & 14 & lein & 14 & lein & 1 & & \\
\hline Charöchelchen & 1 & & & & & & & & \\
\hline Charöchlein & 2 & & & & & & & & \\
\hline chen & 5 & & & & & & & & \\
\hline lein & 12 & & & & & & & & \\
\hline
\end{tabular}




\begin{tabular}{|c|c|c|c|c|c|c|c|c|c|c|c|c|}
\hline Füskle & \multicolumn{4}{|c|}{ Gedäsche } & \multicolumn{4}{|c|}{ Hafieger } & \multicolumn{2}{|l|}{ Hitschel } & \multicolumn{2}{|l|}{ Hutrusch } \\
\hline chen & \multicolumn{4}{|c|}{12 chen } & \multicolumn{3}{|c|}{2 chen } & $11 \mathrm{c}$ & chen & 12 & chen & 6 \\
\hline Flüsklechen & \multicolumn{4}{|c|}{ Gedäschchen } & \multicolumn{3}{|c|}{ Hafiegchen } & 11 & lein & 211 & Hutruschchen & 27 \\
\hline Füskelchen & \multicolumn{4}{|c|}{ Gedäschechen } & \multicolumn{3}{|c|}{ Hafiegerchen } & $35 \mathrm{H}$ & Hitcchelchen & 11 & Hutruschelein & 1 \\
\hline Füsklchen & \multicolumn{4}{|c|}{ Gedäschelchen } & \multicolumn{3}{|c|}{ Häfiegerchen } & $1 \mathrm{H}$ & Hitschelchen & 401 & Hutruschen & 1 \\
\hline Füsklechen 2 & \multicolumn{4}{|c|}{ Gedäschelein } & \multicolumn{3}{|c|}{ Hafiegerlein } & $15 \mathrm{H}$ & Hitschelein & 91 & Hutruschlein & 20 \\
\hline Füsklein & \multicolumn{4}{|c|}{ Gedäschlein } & \multicolumn{3}{|c|}{ Hafieglein } & $1 \mathrm{H}$ & Hitschellein & 31 & Hutrüschchen & 3 \\
\hline Füsklelein & \multicolumn{3}{|c|}{ lein } & 1 & $4 \mathrm{Haf}$ & fieherc & chen & $1 \mathrm{H}$ & Hitschlein & 11 & Hutrüschlein & 2 \\
\hline Füskllein & 1 & & & & Haf & fiergerl & lein & 1 & & & lein & 9 \\
\hline lein & 4 & & & & lein & & & 5 & & & & \\
\hline Jameiz & & Kiggel & & & ockel & & Mar & rögel & Mürg & & kürl & \\
\hline chen & 9 cher & & $13 \mathrm{cl}$ & len & & 14 che & & & 13 chen & & 3 chen & 14 \\
\hline Jameinzchen 1 & Kig & ggelchen & 41 le & & & 2 leir & & & 3 lein & & 2 lein & 1 \\
\hline Jameizchen 34 & 4 Kig & ggelein & $8 \mathrm{~L}$ & cke & Ichen & $39 \mathrm{Ma}$ & arogel & lchen & n 1 Mürgchen & & 6 Opfanku & 1 \\
\hline Jameizelein & 1 Kigs & ggellein & & & lein & 10 Mä & ärogel & lchen & n 1 Mürgeche & & $1 \mathrm{Op}$ & 43 \\
\hline Jameizlein & 9 Kig & gglein & & & llein & $1 \mathrm{Ma}$ & arögel & lchen & n 40 Mürgelein & n 41 & 1 Opfankü & 6 \\
\hline lein & 7 lein & & & icke & Ichen & $1 \mathrm{Ma}$ & arögel & lein & 6 Mürglein & & 4 Opfanl & 2 \\
\hline & & & & $\ddot{j}$ & lein & $1 \mathrm{Ma}$ & arögel & llein & 1 & & & \\
\hline & & & & & & $1 \mathrm{Ma}$ & arögle & & 2 & & & \\
\hline Pange & & Pla & autsc & & & Plü & issel & & Pröffel & & $\mathrm{Pu}$ & \\
\hline lein & $16 \mathrm{cl}$ & chen & & & $10 \mathrm{cl}$ & then & & 15 & 5 chen & 13 & 3 chen & 14 \\
\hline Pängchen & $21 \mathrm{e}$ & lein & & & $61 \mathrm{e}$ & ein & & 1 & 1 lein & 21 & 1 lein & 1 \\
\hline Pangechen & $4 \mathrm{P}$ & Plauts & chen & & $30 \mathrm{P}$ & Plüssel & Ichen & 40 & Pröffelchen & 42 & 2 Puche & 33 \\
\hline Pangelchen & $1 \mathrm{P}$ & Pläutsch & chen & & $6 \mathrm{P}$ & Plüssel & lein & 3 & 3 Pröffelein & & 5 Puchelein & 9 \\
\hline Pangelein & $40 \mathrm{P}$ & Plautsch & nelch & & $1 \mathrm{P}$ & Plüssell & llein & 4 & 4 Pröffellein & & 2 Puchellein & 1 \\
\hline Pängelein & $1 \mathrm{P}$ & Plautsch & neleir & & $2 \mathrm{P}$ & Plüssle & in & 1 & Pröfflein & & 1 Puchlein & 2 \\
\hline Panglein & $2 \mathrm{P}$ & Plautsch & en & & $1 \mathrm{P}$ & Prüssel & lein & 2 & 2 & & Püchelchen & 4 \\
\hline Pänglein & $1 \mathrm{P}$ & Plautsc & lein & & 12 & & & & & & Püchlein & 1 \\
\hline Ratzeche & & & pple & & & Sausel & & & Schbaketzen & & Schkettal & \\
\hline lein & 15 & chen & & 11 & chen & & $13 \mathrm{c}$ & chen & & 10 & chen & 10 \\
\hline Ratzchen & 1 & lein & & 5 & lein & & 31 & lein & & 51 & lein & 5 \\
\hline Ratzechelchen & 1 & Röpelc & then & 3 & Sause & elchen & $40 s$ & Schat & bketzenlein & 1 & Schkettalchen & 26 \\
\hline Ratzechelein & 38 & Röpele & & 1 & Säuse & elchen & $4 S$ & Schb & aketzchen & 12 & Schkettälchen & 2 \\
\hline Ratzechen & 3 & Röplch & & 4 & Sause & elein & $8 \mathrm{~s}$ & Schb & aketzelchen & 1 & Schkettalein & 13 \\
\hline Ratzechlein & 7 & Röplec & then & 24 & & & & Schb & aketzelein & 2 & Schkettallein & 8 \\
\hline & & Röplei & & 10 & & & & Schb & aketzenchen & 25 & Schkettchen & 1 \\
\hline & & Röplel & ein & 10 & & & & Schb & aketzenlein & 7 & & \\
\hline & & & & & & & & Schb & aketzlein & 3 & & \\
\hline
\end{tabular}




\begin{tabular}{|c|c|c|c|c|c|c|c|c|c|c|c|c|c|c|c|c|c|}
\hline \multicolumn{2}{|l|}{ Speurl } & \multicolumn{5}{|c|}{ Spiecheinger } & \multicolumn{4}{|c|}{ Stragel } & \multicolumn{4}{|c|}{ Sutterei } & \multicolumn{3}{|c|}{ Tengel } \\
\hline chen & \multicolumn{5}{|c|}{13 chen } & $6 \mathrm{c}$ & \multicolumn{3}{|c|}{ chen } & \multicolumn{4}{|c|}{14 chen } & 7 & \multicolumn{2}{|c|}{ chen } & 12 \\
\hline lein & \multicolumn{5}{|c|}{2 lein } & 91 & \multicolumn{3}{|c|}{ lein } & \multicolumn{4}{|c|}{1 lein } & & \multicolumn{2}{|c|}{ lein } & 3 \\
\hline Speurlchen & 36 & \multicolumn{4}{|c|}{6 Spiecheingerchen } & $26 s$ & \multicolumn{3}{|c|}{ Stragelchen } & 34 & \multicolumn{3}{|c|}{4 Sutterchen } & 1 & \multicolumn{2}{|c|}{ Tengelein } & 1 \\
\hline Speurlechen & 1 & \multicolumn{4}{|c|}{ Spiecheingerlein } & $18 s$ & \multicolumn{3}{|c|}{ Strägelchen } & 3 & Sutte & reich & en & $36^{\prime}$ & Ten & ngelchen & 45 \\
\hline Speurlein & 14 & & iecheingle & ein & & $2 \mathrm{~S}$ & Stra & gele & & 7 & Sutte & reier & chen & 1 & Ten & ngelein & 4 \\
\hline Speurllein & 1 & & iecheinige & erch & nen & $2 \mathrm{~S}$ & Stra & gell & ein & 3 & Sutte & reile & & 11 & & & \\
\hline & & & iecheinige & erlei & & $3 \mathrm{~S}$ & Strą & glei & & 1 & Sutze & ereicl & hen & 1 & & & \\
\hline & & & & & & & Strä & glei & & 1 & Sütte & reich & nen & 1 & & & \\
\hline & & & & & & & & & & & Sütte & rrlein & & 1 & & & \\
\hline Triesche & & & Tschac & hen & & & & oerk & aules & & & Unbr & reuke & & & Ungich & \\
\hline chen & & $1 \mathrm{cl}$ & hen & & 10 & cher & & & & & 3 lein & & & 14 & elei & & 1 \\
\hline lein & & & ein & & & 5 lein & & & & & $2 \mathrm{Unb}$ & reike & lein & 1 & cher & & 1 \\
\hline Trieschelche & & $7 \mathrm{~T}$ & schachche & & 2 & Übe & erka & aulc & hen & & 9 Unb & reukc & chen & 8 & lein & & 12 \\
\hline Trieschelein & & $4 \mathrm{~T}$ & schächche & & 2 & Übe & erkä & äulc & hen & & $7 \mathrm{Unb}$ & reuke & echen & 3 & Ung & gichchen & 7 \\
\hline Trieschelleiı & & $4 \mathrm{~T}$ & schachelc & hen & 1 & Übe & erka & aule & & & 3 Unb & oreuke & elein & 31 & Ung & gichelein & 4 \\
\hline Trieschlein & & $2 \mathrm{~T}$ & schächelc & hen & 2 & Übe & erka & aule & nche & n 3 & 0 Unb & reukl & lein & 7 & Ung & gichen & 4 \\
\hline Trischelchen & & $2 \mathrm{~T}$ & schachele & & 1 & Übe & erka & aule & nlein & & 2 Unk & rreuke & elein & 1 & Ung & gichlein & 35 \\
\hline Trischelein & & $1 \mathrm{~T}$ & Schacheno & then & 19 & & & & & & Unk & rreukl & lein & 1 & Üng & gchen & 1 \\
\hline & & & Schachenl & ein & 21 & & & & & & & & & & Üng & gelchen & 1 \\
\hline & & & schachleiı & & 2 & 2 & & & & & & & & & & & \\
\hline & & & schächleiı & & 3 & 3 & & & & & & & & & & & \\
\hline Vatzel & & & Viefeicl & & & & Vil & & & & Jorme & eusen & & & & eumerat & \\
\hline chen & 12 & leir & & & 15 & chen & & & $5 \mathrm{cl}$ & hen & & & 11 & cher & & & 11 \\
\hline lein & 3 & Vie & efeichcher & & 3 & Villc & ches & & $501 \mathrm{e}$ & in & & & 3 & lein & & & 4 \\
\hline Vatzelchen & 38 & Vie & efeichelch & nen & 4 & Ville & ein & & $1 \mathrm{~V}$ & orm & leusch & nen & 10 & Wei & ime & ratchen & 2 \\
\hline Vätzelchen & 5 & Vie & efeichelei & & 34 & & & & & orm & eusec & chen & 1 & Wel & ume & eratchen & 38 \\
\hline Vatzelein & 4 & Vie & efeichlein & & 11 & & & & & orm & eusel & chen & 1 & Wel & ume & erätchen & 5 \\
\hline Vatzellein & 2 & & & & & & & & & orm & eusel & ein & 3 & Wel & ume & eratlein & 7 \\
\hline Vatzlein & 1 & & & & & & & & & orm & eusen & hchen & 26 & & & & \\
\hline & & & & & & & & & & orm & eusen & alein & 5 & & & & \\
\hline & & & & & & & & & & orme & eusle & & 4 & & & & \\
\hline Wommu & & & Wug & & & Zeime & & & & Zentr & rieg & & Zeu & ulel & & Ziek & \\
\hline chen & & & chen & & chen & & & & chen & & & $6 \mathrm{cl}$ & hen & & & chen & 5 \\
\hline lein & & 10 & lein & 61 & lein & & & & ein & & & 9 le & in & & & lein & 10 \\
\hline Wommuchche & & 13 & Wugchen & 242 & Zeim & nelche & & 382 & Zentri & legch & & $28 Z$ & eulche & & & Ziekchen & 22 \\
\hline Wommuchelc & hen & & Wugelein & 12 & Zeim & nelein & & 102 & Zentri & iegelc & chen & $2 Z$ & eulelcl & hen & 412 & Zieklein & 27 \\
\hline Wommuchele & & 1 & Wuglein & 162 & Zeim & nellei & & 32 & Zentri & ieglei & & $19 Z$ & eulelei & & 8 & & \\
\hline Wommuchen & & 1 & Wügchen & 4 & & & & & & & & & eulelle & & 2 & & \\
\hline Wommuchlei & & 26 & Wüglein & 5 & & & & & & & & & & & & & \\
\hline Wommüchche & & 1 & & & & & & & & & & & & & & & \\
\hline Wommüchelc & hen & 1 & & & & & & & & & & & & & & & \\
\hline Wommüchlei & & 4 & & & & & & & & & & & & & & & \\
\hline
\end{tabular}




\begin{tabular}{|c|c|c|c|c|c|c|c|c|c|c|c|}
\hline \multicolumn{3}{|c|}{ Arbeitesrehzeiner } & \multicolumn{4}{|c|}{ Drachenaufwerlützel } & \multicolumn{3}{|c|}{ Elfenquestarl } & & \\
\hline \multicolumn{2}{|c|}{ Arbeitesehzeinerchen } & 1 & \multicolumn{3}{|l|}{ chen } & 16 & \multicolumn{3}{|l|}{ chen } & 12 & \\
\hline \multicolumn{2}{|l|}{ Arbeitesreheinerchen } & 1 & \multicolumn{3}{|c|}{ Drachenaufwerlutzelein } & 1 & \multicolumn{3}{|l|}{ lein } & 5 & \\
\hline \multicolumn{2}{|l|}{ Arbeitesrehzeinchen } & 1 & \multicolumn{3}{|c|}{ Drachenaufwerlützelchen } & 34 & \multicolumn{3}{|c|}{ Elfenquestarchen } & 1 & \\
\hline \multicolumn{2}{|c|}{ Arbeitesrehzeinerchen } & 18 & \multicolumn{3}{|c|}{ Drachenaufwerlützelein } & 5 & \multicolumn{3}{|c|}{ Elfenquestarlchen } & 34 & \\
\hline \multicolumn{2}{|c|}{ Arbeitesrehzeinerlein } & 21 & \multicolumn{3}{|c|}{ Drachenaufwerlützellein } & 3 & \multicolumn{3}{|c|}{ Elfenquestärlchen } & 2 & \\
\hline \multicolumn{2}{|l|}{ Arbeitesrehzeinerlin } & 1 & \multicolumn{3}{|c|}{ Drachenauwerlützelchen } & 1 & \multicolumn{3}{|c|}{ Elfenquestarlein } & 7 & \\
\hline \multicolumn{2}{|l|}{ Arbeitsrehzeinerchen } & 3 & \multicolumn{3}{|c|}{ Drachensufwerlützelchen } & 1 & \multicolumn{3}{|c|}{ Elfenquestarllein } & 2 & \\
\hline \multicolumn{2}{|l|}{ Arbeitsrehzeinerlein } & 2 & \multicolumn{3}{|l|}{ lein } & 1 & & & \\
\hline \multicolumn{2}{|l|}{ chen } & 10 & \multicolumn{3}{|c|}{0} & & & & & & \\
\hline \multicolumn{2}{|l|}{ lein } & \multicolumn{4}{|l|}{7} & & & & & & \\
\hline \multicolumn{2}{|l|}{ Entzauberhaub } & & Jubeldauhang & & & Kinc & desubach & & & Puppenbüble & \\
\hline chen & 9 & chei & & 7 & chen & & & & cher & & 9 \\
\hline Entzauberhaubchen & 21. & Jub & eldauhangchen & 19 & Kinde & esub & achchen & 15 & lein & & 6 \\
\hline Entzauberhäubchen & 14. & Jub & eldauhängchen & 6 & Kinde & esub & ächelchen & & Pup & penbübchen & 3 \\
\hline Entzauberhaublein & 10 & Jub & eldauhangelchen & 1 & Kinde & esub & ächelein & 1 & Pup & penbübelchen & 6 \\
\hline Entzauberhäublein & 3. & Jub & eldauhangelein & 1 & Kinde & esub & achen & 1 & Pup & penbübelein & 1 \\
\hline lein & 8. & Jub & eldauhängerchen & 1. & Kinde & esub & achlein & 20 & Pup & penbüblchen & 4 \\
\hline & & Jub & eldauhanglein & 12 & Kinde & esub & ächlein & 10 & Pup & penbüblechen & 10 \\
\hline & & Jub & eldauhänglein & 4 & lein & & & 9 & Pup & penbüblein & 11 \\
\hline & & Jub & eldauhngchen & 1 & & & & & Pup & penbüblelein & 10 \\
\hline & & Jub & elfauhängchen & 1 & & & & & Püp & penbüblein & 1 \\
\hline & & lein & & 9 & & & & & & & \\
\hline
\end{tabular}




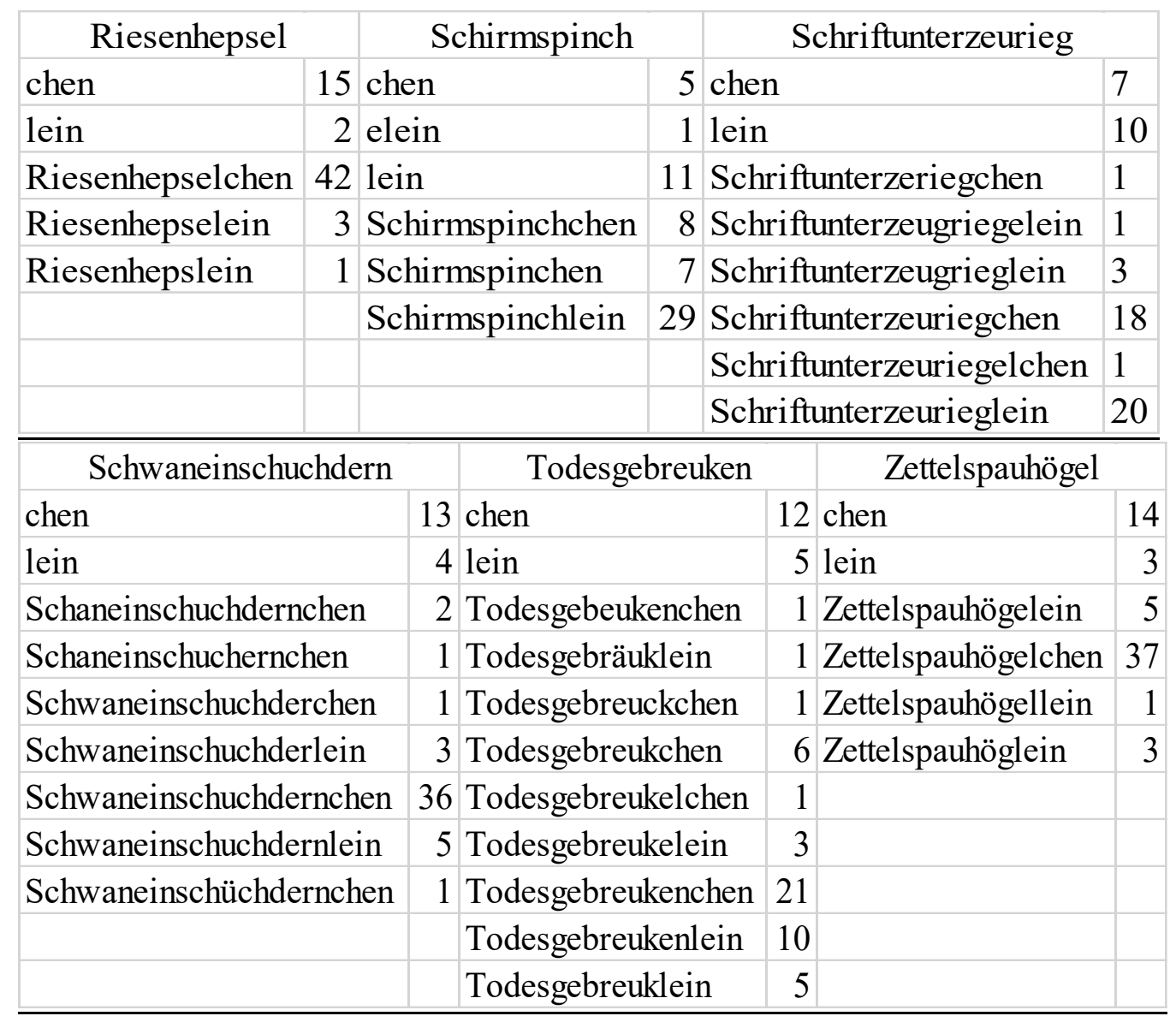

Magyar

\begin{tabular}{|c|c|c|c|c|c|c|c|c|c|}
\hline \multicolumn{2}{|l|}{ adandzsú } & \multicolumn{2}{|l|}{ banyódok } & \multicolumn{2}{|l|}{ bicsó } & \multicolumn{2}{|l|}{ budzag } & \multicolumn{2}{|l|}{ csülgö } \\
\hline adandzsúcska & 175 & acska & 1 & bicsócska & 72 & budzagacska & 5 & acska & 1 \\
\hline adandzsúka & 52 & banyódacska & 1 & bicsóka & 169 & budzagcsa & 1 & cske & 24 \\
\hline cska & 26 & banyódikocska & 1 & bicsu & 1 & budzagcska & 1 & csülgőcska & 1 \\
\hline $\mathrm{ka}$ & 12 & banyódka & 6 & cska & 19 & budzagka & 24 & csülgöcske & 1 \\
\hline ocska & 1 & banyódocska & 18 & ka & 18 & budzagocska & 205 & csülgőcske & 165 \\
\hline & & banyódokacska & 5 & kó & 1 & budzagöcske & 1 & csülgôka & 1 \\
\hline & & banyódokcska & 3 & & & cska & 1 & csülgóke & 70 \\
\hline & & banyódokcske & 1 & & & ka & 5 & ke & 12 \\
\hline & & banyódokka & 8 & & & ocska & 35 & kó & 1 \\
\hline & & banyodokocska & 3 & & & & & & \\
\hline & & banyódokocska & 188 & & & & & & \\
\hline & & banyódoköcske & 1 & & & & & & \\
\hline & & cska & 2 & & & & & & \\
\hline & & ka & 4 & & & & & & \\
\hline & & kó & 1 & & & & & & \\
\hline & & ocska & 30 & & & & & & \\
\hline & & öcske & 1 & & & & & & \\
\hline
\end{tabular}




\begin{tabular}{|c|c|c|c|c|c|c|c|c|c|c|}
\hline \multicolumn{2}{|l|}{ dínür } & \multicolumn{3}{|c|}{ ekresz } & \multicolumn{2}{|l|}{ farány } & \multicolumn{2}{|l|}{ féj } & \multicolumn{2}{|l|}{ felkezárd } \\
\hline cska & 1 & \multicolumn{2}{|c|}{ cske } & 1 & cske & 1 & acska & $26 a$ & acska & 1 \\
\hline dinürecske & 1 & \multicolumn{2}{|c|}{ ecske } & 211 & farányacska & 1 & ecske & $26 \mathrm{f}$ & felkezárdacska & 8 \\
\hline dínürecske & 2 & \multicolumn{2}{|c|}{ ekreszecske } & 511 & farányka & 183 & féjacska & $9 \mathrm{f}$ & felkezárdka & 68 \\
\hline dinürka & 1 & \multicolumn{2}{|c|}{ ekreszke } & 185 & fárányka & 1 & féjácska & $1 \mathrm{f}$ & felkezárdocska & 155 \\
\hline dinürke & 14 & \multicolumn{2}{|c|}{ ekreszocska } & 21 & farányocska & 55 & féjcske & $1 \mathrm{k}$ & ka & 8 \\
\hline dinürke & 1 & \multicolumn{2}{|c|}{ ekreszöcske } & 11 & $\mathrm{ka}$ & 27 & féjecska & $1 \mathrm{c}$ & ocska & 28 \\
\hline dínürke & 154 & \multicolumn{2}{|l|}{ ke } & 16 & ocska & 11 & féjecske & 150 & & \\
\hline dínürke & 6 & \multicolumn{2}{|l|}{ kó } & 1 & 1 & & féjécske & 1 & & \\
\hline dínürocska & 2 & \multicolumn{2}{|c|}{2} & & & & féjecskje & 1 & & \\
\hline dinüröcske & 4 & \multicolumn{2}{|c|}{4} & & & féjike & 1 & & \\
\hline dinüröcske & 3 & \multicolumn{2}{|c|}{3} & & & & féjka & 1 & & \\
\hline dínüröcske & 52 & & & & & & féjke & 72 & & \\
\hline dínürőcske & 1 & & & & & & féjocska & 3 & & \\
\hline dínüröcske & 1 & & & & & & féjöcske & 2 & & \\
\hline ke & 20 & & & & & & ke & 12 & & \\
\hline kó & 1 & & & & & & & & & \\
\hline ocska & 1 & & & & & & & & & \\
\hline öcske & 15 & & & & & & & & & \\
\hline fiszők & üm & & fracsi & & gonú & & hém & & hosztob & \\
\hline ecske & & 1 & cska & & 13 cska & 23 & ecske & 26 & hosztobácska & 2 \\
\hline fiszzőkümöc & ske & 1 & fracsicska & & 32 gonúcska & 155 & hémcske & 1 & hosztobka & 108 \\
\hline fiszőkümcs & & 3 & fracsícska & & 1 gonúcske & 2 & hémecske & 170 & hosztobocska & 128 \\
\hline fisszőkümec & ske & 6 & fracsika & 20 & 01 gonúka & 76 & hémicske & 1 & $\mathrm{ka}$ & 12 \\
\hline fiszőkümics & & 1 & fracska & & 1 gonúke & 3 & hémike & 1 & ocska & 27 \\
\hline fiszőkümka & & 2 & francsika & & $3 \mathrm{ka}$ & 16 & hémke & 65 & & \\
\hline fiszökümke & & 1 & $\mathrm{ka}$ & & 25 & & hémocska & 3 & & \\
\hline fiszőkümke & & 76 & & & & & hémöcske & 1 & & \\
\hline fiszőkümoc & ska & 1 & & & & & ke & 13 & & \\
\hline fiszzőkümoc & ske & 1 & & & & & & & & \\
\hline fiszzőümöc & ske & 134 & & & & & & & & \\
\hline fiszőkümőc & ske & 1 & & & & & & & & \\
\hline ke & & 9 & & & & & & & & \\
\hline ocske & & 1 & & & & & & & & \\
\hline öcske & & 27 & & & & & & & & \\
\hline
\end{tabular}




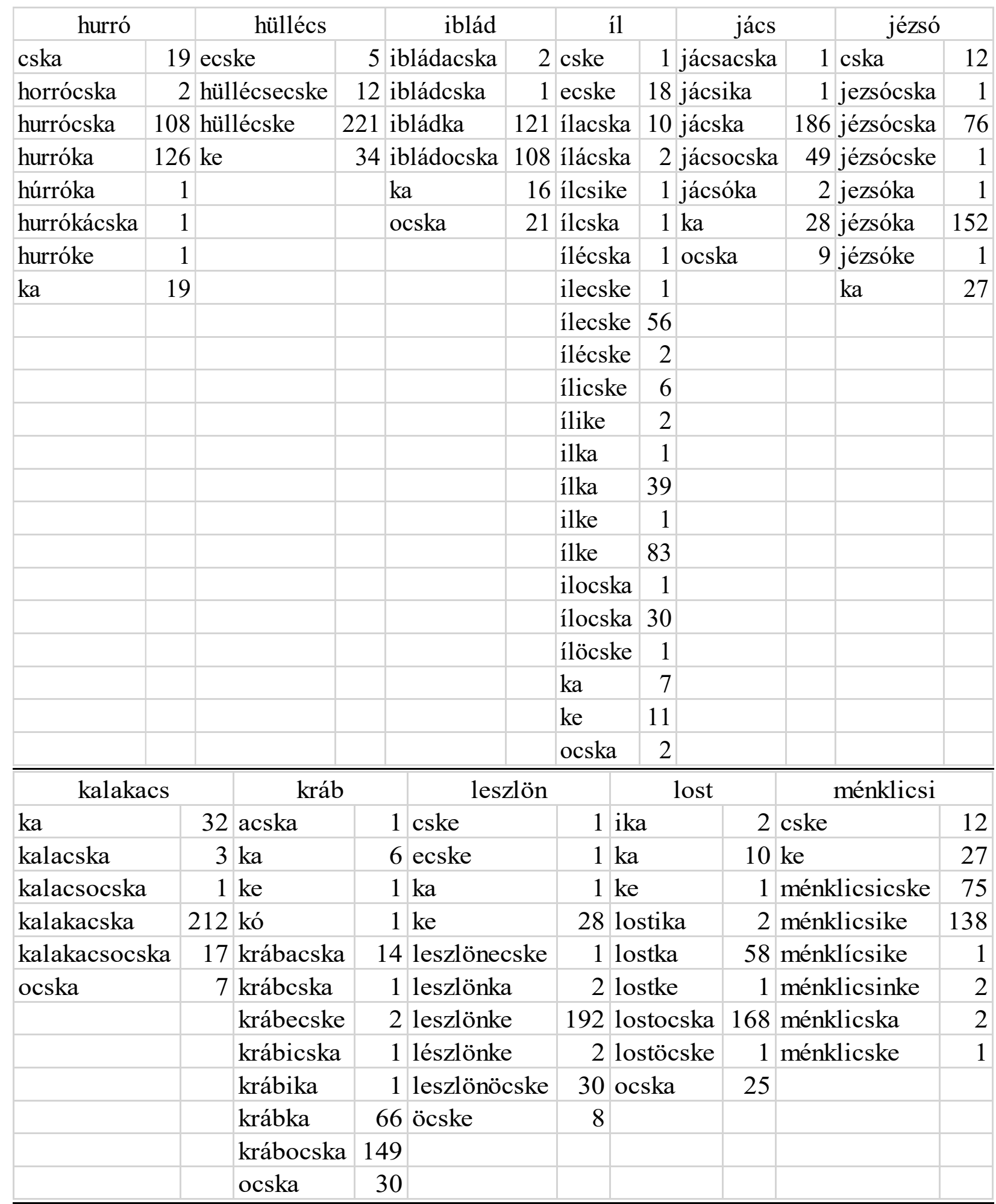




\begin{tabular}{|c|c|c|c|c|c|c|c|c|c|}
\hline muliz & \multicolumn{3}{|c|}{ nánoncs } & nyöfögü & & \multicolumn{2}{|l|}{ oladrangy } & \multicolumn{2}{|l|}{ ökötty } \\
\hline $\mathrm{ka}$ & \multicolumn{2}{|l|}{$\mathrm{ka}$} & $28 \mathrm{cs}$ & cske & \multicolumn{2}{|l|}{$\mathrm{ka}$} & & 6 ecske & 1 \\
\hline mulizecske & \multicolumn{2}{|l|}{ kó } & & ke & $9 \mathrm{ke}$ & ke & 16 & $6 \mathrm{ke}$ & 23 \\
\hline mulizka & \multicolumn{2}{|c|}{ nánocska } & 38 ny & nyöfögücska & \multicolumn{2}{|c|}{ ocska } & 22 & 2 öcske & 13 \\
\hline mulízka & \multicolumn{2}{|c|}{ nánocsocska } & \multicolumn{2}{|c|}{ nyöfögücske } & \multicolumn{2}{|c|}{ oladrangyacska } & 2 & 2 ököttycske & 4 \\
\hline mulizke & \multicolumn{2}{|c|}{ nánoncsika } & 1 ny & nyöfögücske 17 & \multicolumn{2}{|r|}{ oladrangyka } & 93 & 3 ököttyecske & 2 \\
\hline mulizocska 30 & \multicolumn{2}{|c|}{ nánoncska } & 166 ny & nyöfögúke & 48 ola & oladrangyocska & 115 & 5 ököttyke & 169 \\
\hline \multirow[t]{3}{*}{ ocska } & \multicolumn{2}{|c|}{ nánoncsocska } & 24 & & \multicolumn{2}{|c|}{ oladranyocska } & & 3 ököttyöcske & 44 \\
\hline & \multicolumn{2}{|c|}{ ocska } & 9 & & & & & ököttyücske & 4 \\
\hline & & & & & & & & ököttyüke & 1 \\
\hline parádzsi & & pirgüc & & polyúh & & racsu & & retenyép & \\
\hline cska & $15 \mathrm{k}$ & ke & $28 \mathrm{c}$ & cska & $1 \mathrm{cs}$ & cska & $14 \epsilon$ & ecske & 18 \\
\hline cske & $15 \dot{c}$ & öcske & $10 \mathrm{k}$ & ka & $11 \mathrm{ka}$ & $\mathrm{ka}$ & 241 & ke & 20 \\
\hline $\mathrm{ka}$ & $20 \mathrm{p}$ & pirgücecske & 10 & ocska & $23 \mathrm{ra}$ & racsucska & 751 & retenyépcske & 1 \\
\hline kó & $1 \mathrm{p}$ & pirgücike & 10 & ocske & $2 \mathrm{ra}$ & racsúcska & 11 & retenyépecska & 1 \\
\hline parádzsicsika & $1 \mathrm{p}$ & pirgücka & $1 \mathrm{p}$ & polyúcska & $2 \mathrm{ra}$ & racsuka & $150 \mathrm{r}$ & retenyepecske & 1 \\
\hline parádzsicska & $82 \mathrm{r}$ & pirgücke & $201 \mathrm{p}$ & polyúhacska & $1 \mathrm{ra}$ & racsukácska & $1 \mathrm{r}$ & retenyépecske & 110 \\
\hline parádzsicske & $4 \mathrm{p}$ & pírgücke & $1 \mathrm{p}$ & polyúhácska & 1 & & & retenyépécske & 2 \\
\hline parádzsika & $131 \mathrm{r}$ & pirgücöcske & $22 \mathrm{p}$ & polyúhcska & 12 & & & retenyépike & 1 \\
\hline parádzsike & 3 & & & polyúhcske & 1 & & & retenyépke & 111 \\
\hline parádzska & 1 & & & polyúhka & 66 & & & retényépke & 1 \\
\hline & & & & polyúhocska 1 & 143 & & & & \\
\hline & & & & polyúka & 2 & & & & \\
\hline rogyáta & & röcsü & & sáhas & & szödi & & tejögöl & \\
\hline ácska & 13 & cske & 15 & 5 ika & & 2 cske & 12 & ecske & 1 \\
\hline cska & 17 & ke & 21 & $\mathrm{ka}$ & 25 & $5 \mathrm{ke}$ & 26 & ke & 30 \\
\hline $\mathrm{ka}$ & 3 & röcsücske & 62 & ocska & 10 & 0 szödicske & 56 & öcske & 7 \\
\hline rágyátácska & 3 & röcsücske & 2 & 2 sáhacsocska & & 1 szödike & 171 & tejöglöcske & 2 \\
\hline rogyágatácska & 1 & röcsüke & 161 & sáhasacska & & 7 szödíke & 1 & tejögölcske & 2 \\
\hline rogyatácska & 1 & röcsúke & 1 & sáhaska & 187 & & & tejögölecske & 1 \\
\hline rogyátacska & 34 & röcsükécske & 1 & sáhaskácska & & 1 & & tejögölike & 1 \\
\hline rogyátácska & 179 & & & sáhasocska & 34 & 4 & & tejögölke & 178 \\
\hline rogyátaka & 2 & & & & & & & tejögölöcske & 41 \\
\hline rogyátka & 6 & & & & & & & & \\
\hline rogyátocska & 7 & & & & & & & & \\
\hline
\end{tabular}




\begin{tabular}{|c|c|c|c|c|c|c|c|c|c|}
\hline \multicolumn{2}{|l|}{ tipe } & \multicolumn{2}{|l|}{ tumalázs } & \multicolumn{2}{|l|}{ tyemi } & \multicolumn{2}{|l|}{ vébaly } & \multicolumn{2}{|l|}{ vocs } \\
\hline cske & 29 & ika & 2 & cske & 13 & ácska & 1 & ácska & 1 \\
\hline ke & 3 & ka & 22 & ke & 26 & ka & 23 & ika & 2 \\
\hline ocska & 1 & ocska & 15 & tyemicske & 69 & ocska & 15 & ka & 24 \\
\hline tipecska & 4 & tumalázsacska & 4 & tyemike & 159 & vébajka & 1 & ocska & 12 \\
\hline tipecske & 141 & tumalázska & 148 & tyemikécske & 1 & vébalyacska & 2 & vocsácska & 1 \\
\hline tipécske & 72 & tumalázsocska & 68 & & & vébalyka & 168 & vocsika & 2 \\
\hline tipeke & 11 & & & & & vébalyocska & 49 & vocska & 149 \\
\hline tipéke & 1 & & & & & vébályocska & 2 & vocskácska & 1 \\
\hline tiperecske & 1 & & & & & & & vocske & 2 \\
\hline tipike & 1 & & & & & & & vocsocska & 74 \\
\hline
\end{tabular}

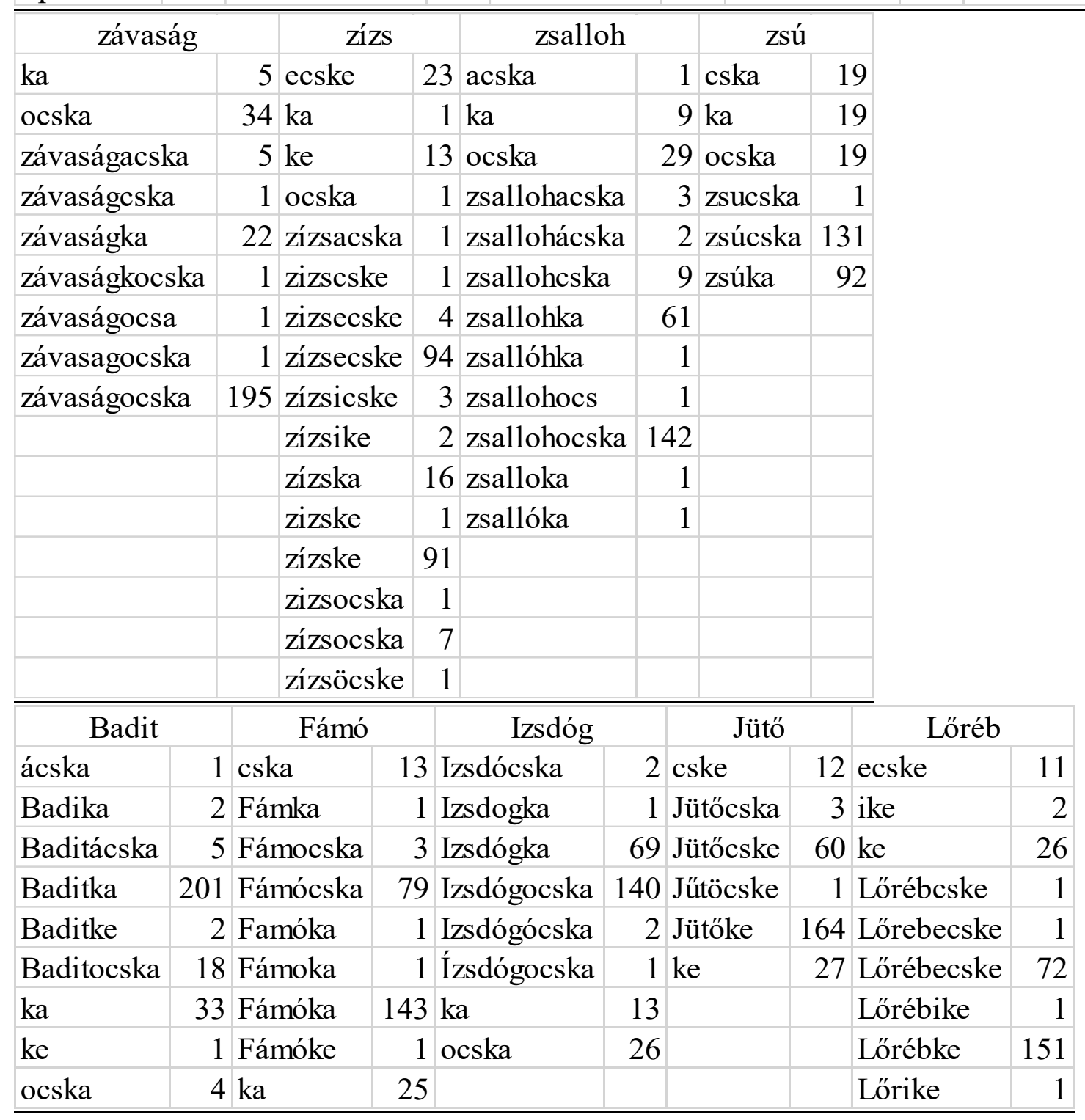




\begin{tabular}{|c|c|c|c|c|c|}
\hline \multicolumn{2}{|c|}{$\begin{array}{c}\text { A naplopó } \\
\text { (szelég) } \\
\text { mindig csak azt várja, } \\
\text { hogy a szájába } \\
\text { repüljön a sült galamb. }\end{array}$} & \multicolumn{2}{|c|}{$\begin{array}{c}\text { És te, drága } \\
\text { (tolámb), } \\
\text { azt hiszed, minden } \\
\text { időmet neked fogom } \\
\text { szentelni? }\end{array}$} & \multicolumn{2}{|c|}{$\begin{array}{c}\text { A két fiatal kis } \\
\text { (salagáty) } \\
\text { már megint nem bírt } \\
\text { magával az éjjel. }\end{array}$} \\
\hline ecske & 6 & ka & 2 & $\mathrm{ka}$ & 4 \\
\hline ke & 2 & ocska & 5 & ocska & 3 \\
\hline szelegecske & 3 & ocskám & 2 & salagátyacska & 1 \\
\hline szelégecske & 179 & tolámbacska & 4 & salagátyácska & 1 \\
\hline szelegke & 1 & tolámbika & 2 & salagátycska & 1 \\
\hline szelégke & 73 & tolambka & 1 & salagátyinka & 2 \\
\hline \multirow[t]{6}{*}{ szelégocska } & 1 & tolámbka & 92 & salagátyka & 142 \\
\hline & & tolámbkám & 7 & salagátyocsa & 1 \\
\hline & & tolambocska & 1 & salagatyocska & 1 \\
\hline & & tolámbocska & 129 & salagátyocska & 100 \\
\hline & & tolámbocskám & 18 & salagátyocska & 1 \\
\hline & & tolámocska & 3 & & \\
\hline \multicolumn{2}{|c|}{$\begin{array}{l}\text { Ó, most látom, mibe } \\
\text { kevert engem ez a } \\
\text { szélhámos }\end{array}$} & \multicolumn{2}{|c|}{$\begin{array}{l}\text { Minden rátarti } \\
\text { (csirpó) } \\
\text { tökéletesnek hiszi } \\
\text { magát. }\end{array}$} & & \\
\hline $\mathrm{ka}$ & 4 & csirpócska & 109 & & \\
\hline ocska & 3 & csirpoka & 1 & & \\
\hline zsalagódka & 11 & csirpóka & 130 & & \\
\hline zsalagódocska & 18 & csirpokocska & 1 & & \\
\hline zsalodógocska & 2 & csirpókocska & 9 & & \\
\hline zsalódogocska & 1 & cska & 5 & & \\
\hline zsalogócska & 1 & ka & 3 & & \\
\hline zsalogódcska & 1 & & & & \\
\hline zsalogódicska & 1 & & & & \\
\hline zsalogódika & 1 & & & & \\
\hline zsalogodka & 2 & & & & \\
\hline zsalogódka & 96 & & & & \\
\hline zsalogodocska & 1 & & & & \\
\hline zsalogódocska & 106 & & & & \\
\hline zsalógodocska & 1 & & & & \\
\hline zsalógódocska & 1 & & & & \\
\hline
\end{tabular}

